\title{
Hydrology and Water Quality in the Green River and Surrounding Agricultural Areas near Green River in Emery and Grand Counties, Utah, 2004-05
}

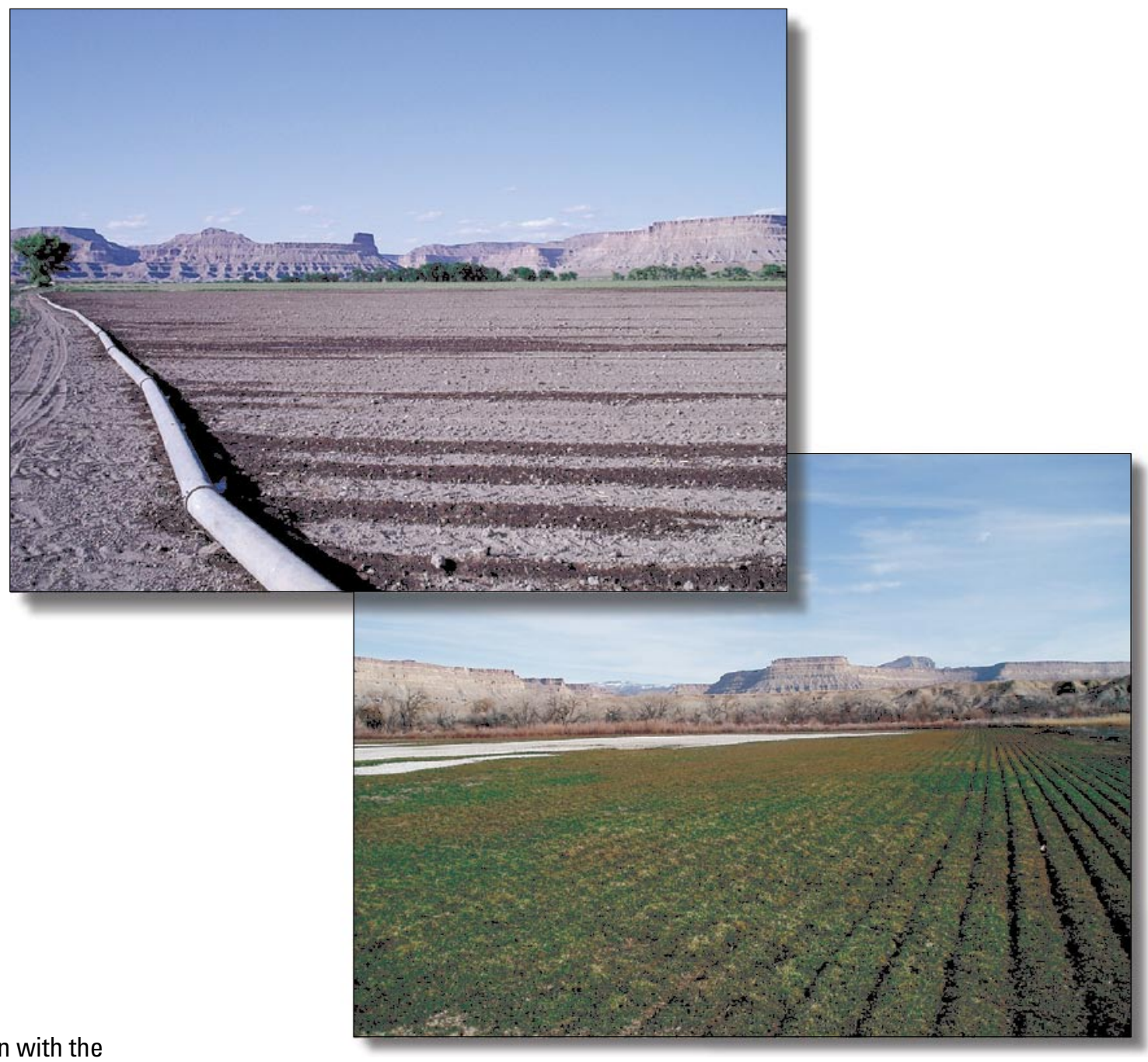

Scientific Investigations Report 2006-5186

U.S. Department of the Interior U.S. Geological Survey 
Cover photo: Agricultural areas near Green River, Utah. (Photographs by Steven Gerner.) 


\section{Hydrology and Water Quality in the Green River and Surrounding Agricultural Areas near Green River in Emery and Grand Counties, Utah, 2004-05}

By S.J. Gerner, L.E. Spangler, B.A. Kimball, D.E. Wilberg, and D.L. Naftz

Scientific Investigations Report 2006-5186

Prepared in cooperation with the

NATURAL RESOURCES CONSERVATION SERVICE

U.S. Department of the Interior

U.S. Geological Survey 


\section{U.S. Department of the Interior \\ Dirk Kempthorne, Secretary}

\section{U.S. Geological Survey \\ P. Patrick Leahy, Acting Director}

Reston, Virginia: 2006

For additional information write to:

U.S. Geological Survey

Director, USGS Utah Water Science Center

2329 W. Orton Circle

Salt Lake City, UT 84119-2047

Email: GS-W-UTpublic-info@usgs.gov

URL: http://ut.water.usgs.gov/

For more information about the USGS and its products:

Telephone: 1-888-ASK-USGS

World Wide Web: http://www.usgs.gov/

Any use of trade, firm, or product names is for descriptive purposes only and does not imply endorsement by the U.S. Government.

Although this report is in the public domain, permission must be secured from the individual copyright owners to reproduce any copyrighted materials contained within this report. 


\section{Contents}

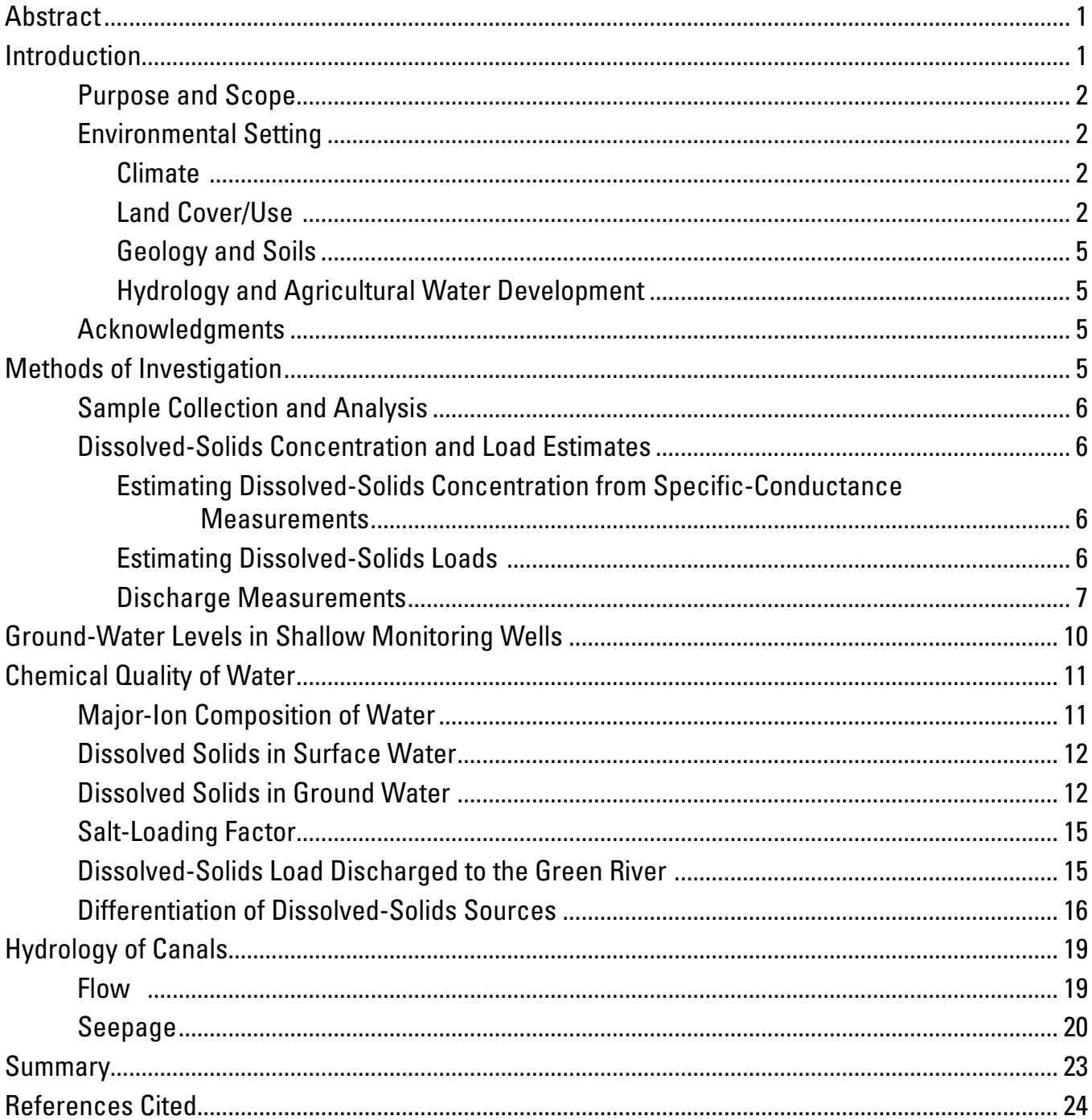

\section{Figures}

Figure 1. Geographic features and water-quality monitoring sites in the Green River study area, Emery and Grand Counties, Utah. ................................................................................. 3

Figure 2. (A) Land cover/use and (B) geology of the Green River study area, Utah............................ 4

Figure 3. (A) The Acoustic Doppler Current Profiler used to make the discharge measurements at (B) site GR-1 near Green River, Utah ........................................................................ 7

Figure 4. Water levels in monitoring wells near Green River, Utah............................................................... 11

Figure 5. Relative composition of water samples collected from the Green River study area,

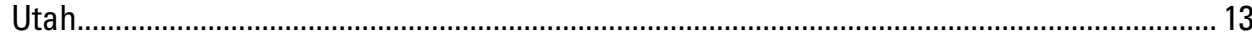

Figure 6. Distribution of dissolved-solids concentration and load, and discharge, in waters of the Green River study area, Utah 
Figure 7. Seeps at site SP-4 along the western bank of the Green River (looking downstream) adjacent to agricultural fields near Green River, Utah, August 2004.

Figure 8. Variation of $\delta^{87} \mathrm{Sr}$ with strontium concentration in samples collected from selected water-quality monitoring sites near Green River, Utah...

Figure 9. Variation of $\delta^{11} \mathrm{~B}$ with boron concentration in samples collected from selected water-quality monitoring sites near Green River, Utah...................................................... 19

Figure 10. Daily mean discharge in the Thayn Canal, June 2, 2003, to October 31, 2004................... 21

Figure 11. Sites where discharge was measured on the Thayn and Green River Canals near Green River, Utah, during June 20-23, 2005.

Figure 12. Stage in Thayn and Green River Canals, June 20-23, 2005. .............................................. 23

\section{Tables}

Table 1. Site characteristics and summary of dissolved-solids concentration and load for waterquality monitoring sites near Green River, Utah, March 2004 to May 2005.

Table 2. Properties of water samples collected from water-quality monitoring sites near Green River, Utah.

Table 3. Concentration of major ions in water samples collected from water-quality monitoring sites near Green River, Utah

Table 4. Field and analytical methods and minimum reporting levels for water-quality field measurements and constituent concentrations in samples collected from waterquality monitoring sites near Green River, Utah..

Table 5. Relative percentage of major ions in water samples collected at selected sites near Green River, Utah

Table 6. Discharge and dissolved-solids concentration at selected water-quality monitoring sites used in the calculation of a salt-loading factor for the Green River study area, Utah

Table 7. Discharge and dissolved-solids concentration and load in the Green River at two sites and the difference in dissolved-solids load between those sites

Table 8. Dissolved-solids concentration in the Green River at two sites and the dissolvedsolids load discharging to the Green River in the reach between those sites.

Table 9. Estimated dissolved-solids load discharged to the Green River from the study area, June 1, 2004, to May 31, 2005

Table 10. Site characteristics, chemical concentration, isotope ratios, and specific conductance of samples collected from selected sites near Green River, Utah

Table 11. Stage and discharge measured in the Thayn, East Side, and Green River Canals near Green River, Utah.

Table 12. Estimated discharge during selected periods at the head of the Thayn, East Side, and Green River Canals near Green River, Utah

Table 13. Discharge, specific-conductance, and water temperature measurements made on the Thayn and Green River Canals near Green River, Utah-Continued

Table 14. Summary of gains or losses in discharge for specified reaches on the Green River Canal near Green River, Utah, June 22, 2005.

Table 15. Summary of gains or losses in discharge for specified reaches on the Thayn Canal near Green River, Utah, June 21, 2005

Table 16. Estimated seepage loss from the Thayn, East Side, and Green River Canals near Green River, Utah. 


\section{Conversion Factors, Datums, and Abbreviated Water-Quality Units}

\begin{tabular}{|c|c|c|}
\hline Multiply & By & To obtain \\
\hline \multicolumn{3}{|c|}{ Length } \\
\hline foot $(\mathrm{ft})$ & 0.3048 & meter $(\mathrm{m})$ \\
\hline mile (mi) & 1.609 & kilometer (km) \\
\hline inch (in.) & 2.54 & centimeter $(\mathrm{cm})$ \\
\hline \multicolumn{3}{|c|}{ Area } \\
\hline acre & 0.4047 & hectare (ha) \\
\hline acre & 0.004047 & square kilometer $\left(\mathrm{km}^{2}\right)$ \\
\hline square mile $\left(\mathrm{mi}^{2}\right)$ & 2.590 & square kilometer $\left(\mathrm{km}^{2}\right)$ \\
\hline \multicolumn{3}{|c|}{ Volume } \\
\hline acre-foot (acre-ft) & 1,233 & cubic meter $\left(\mathrm{m}^{3}\right)$ \\
\hline \multicolumn{3}{|c|}{ Flow rate } \\
\hline acre-foot per day (acre-ft/d) & 1,233 & cubic meter per day $\left(\mathrm{m}^{3} / \mathrm{d}\right)$ \\
\hline cubic foot per second $\left(\mathrm{ft}^{3} / \mathrm{s}\right)$ & 0.02832 & cubic meter per second $\left(\mathrm{m}^{3} / \mathrm{s}\right)$ \\
\hline inch per year (in/yr) & 2.54 & centimeter per year (cm/yr) \\
\hline gallon per minute (gal/min) & 3.785 & liter per minute $(\mathrm{L} / \mathrm{m})$ \\
\hline \multicolumn{3}{|c|}{ Mass } \\
\hline ton per day (ton/d) & 0.9072 & metric ton per day (ton/d) \\
\hline ton per year (ton/yr) & 0.9072 & metric ton per year (ton/yr) \\
\hline
\end{tabular}

Temperature in degrees Celsius $\left({ }^{\circ} \mathrm{C}\right)$ may be converted to degrees Fahrenheit $\left({ }^{\circ} \mathrm{F}\right)$ as follows:

$$
{ }^{\circ} \mathrm{F}=\left(1.8 \times{ }^{\circ} \mathrm{C}\right)+32 .
$$

Temperature in degrees Fahrenheit $\left({ }^{\circ} \mathrm{F}\right)$ may be converted to degrees Celsius $\left({ }^{\circ} \mathrm{C}\right)$ as follows:

$$
{ }^{\circ} \mathrm{C}=\left({ }^{\circ} \mathrm{F}-32\right) / 1.8 .
$$

Horizontal coordinate information is referenced to the North American Datum of 1983 (NAD 83). Vertical coordinate information is referenced to the National Geodetic Vertical Datum of 1929 (NGVD 29). Altitude, as used in this report, refers to distance above the vertical datum.

Specific conductance is reported in microsiemens per centimeter at 25 degrees Celsius $\left(\mu \mathrm{S} / \mathrm{cm}\right.$ at $\left.25^{\circ} \mathrm{C}\right)$. Concentrations of chemical constituents in water are reported either in milligrams per liter (mg/L), micrograms per liter $(\mu \mathrm{g} / \mathrm{L})$, or nanograms per liter $(\mathrm{ng} / \mathrm{L})$.

Isotopic ratios are reported in units of permil (per thousand). 


\title{
Hydrology and Water Quality in the Green River and Surrounding Agricultural Areas near Green River in Emery and Grand Counties, Utah, 2004-05
}

\author{
By S.J. Gerner, L.E. Spangler, B.A. Kimball, D.E. Wilberg, and D.L. Naftz
}

\section{Abstract}

Water from the Colorado River and its tributaries is used for municipal and industrial purposes by about 27 million people and irrigates nearly 4 million acres of land in the Western United States. Water users in the Upper Colorado River Basin consume water from the Colorado River and its tributaries, reducing the amount of water in the river. In addition, application of water to agricultural land within the basin in excess of crop needs can increase the transport of dissolved solids to the river. As a result, dissolved-solids concentrations in the Colorado River have increased, affecting downstream water users. During 2004-05, the U.S. Geological Survey, in cooperation with the Natural Resources Conservation Service, investigated the occurrence and distribution of dissolved solids in water from the agricultural areas near Green River, Utah, and in the adjacent reach of the Green River, a principal tributary of the Colorado River.

The flow-weighted concentration of dissolved solids diverted from the Green River for irrigation during 2004 and 2005 was 357 milligrams per liter and the mean concentration of water collected from seeps and drains where water was returning to the river during low-flow conditions was 4,170 milligrams per liter. The dissolved-solids concentration in water from the shallow part of the ground-water system ranged from 687 to 55,900 milligrams per liter.

Measurable amounts of dissolved solids discharging to the Green River are present almost exclusively along the river banks or near the mouths of dry washes that bisect the agricultural areas. The median dissolved-solids load in discharge from the 17 drains and seeps visited during the study was 0.35 ton per day. Seasonal estimates of the dissolved-solids load discharging from the study area ranged from 2,800 tons in the winter to 6,400 tons in the spring. The estimate of dissolved solids discharging from the study area annually is 15,700 tons.

Water samples collected from selected sites within the Green River agricultural areas were analyzed for naturally occurring isotopes of strontium and boron, which can be useful for differentiating dissolved-solids sources. Substantial variations in the delta strontium-87 ( $\left.\delta^{87} \mathrm{Sr}\right)$ and delta boron-11 $\left(\delta^{11} \mathrm{~B}\right)$ values among the sites were measured. Canal and river samples had relatively low concentrations of strontium and the most positive (heavier) isotopic ratios, while drains and seeps had a wide range of strontium concentrations and isotopic ratios that generally were less positive (lighter). Further study of the variation in strontium and boron concentrations and isotope ratios may provide a means to distinguish end members and discern processes affecting dissolved solids within the Green River study area; however, the results from isotope data collected during this study are inconclusive.

Flow and seepage losses were estimated for the three main canals in the study area for May 2 to October 4 in any given year. This period coincides with the frost-free period in the Green River area. Estimated diversion from the Green River into the Thayn, East Side, and Green River Canals is 6,600, 6,070, and 19,900 acre-feet, respectively. The estimated seepage loss to ground water from the Thayn, East Side, and Green River Canals during the same period is $1,550,1,460$, and 4,710 acre-feet, respectively.

\section{Introduction}

Water from the Colorado River and its tributaries is used for municipal and industrial purposes by about 27 million people and irrigates nearly 4 million acres of land in the Western United States (U.S. Department of the Interior, 2003). Water users in the Upper Colorado River Basin consume water from the Colorado River and its tributaries, reducing the amount of water in the river. In addition, application of water to agricultural land within the basin in excess of crop needs can increase the transport of dissolved solids to the river. As a result, dissolved-solids concentrations in the Colorado River have increased, affecting downstream water users.

In 1974, Congress enacted the Colorado River Basin Salinity Control Act, which authorizes the construction, operation, and maintenance of salinity control works in the Colorado River Basin. The U.S. Department of Agriculture (USDA) is a partner in the Colorado River Salinity Control Program, directing offices of the Natural Resources Conservation Service (NRCS) in the Upper Colorado River Basin to make reductions, where possible, in the dissolved-solids load to the Colorado River. The NRCS has been actively working to reduce dissolved-solids loads through promotion of improved irrigation methods. The term "dissolved solids" refers to the sum of the individual dissolved constituents present in water. This term is synonymous with "salinity." 
The agricultural lands surrounding the town of Green River in Emery and Grand Counties, Utah, have been identified by the NRCS as areas contributing dissolved solids to the Green River, which is a tributary of the Colorado River (fig. 1). Agricultural practices in the study area likely are contributing to the transport of dissolved solids to the Green River; however, little is known about the amount or relative contributions of dissolved solids from different sources. Estimates of the amount of dissolved solids discharged to the Green River that are attributable to agricultural lands in the area are needed by resource managers to assess the benefits that may be realized from irrigation system improvements. During 2004-05, the U.S. Geological Survey (USGS), in cooperation with the NRCS, conducted an investigation of the occurrence and distribution of dissolved solids in the Green River and in water from the agricultural areas near Green River, Utah.

\section{Purpose and Scope}

This report documents the methods used in, and results of, an evaluation to determine the amount of dissolved solids contributed to the Green River from agricultural lands near Green River, Utah. The report includes a description of the occurrence and distribution of dissolved solids in water sources in or near the agricultural lands near Green River, and descriptions and quantification of canal flow and canal seepage in the agricultural lands near Green River, Utah. The report also includes a discussion of the use of isotopes to evaluate the relative contributions of dissolved solids from irrigation and non-irrigation sources near Green River, Utah.

Chemical analysis of surface and ground water along with measurements of specific conductance and surface-water discharge were made at 38 water-quality monitoring sites between March 2004 and May 2005. An estimate of annual flow and seepage in major canals in the Green River, Utah, area was determined from discharge measurements and flow records.

\section{Environmental Setting}

The study area covers about $20 \mathrm{mi}^{2}$ along either side of the Green River upstream from the town of Green River, in east-central Utah (fig. 1). Settlement began in the late 1870s at Blake Station (now Green River), and since that time agriculture and ranching have been important to the Green River economy (Geary, 1996). Today, Green River is primarily a commercial farming and ranching community, and a hub for recreational activity on the Green River. The population of Green River, Utah, in 2000 was about 975.

The Green River flows generally south through the area and forms the boundary between Emery (to the west) and Grand Counties. The northern boundary of the study area is defined by the Book Cliffs (fig. 1), a prominent escarpment that trends generally east-west. South of the Book Cliffs, the terrain generally consists of flat to gently rolling lowlands into which the Green River is incised. Altitudes in the area range from about 4,060 $\mathrm{ft}$ along the Green River to about 5,200 $\mathrm{ft}$ on top of the Book Cliffs escarpment. Natural vegetation in the study area includes tamarisk, saltbrush, greasewood, and rabbit brush; cottonwoods and willows grow along the floodplain of the river.

\section{Climate}

Climate in the Green River area is temperate, with warm summers and generally mild winters. From 1893 through 2005 , temperatures ranged from a low of $-5.5^{\circ} \mathrm{C}$ in January to a high of $44.4^{\circ} \mathrm{C}$ in July; however, the annual mean temperature is $11.4^{\circ} \mathrm{C}$ (Western Regional Climate Center, 2005). On average, the frost-free period is 157 days from May 2 to October 4.

Mean annual precipitation in the Green River area as measured at Green River, Utah, is 6.33 in., with about equal amounts during the spring (1.55 in.) and summer (1.67 in.), and peaking in the fall (1.90 in.) (Western Regional Climate Center, 2005). Precipitation during June 2004 through May 2005 was about 8.4 in. Mean annual snowfall in the area is only about $7.8 \mathrm{in} / \mathrm{yr}$, with higher amounts on the Book Cliffs along the northern boundary of the area. Evaporation rates (May-October) in the study area are 40 to $44.9 \mathrm{in} / \mathrm{yr}$, substantially exceeding precipitation (Hemphill, 2005).

\section{Land Cover/Use}

Land-cover/use data were obtained from the National Land Cover Dataset (NLCD) (U.S. Geological Survey, 2006). This data set provides a consistent land-cover data layer for the conterminous United States and represents conditions in the early to mid-1990s. The area of agricultural land was adjusted by using data obtained from digital water-related land use maps (Utah State Division of Water Resources, written commun., 2006) representing conditions during 199798. Additionally, land brought into agricultural production between 1998 and 2004 was identified from National Agricultural Imagery Program ortho imagery (U.S. Department of Agriculture, 2006) and then digitized and merged with the previous data sets.

Irrigated lands in the Green River area extend primarily along the west side of the Green River for about $8 \mathrm{mi}$ north of the town. About 4,760 acres of land are considered agricultural in the study area (fig. 2). Predominant crop types include alfalfa (2,400 acres) and corn (990 acres). Fallow land, and land cultivated for grain, vegetables, and fruit (mostly melons) make up less than 300 total acres in the study area. About 600 acres of pasture are distributed along the river. Residential areas consist of about 1,600 acres of land mostly within the town limits of Green River. In addition, commercial/industrial areas make up about 265 acres that are almost entirely located southeast of, and across the river from, town. 

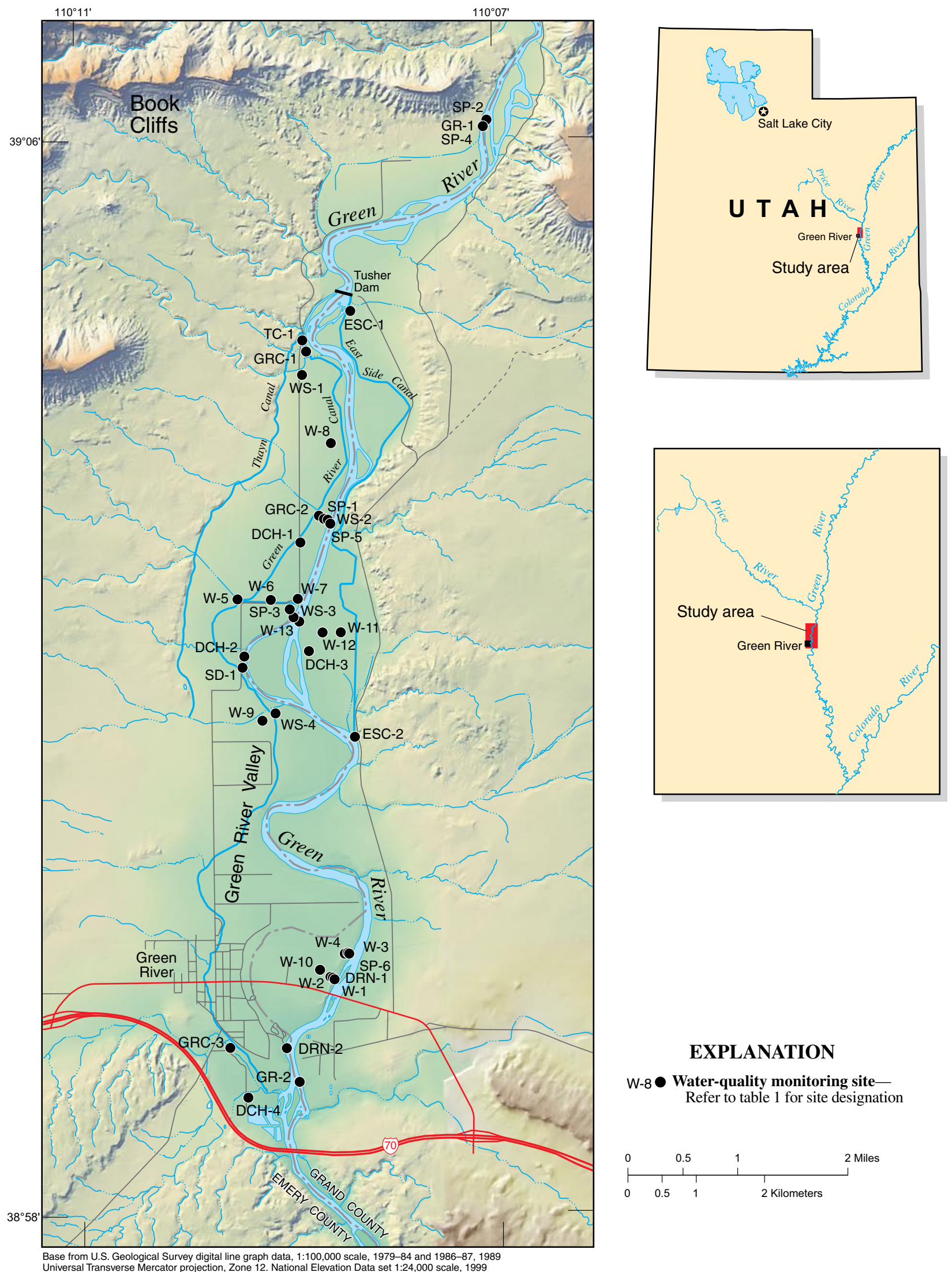

\section{EXPLANATION}

W-8 Water-quality monitoring siteRefer to table 1 for site designation

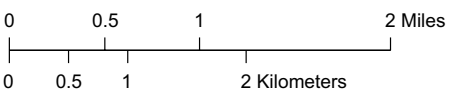

Figure 1. Geographic features and water-quality monitoring sites in the Green River study area, Emery and Grand Counties, Utah. 

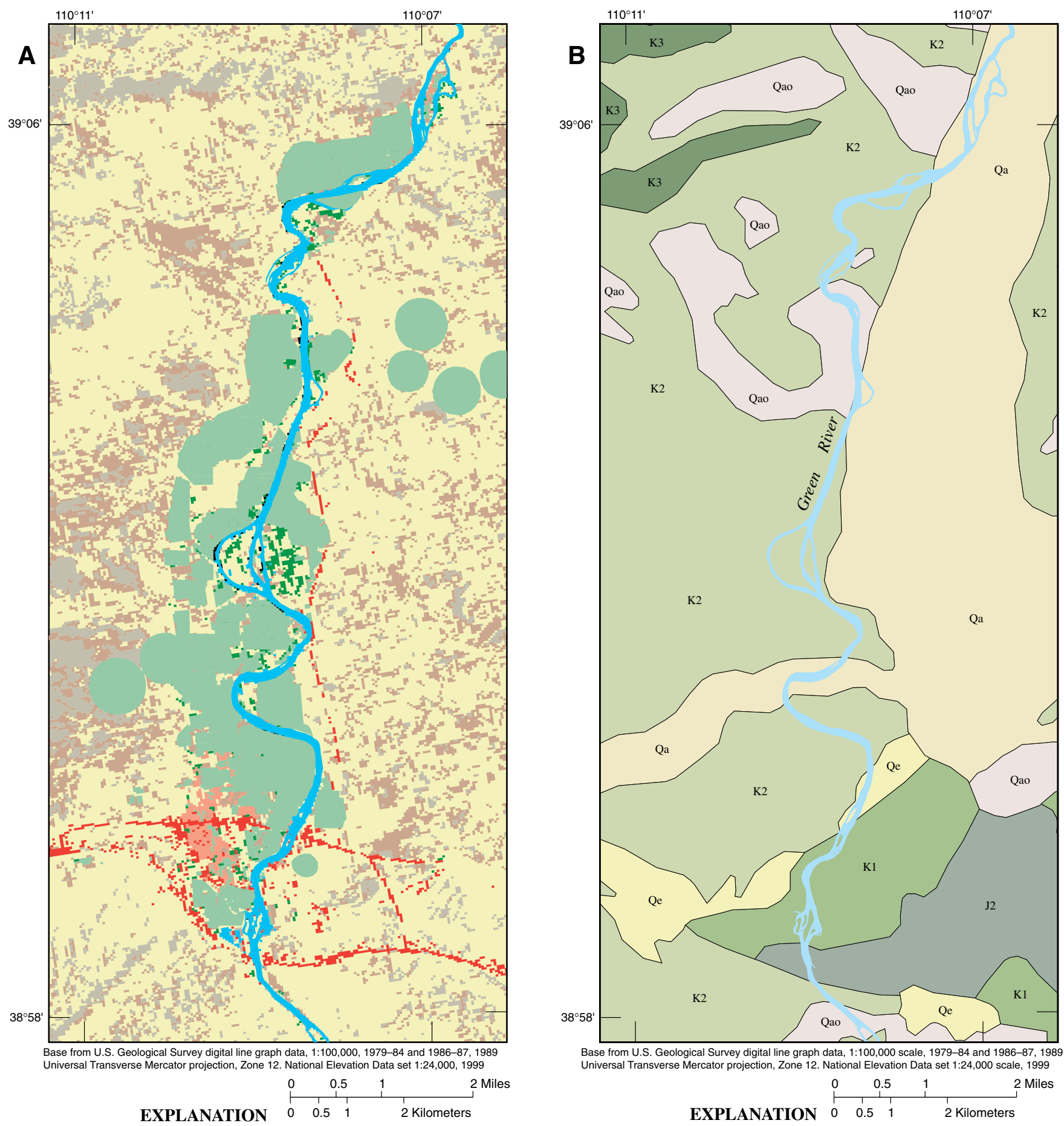

Rangeland
Forest
Agriculture
Commercial/Industrial/Transportation
Woody wetland
Water
Barren land
Residential
Shrubland

\begin{tabular}{|c|c|c|}
\hline Qa & Quaternary & Surficial deposits-alluvium and colluvium \\
\hline Qe & Quaternary & Surficial deposits-older alluvium and colluvium \\
\hline Qao & Quaternary & Surficial deposits-older alluvium and colluvium \\
\hline K1 & Cretaceous & Dakota and Cedar Mountain Formations \\
\hline K2 & Cretaceous & $\begin{array}{l}\text { Mancos Shale (Hilliard Shale and Blair Formation north } \\
\text { of Uinta Mountains), Frontier Sandstone, Mowry Shale }\end{array}$ \\
\hline K3 & Cretaceous & Uinta Mountains_-Mesaverde Group (coal) \\
\hline $\mathrm{J} 2$ & Jurassic & Uinta Mountains-Morrison Formation \\
\hline
\end{tabular}

Figure 2. (A) Land cover/use and (B) geology of the Green River study area, Utah. 


\section{Geology and Soils}

The geology of the study area consists primarily of a sequence of Cretaceous-age sedimentary rocks of marine and terrestrial origin (fig. 2). The Mancos Shale is exposed at the surface throughout large parts of the area and consists primarily of silts and clays that form low undulating hills and badland topography. The Mancos Shale was deposited in an inland sea which at one time covered much of the western interior of the country. Deposition in this restricted marine environment was conducive to the accumulation of alkali salts that result in locally moderate to high concentrations of dissolved solids in ground water. Quaternary-age alluvium is present in the study area along the floodplain of the Green River as well as along smaller tributary drainages to the river. These deposits consist primarily of sands and gravels that have been transported downstream from the Book Cliffs region.

Soils in the study area have been mostly derived from the Mancos Shale and consist primarily of Typic and Lithic Torriorthents. These soils generally are fine-silty to loamy, calcareous, and mesic (moderately moist) and generally are well drained. Soil surveys conducted in the Green River area by the U.S. Department of Agriculture Bureau of Soils in 1921 (written commun., 2005) generally indicate that the best soils for crops occur where the soils are sandy to clay loams, locally gravelly, and friable and porous, with excellent drainage. These soils are typically 1 to $6 \mathrm{ft}$ deep over the underlying shale and generally free of alkali. Along the floodplain of the river, clay loam with locally fine sandy loam more than $6 \mathrm{ft}$ deep is present. These soils also are porous and well drained, free of alkali, and therefore, can be highly productive for crops. The soil surveys determined that areas with good natural drainage (such as ravines), and hence, low water tables, promoted flushing of alkali salts from the soils during irrigation, and thus, tended to minimize build up of salts at the surface. In contrast, high water tables and clay-rich soils promoted overland runoff of salts into drainages.

\section{Hydrology and Agricultural Water Development}

The Green River is the principal perennial stream in the study area. The river emerges from the Book Cliffs and meanders generally south to its eventual junction with the Colorado River about 120 mi south of the study area. Annual peak discharge of the Green River (at Green River, Utah) generally occurs in May or June as snowmelt runs off from higher altitudes to the north of the study area and averages about $28,000 \mathrm{ft}^{3} / \mathrm{s}$, on the basis of streamflow records for 1905-2004. Minimum monthly mean discharge of the river occurs in January and is $2,300 \mathrm{ft}^{3} / \mathrm{s}$ for the same period of record (Enright and others, 2005). Discharge in the river during low-flow periods (August through February) is primarily controlled by impoundment and release at Flaming Gorge Reservoir about 290 mi upstream from the study area. Numerous ephemeral streams within the study area flow from the east and west across the Green River Valley and discharge into the Green
River (fig. 1). These streams generally flow only during and after periods of heavy precipitation that are often associated with summer thunderstorms.

Ground water in the study area occurs within the Mancos Shale but typically has high dissolved-solids concentrations. In the southern part of the area and within the limits of the town of Green River, the underlying Dakota and Cedar Mountain Formations are capable of yielding water suitable for domestic use. Shallow wells developed in the alluvium along and near the Green River floodplain also can produce adequate yields for domestic or irrigation use. All water for municipal use is provided by diversions directly from the Green River.

Early settlers used waterwheels or steam-powered pumps to lift irrigation water from the river. River bottom lands were first cultivated in 1880. The Blake City Water Ditch Company was organized at this time and canals were constructed to bring water to the dryer benchlands along the river (Geary, 1996). A diversion dam on the Green River was constructed in 1905 to divert water into two canals, then was destroyed in 1907 by floods but later rebuilt.

Presently, a system of canals roughly parallels the Green River and serves to divert water from the river to a system of ditches and laterals for agricultural use (fig. 1). Two major canals (Thayn and Green River) are located on the west side of the river and the East Side Canal serves to irrigate land on the east side of the river. Water is diverted from the river in the northern part of the study area and transported by gravity drainage to croplands along the river to the south. The principal canals are 5 to $8 \mathrm{mi}$ in length and have a combined flow of up to $130 \mathrm{ft}^{3} / \mathrm{s}$ during the irrigation season. Irrigation is mainly gravity-fed but there are scattered fields where irrigation is provided by wheel-line or central-pivot sprinkler systems.

\section{Acknowledgments}

Landowners in the agricultural areas near Green River, Utah, who provided access to sampling sites and cooperated in the process of sample collection, are gratefully acknowledged. NRCS personnel, in particular Gary Roeder, Anthony Beals, and Dave Varner are acknowledged for their insight into dissolved-solids problems and agricultural practices in the study area, as well as their assistance with data collection and well installation.

\section{Methods of Investigation}

Methods of collecting, processing, and analyzing waterquality samples and methods of determining dissolved-solids concentration and load are described in this section. 


\section{Sample Collection and Analysis}

Water samples were collected between March 2004 and May 2005 from 38 surface- and ground-water sites in the study area (fig. 1, table 1) and analyzed for physical properties and major ions (tables 2 and 3, located in back of report). All site visits included on-site field measurements of discharge, specific conductance, and water temperature. Samples from selected sites were analyzed for major ions (table 4) or dissolved-solids concentration. Surface-water samples were collected with an isokinetic sampler by using the equal-widthincrement method and depth-integration, when streams were of sufficient depth and velocity (Webb and others, 1999).

Samples from shallow or slow-moving surface water were collected from the center of flow into an open-mouth 1-liter polyethylene bottle. Ground-water samples were collected from shallow wells by using a peristaltic pump. Wells generally were purged of three casing volumes of water before a sample was collected; however, a few wells had very low capacities and samples were collected as soon as the well had recovered sufficiently following the initial purge of one casing volume. Water samples collected for analysis of dissolved constituents were filtered through a disposable 0.45 -micron capsule filter by using a peristaltic pump. Sample filtering and preservation were completed in the field.

Water samples were analyzed for major-ion concentrations at the USGS National Water Quality Laboratory (NWQL) in Lakewood, Colorado, using standard analytical techniques described in Fishman and Friedman (1989). Data are stored in the USGS National Water Information System (NWIS) database. Analytical methods and minimum reporting limits for the analyzed properties and constituents are listed in table 4.

Water samples were collected from selected sites to determine strontium and boron concentrations and the isotopic ratios of naturally occurring strontium $\left({ }^{87} \mathrm{Sr} /{ }^{86} \mathrm{Sr}\right)$ and boron $\left({ }^{11} \mathrm{~B} /{ }^{10} \mathrm{~B}\right)$. These samples were filtered through a disposable 0.45-micron capsule filter, and analyzed in the USGS stable isotope laboratory in Menlo Park, California.

\section{Dissolved-Solids Concentration and Load Estimates}

Dissolved-solids concentration was measured in water samples collected during this study; however, during some site visits water samples were not collected. Instead, a measure of specific conductance was made at the site with the intention of deriving an estimate of dissolved-solids concentration from this measurement. The method of deriving this estimate is explained in the following section of this report. The methods that were used to derive estimates of dissolved-solids loads discharging from the study area to the Green River are explained in subsequent sections of this report.

\section{Estimating Dissolved-Solids Concentration from Specific-Conductance Measurements}

Specific conductance is a measure of the capacity of water to conduct an electrical current and is a function of the types and quantities of dissolved substances in water (Radke and others, 2005). As concentrations of dissolved solids increase, specific conductance of the water also increases. Specific-conductance measurements are a good surrogate for determining dissolved-solids concentration, and a well-defined relation between specific conductance and dissolved-solids concentration exists in many waters. The ratio of dissolvedsolids concentration to the specific-conductance value was calculated for all sites (table 2). In the case where specific conductance was measured at a site but no chemical analysis was done, the specific-conductance/dissolved-solids ratio from a similar site was used.

The relation between specific conductance and dissolvedsolids concentration in study area waters varied spatially and temporally. For example, the average dissolved-solids/specificconductance ratio at site WS-3 was 0.96, while the average dissolved-solids/specific-conductance ratio at site GR-1 was 0.64 (table 2). The dissolved-solids/specific-conductance ratio at site WS-4 ranged from 0.60 to 0.99 . In the Green River area, higher dissolved-solids/specific-conductance ratios generally are associated with water containing higher concentrations of sodium and sulfate and lower ratios are associated with calcium bicarbonate/sulfate type water.

\section{Estimating Dissolved-Solids Loads}

Two methods were used to compute a dissolved-solids load discharging to the Green River from the study area. The first method is as follows: (1) determine the dissolved-solids load at points in the Green River upstream and downstream from the study area from measurements of flow and dissolvedsolids concentration or specific conductance at sites GR-1 and GR-2, (2) determine the difference between the dissolved-solids load at site GR-1 and site GR-2. This difference represents the amount of dissolved solids contributed by the study area. The accuracy of dissolved-solids load estimates derived from using this method is greatly influenced by the accuracy of discharge measurements as well as by the timing of the measurement of elements in each data pair. Diurnal fluctuations in discharge and dissolved-solids concentration are substantial at sites GR-1 and GR-2 and can result in a large amount of uncertainty when instantaneous measurements of these parameters are being compared.

The second method used to compute a dissolved-solids load discharging to the Green River from the study area is as follows: (1) determine the dissolved-solids concentration at points in the Green River upstream and downstream of the study area, (2) calculate the difference in dissolved-solids concentration between them, and (3) multiply this difference by the daily mean discharge at site GR-2 on the day of those 
measurements and a constant (0.002697). The dissolved-solids concentrations used with this method were selected preferentially on the basis of the method of determination. Those concentrations calculated from the sum of major constituents were preferred, followed by concentrations determined from analysis of residue on evaporation at $180^{\circ} \mathrm{C}\left(\mathrm{ROE} @ 180^{\circ}\right)$, and then by concentrations estimated from specific-conductance measurements. Seasonal loads were determined by averaging daily dissolved-solids load measurements in each season and multiplying that load by the number of days in a season. Seasons were defined as summer (June, July, and August), fall (September, October, and November), winter (December, January, and February), and spring (March, April, and May). An annual load was determined by summing seasonal loads. The accuracy of dissolved-solids load estimates derived by using this method is greatly influenced by the accuracy of specific-conductance measurements as well as by the timing of the measurement of elements in each data pair. The difference in specific conductance between sites GR-1 and GR-2 is generally less than 3 percent, and the minimal accuracy of calibrated instruments used to make these measurements is plus or minus 3 percent. As with the previous method, diurnal fluctuations in discharge and dissolved-solids concentration can result in a large amount of uncertainty when instantaneous measurements of these parameters are being compared. For example, measurements of specific conductance made 2 hours apart at sites GR-1 and GR-2 on December 14, 2004, were 830 and $842 \mu \mathrm{S} / \mathrm{cm}$, respectively, a difference of $12 \mu \mathrm{S} / \mathrm{cm}$. Subsequently, measurements of specific conductance were made at 15-minute intervals for a 24-hour period during December 14-
15,2004 , at these sites. The 24-hour average specific-conductance value was $830 \mu \mathrm{S} / \mathrm{cm}$ at site GR-1 and $850 \mu \mathrm{S} / \mathrm{cm}$ at site GR-2, an average difference in specific conductance between these sites of $20 \mu \mathrm{S} / \mathrm{cm}$.

\section{Discharge Measurements}

Discharge is an essential element in the calculation of dissolved-solid loads. Discharge measurements in canals and drains were made by using standard methods of the USGS (Buchanan and Somers, 1969). An Acoustic Doppler Current Profiler (ADCP) was used to determine most of the river discharge measurements used in method one (fig. 3). In most cases, using an ADCP discharge-measurement system to measure discharge is substantially faster than using conventional discharge-measurement systems and has comparable or better accuracy (Simpson, 2002). At site GR-1, the ADCP was tethered to a line-type pulley system or an inflatable kayak and towed across the river, making a complete measurement with each pass. The reported discharge is the mean discharge determined from a group of four or eight consecutive measurements. Site GR-2 corresponds to the USGS long-term gaging station, Green River at Green River, Utah. Discharge values for site GR-2 used in dissolved-solids load determination method one were either instantaneous measurements made with the ADCP or values calculated from the continuous stage recorded at the gaging station.

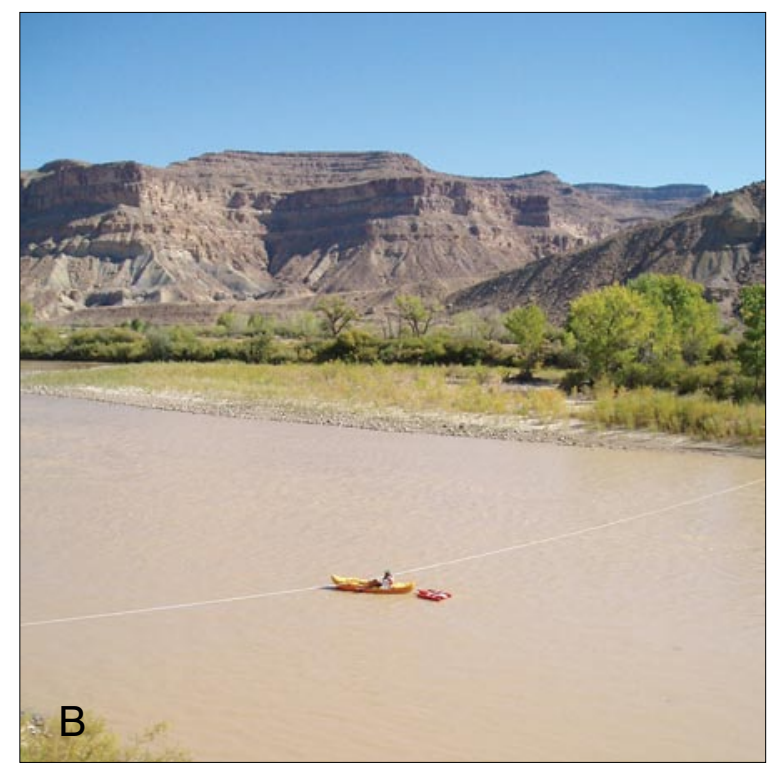

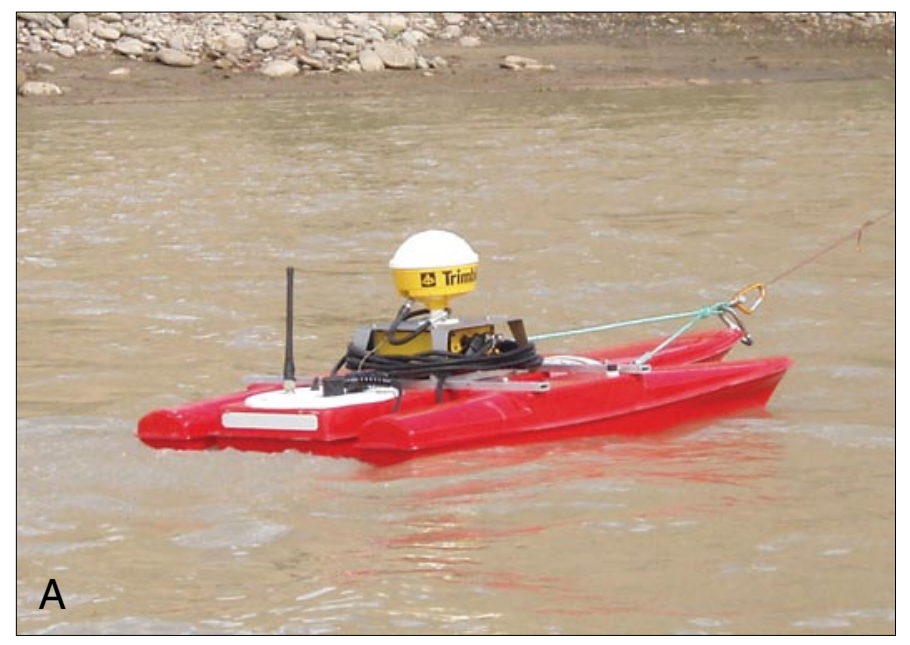

Figure 3. (A) The Acoustic Doppler Current Profiler used to make the discharge measurements at (B) site GR-1 near Green River, Utah. 
Table 1. Site characteristics and summary of dissolved-solids concentration and load for water-quality monitoring sites near Green River, Utah, March 2004 to May 2005

$[<$, less than; NA, not applicable; ddmmss, degrees, minutes, seconds $]$

\begin{tabular}{|c|c|c|c|c|c|}
\hline $\begin{array}{c}\text { Site } \\
\text { identifier }\end{array}$ & Site designation & Site type & $\begin{array}{l}\text { U.S. Geological } \\
\text { Survey site- } \\
\text { identification } \\
\text { number }\end{array}$ & $\begin{array}{l}\text { Latitude } \\
\text { (ddmmss) }\end{array}$ & $\begin{array}{l}\text { Longitude } \\
\text { (dddmmss) }\end{array}$ \\
\hline GR-1 & Green River above Green River, Utah & Stream & 390608110070601 & 390608 & 1100706 \\
\hline GR-2 & Green River at Green River, Utah & Stream & 09315000 & 385902 & 1100856 \\
\hline ESC-2 & East Side Canal at mouth near Green River, Utah & Canal & 390135110082301 & 390135 & 1100823 \\
\hline GRC-1 & Green River Canal at head near Green River, Utah & Canal & 390428110084901 & 390428 & 1100849 \\
\hline GRC-2 & Green River Canal at Wash No. 2 near Green River, Utah & Canal & 390314110084301 & 390314 & 1100843 \\
\hline GRC-3 & Green River Canal at Green River, Utah & Canal & 385917110093601 & 385917 & 1100936 \\
\hline TC-1 & Thayn Canal at Flume near Green River, Utah & Canal & 390433110085201 & 390433 & 1100852 \\
\hline WS-3 & Wash No. 3 near Green River, Utah & Drain & 390233110090001 & 390233 & 1100900 \\
\hline WS-4 & Wash No. 4 near Green River, Utah & Drain & 390146110090901 & 390146 & 1100909 \\
\hline DCH-1 & Ditch No. 1 near Green River, Utah & Drain & 390303110085301 & 390303 & 1100853 \\
\hline DCH-2 & Ditch No. 2 near Green River, Utah & Drain & 390212110092601 & 390212 & 1100926 \\
\hline DCH-3 & Ditch No. 3 near Green River, Utah & Drain & 390214110084901 & 390214 & 1100849 \\
\hline DCH-4 & Ditch No. 4 near Green River, Utah & Drain & 385854110092601 & 385854 & 1100926 \\
\hline DRN-1 & Drain No. 1 near Green River, Utah & Drain & 385948110083801 & 385948 & 1100838 \\
\hline DRN-2 & Drain No. 2 near Green River, Utah & Drain & 385917110090401 & 385917 & 1100904 \\
\hline SD-1 & Sand Drain No. 1 near Green River, Utah & Drain & 390207110092701 & 390207 & 1100927 \\
\hline SP-6 & Seep No. 6 near Green River, Utah & Seep & 385958110082301 & 385958 & 1100823 \\
\hline W-1 & Well No. 1 near Green River, Utah & Well & 385947110083301 & 385947 & 1100833 \\
\hline $\mathrm{W}-2$ & Well No. 2 near Green River, Utah & Well & 385948110083601 & 385948 & 1100836 \\
\hline $\mathrm{W}-3$ & Well No. 3 near Green River, Utah & Well & 385958110082401 & 385958 & 1100824 \\
\hline $\mathrm{W}-4$ & Well No. 4 near Green River, Utah & Well & 385958110082601 & 385958 & 1100826 \\
\hline $\mathrm{W}-5$ & Well No. 5 near Green River, Utah & Well & 390238110093001 & 390238 & 1100930 \\
\hline W-6 & Well No. 6 near Green River, Utah & Well & 390237110091101 & 390237 & 1100911 \\
\hline W-7 & Well No. 7 near Green River, Utah & Well & 390237110085501 & 390237 & 1100855 \\
\hline $\mathrm{W}-8$ & Well No. 8 near Green River, Utah & Well & 390347110083501 & 390347 & 1100835 \\
\hline W-9 & Well No. 9 near Green River, Utah & Well & 390143110091601 & 390143 & 1100916 \\
\hline $\mathrm{W}-10$ & Well No. 10 near Green River, Utah & Well & 385952110084401 & 385952 & 1100844 \\
\hline $\mathrm{W}-11$ & Well No. 11 near Green River, Utah & Well & 390222110083101 & 390222 & 1100831 \\
\hline $\mathrm{W}-12$ & Well No. 12 near Green River, Utah & Well & 390222110084101 & 390222 & 1100841 \\
\hline W-13 & Well No. 13 near Green River, Utah & Well & 390224110084801 & 390224 & 1100848 \\
\hline
\end{tabular}


Table 1. Site characteristics and summary of dissolved-solids concentration and load for water-quality monitoring sites near Green River, Utah, March 2004 to May 2005-Continued

\begin{tabular}{|c|c|c|c|c|c|c|c|}
\hline \multirow[t]{2}{*}{$\begin{array}{c}\text { Site } \\
\text { identifier }\end{array}$} & \multicolumn{3}{|c|}{$\begin{array}{l}\text { Dissolved-solids } \\
\text { concentration, } \\
\text { in milligrams per liter }\end{array}$} & \multicolumn{3}{|c|}{$\begin{array}{l}\text { Dissolved-solids } \\
\text { load, } \\
\text { in tons per day }\end{array}$} & \multirow[t]{2}{*}{$\begin{array}{l}\text { Number of } \\
\text { site visits }\end{array}$} \\
\hline & Minimum & Mean & Maximum & Minimum & Mean & Maximum & \\
\hline GR-1 & 220 & 459 & 567 & 1,660 & 3,200 & 4,740 & 13 \\
\hline GR-2 & 214 & 460 & 569 & 1,650 & 3,600 & 7,650 & 21 \\
\hline ESC-1 & 214 & 283 & 362 & 11.6 & 15.6 & 18.5 & 3 \\
\hline ESC-2 & 192 & 230 & 268 & 2.0 & 2.0 & 2.1 & 2 \\
\hline GRC-1 & 247 & 440 & 566 & 1.5 & 33.5 & 74.2 & 5 \\
\hline GRC-2 & 252 & 376 & 519 & 38.7 & 38.7 & 38.7 & 3 \\
\hline GRC-3 & 271 & 409 & 547 & 8.8 & 14.0 & 19.2 & 2 \\
\hline TC-1 & 356 & 356 & 356 & 25.0 & 25.0 & 25.0 & 1 \\
\hline WS-1 & 386 & 441 & 496 & $<.1$ & $<.1$ & $<.1$ & 2 \\
\hline WS-2 & 420 & 2,540 & 3,990 & .2 & 1.4 & 4.5 & 4 \\
\hline WS-3 & 401 & 3,410 & 4,250 & .1 & .2 & .6 & 6 \\
\hline WS-4 & 284 & 1,130 & 3,990 & .2 & 3.4 & 6.9 & 5 \\
\hline DCH-1 & 303 & 303 & 303 & $<.1$ & $<.1$ & $<.1$ & 1 \\
\hline DCH-2 & 296 & 296 & 296 & $<.1$ & $<.1$ & $<.1$ & 1 \\
\hline DCH-3 & 533 & 533 & 533 & .4 & .4 & .4 & 1 \\
\hline DCH-4 & 538 & 538 & 538 & 1.1 & 1.1 & 1.1 & 1 \\
\hline DRN-1 & 290 & 422 & 589 & .1 & 1.2 & 3.5 & 3 \\
\hline DRN-2 & 337 & 2,660 & 5,910 & .6 & 1.7 & 3.7 & 5 \\
\hline SD-1 & 527 & 527 & 527 & 4.6 & 4.6 & 4.6 & 1 \\
\hline SP-1 & 3,880 & 3,880 & 3,880 & $<.1$ & $<.1$ & $<.1$ & 1 \\
\hline SP-2 & 5,080 & 5,080 & 5,080 & $<.1$ & $<.1$ & $<.1$ & 1 \\
\hline SP-3 & 4,280 & 4,460 & 4,640 & $<.1$ & $<.1$ & $<.1$ & 4 \\
\hline SP-4 & 2,770 & 3,200 & 3,640 & $<1.0$ & 4.2 & 7.5 & 2 \\
\hline SP-5 & 4,040 & 4,040 & 4,040 & $<.1$ & $<.1$ & $<.1$ & 1 \\
\hline SP-6 & 1,680 & 1,680 & 1,680 & .5 & $<.5$ & $<.5$ & 1 \\
\hline W-1 & 1,010 & 1,110 & 1,270 & NA & NA & NA & 3 \\
\hline W-2 & 687 & 709 & 737 & NA & NA & NA & 4 \\
\hline W-3 & 876 & 999 & 1,080 & NA & NA & NA & 4 \\
\hline W-4 & 731 & 815 & 914 & NA & NA & NA & 3 \\
\hline W-5 & 40,800 & 48,200 & 55,900 & NA & NA & NA & 4 \\
\hline W-6 & 5,090 & 6,380 & 8,460 & NA & NA & NA & 5 \\
\hline W-7 & 1,350 & 1,570 & 1,830 & NA & NA & NA & 4 \\
\hline W-8 & 2,160 & 3,500 & 4,290 & NA & NA & NA & 3 \\
\hline W-9 & 1,450 & 1,700 & 1,860 & NA & NA & NA & 3 \\
\hline W-10 & 2,070 & 2,190 & 2,310 & NA & NA & NA & 2 \\
\hline W-11 & 1,830 & 4,620 & 6,510 & NA & NA & NA & 3 \\
\hline W-12 & 8,530 & 10,800 & 12,400 & NA & NA & NA & 3 \\
\hline W-13 & 819 & 940 & 1,060 & NA & NA & NA & 2 \\
\hline
\end{tabular}


Table 4. Field and analytical methods and minimum reporting levels for water-quality field measurements and constituent concentrations in samples collected from water-quality monitoring sites near Green River, Utah

[Unit: $\mathrm{ft} 3 / \mathrm{s}$, cubic feet per second; $\mu \mathrm{S} / \mathrm{cm}$, microsiemens per centimeter at $25^{\circ} \mathrm{C} ; \mathrm{mg} / \mathrm{L}$, milligrams per liter; ${ }^{\circ} \mathrm{C}$, degrees Celsius; Analytical method: ICP, inductively coupled plasma; IC, ion chromatography; NA, not applicable]

\begin{tabular}{|c|c|c|c|c|}
\hline Measurement or constituent & Unit & Field method & Analytical method & $\begin{array}{l}\text { Minimum } \\
\text { reporting } \\
\text { level }\end{array}$ \\
\hline \multicolumn{5}{|c|}{ Physical Properties } \\
\hline Discharge, instantaneous & $\mathrm{ft}^{3} / \mathrm{s}$ & Mid-interval & NA & Variable \\
\hline Specific conductance & $\mu \mathrm{S} / \mathrm{cm}$ at $25^{\circ} \mathrm{C}$ & Point & NA & 1 \\
\hline Water temperature & ${ }^{\circ} \mathrm{C}$ & Point & NA & .1 \\
\hline Alkalinity & $\mathrm{mg} / \mathrm{L}$ & Titration & NA & 1 \\
\hline \multicolumn{5}{|c|}{ Major lons } \\
\hline Calcium, dissolved, as $\mathrm{Ca}$ & $\mathrm{mg} / \mathrm{L}$ & NA & ICP & .1 \\
\hline Chloride, dissolved, as $\mathrm{Cl}$ & $\mathrm{mg} / \mathrm{L}$ & NA & IC & .1 \\
\hline Fluoride, dissolved, as F & $\mathrm{mg} / \mathrm{L}$ & NA & Ion-selective electrode & .1 \\
\hline Hardness, total, as $\mathrm{CaCO}_{3}$ & $\mathrm{mg} / \mathrm{L}$ & NA & Calculated & 1 \\
\hline Magnesium, dissolved, as Mg & $\mathrm{mg} / \mathrm{L}$ & NA & $\mathrm{ICP}$ & .1 \\
\hline Potassium, dissolved, as $\mathrm{K}$ & $\mathrm{mg} / \mathrm{L}$ & NA & ICP & .1 \\
\hline Silica, dissolved, as $\mathrm{Si}$ & $\mathrm{mg} / \mathrm{L}$ & NA & ICP & .1 \\
\hline Sodium, dissolved, as $\mathrm{Na}$ & $\mathrm{mg} / \mathrm{L}$ & NA & ICP & .1 \\
\hline Sulfate, dissolved, as $\mathrm{SO}_{4}$ & $\mathrm{mg} / \mathrm{L}$ & NA & IC & .1 \\
\hline Solids, dissolved, sum of constituents & $\mathrm{mg} / \mathrm{L}$ & NA & Calculated & 1 \\
\hline Solids, dissolved, residue on evaporation (ROE) at $180^{\circ} \mathrm{C}$ & $\mathrm{mg} / \mathrm{L}$ & NA & Gravimetric & 10 \\
\hline
\end{tabular}

\section{Ground-Water Levels in Shallow Monitoring Wells}

Within the study area the depth to the ground-water table and the quality of that water are related to consumption of ground water by vegetation, deep percolation of applied irrigation water, and the period of active discharge of ground water to drains and the river. Natural drainage of ground water to the Green River and ephemeral stream channels occurs in some of the study area where the altitude of the water table is generally higher than that of the bed of the river and streams.

Measurements of depth to water were made during the study in 13 water-quality monitoring wells that were finished in the shallow part of the ground-water system. Of these wells, eight were drilled in 2004 for this study and five were previously constructed during the 1990s for a town water-availability study. All were completed in the shallow part of the ground-water system. Depth to water in these wells ranged from 1.33 to $15.50 \mathrm{ft}$ below land surface and averaged $7.56 \mathrm{ft}$ below land surface (table 2, fig. 4). Much of the natural vegetation growing in the study area is classed as a phreatophyte and some of these plants, such as greasewood, can exist in areas where the depth to water is greater than $30 \mathrm{ft}$ (Robinson,
1958). Consequently, ground water within the study area is generally available for consumption by phreatophytes, thereby providing a process by which dissolved solids in ground water are concentrated.

Water levels in individual monitoring wells varied during the study (table 2). The largest range in depth to water, 3.93 to $10.25 \mathrm{ft}$ below land surface, was measured in well W-11 and the smallest range, 9.16 to $10.90 \mathrm{ft}$ below land surface, was measured in well W-2. Factors contributing to the variation in water levels in the monitoring wells may include one or more of the following: (1) rate and timing of irrigation, (2) seepage from canals, (3) distance from the Green River and the stage of the river, (4) discharge of shallow ground water to drains and seeps, (5) evapotranspiration of shallow ground water, and (6) consumptive use of shallow ground water by vegetation. Water levels rose in five wells and declined in five wells from July 2004 to September 2004. These changes in water levels may be the result of variable irrigation practices in the areas adjacent to the individual wells. Water levels declined in 9 of 10 wells from September 2004 to February 2005. This may be the result of minimal ground-water recharge associated with irrigation and continued discharge of ground water to the river and drains during fall and winter. 


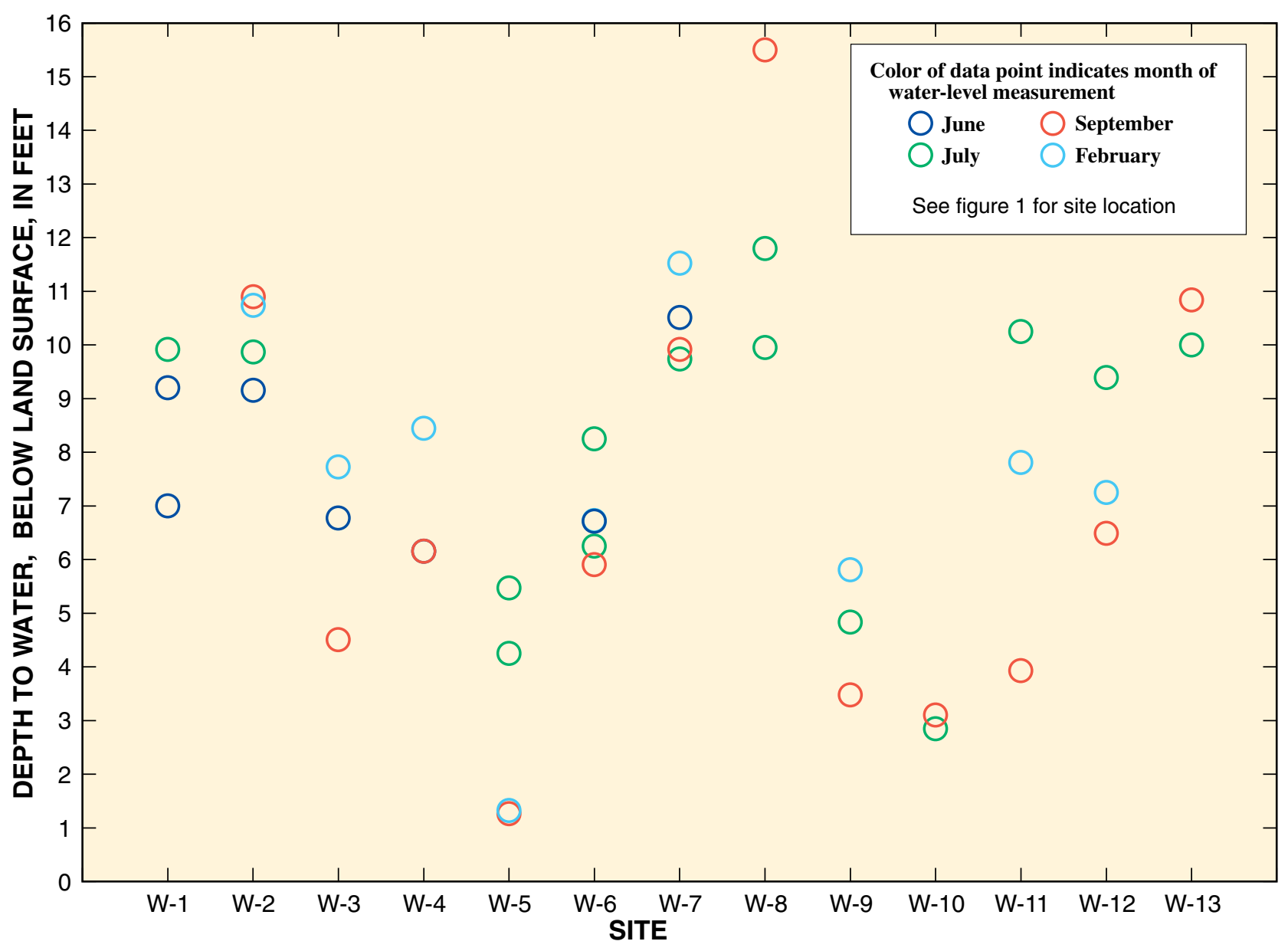

Figure 4. Water levels in monitoring wells near Green River, Utah.

\section{Chemical Quality of Water}

Land and water-resource management decisions related to controlling the transport of salt from Green River agricultural lands to the Green River depend on a basic knowledge of dissolved-solids concentration and load in the water. Water samples were collected from water-quality monitoring sites on the Green River and major canals, and at drains, seeps, and wells in the study area, and the analytical results were used to describe the chemical quality of water from those sites.

\section{Major-Ion Composition of Water}

The relative major-ion composition of water in the study area varies substantially; however, sulfate was the predominant anion in most of the water sampled. Calcium was the predominant cation in water sampled from drains and magnesium was the predominant cation in a sample from a seep (SP-2) adjacent to the river and above the agricultural areas. Sulfate made up 44 percent of the dissolved solids in water from this seep, the largest proportion of sulfate in any water sampled in the study area (table 5). The relative major-ion composition of water in the Green River and in major canals near Green River, Utah, is a mixed type with calcium and sodium the predominant cations, and bicarbonate and sulfate the predominant anions. The dissolved-solids composition of water in the Green River was similar above and below the agricultural areas near Green River, Utah, despite the fact that water from seeps and drains that discharge to the Green River in the intervening reach had relatively high concentrations of sulfate. A plot of the relative composition of water from drains falls between that of the Green River and seep SP-2, indicating that water in drains is probably composed of both ground-water discharge similar to that present in seep SP-2 and surface water similar to that present in the Green River (fig. 5). The dissolved-solids composition of water from wells was variable; however, sulfate generally was the predominant anion. The concentration of cations in the wells generally was balanced among calcium, magnesium, and sodium. 
Table 5. Relative percentage of major ions in water samples collected at selected sites near Green River, Utah

\begin{tabular}{|c|c|c|c|c|c|c|c|c|c|c|c|}
\hline \multirow{2}{*}{$\begin{array}{c}\text { Site } \\
\text { identi- } \\
\text { fier } \\
\text { (see } \\
\text { table 1) }\end{array}$} & \multirow{2}{*}{$\begin{array}{l}\text { Site } \\
\text { type }\end{array}$} & \multirow{2}{*}{$\begin{array}{l}\text { Date of } \\
\text { sample } \\
\text { collection }\end{array}$} & \multirow{2}{*}{$\begin{array}{l}\text { Dissolved- } \\
\text { solids } \\
\text { concentration, } \\
\text { in milli- } \\
\text { equivalents } \\
\text { per liter } \\
\end{array}$} & \multicolumn{8}{|c|}{$\begin{array}{l}\text { Ion concentration as percentage of total } \\
\text { dissolved-solids concentration }\end{array}$} \\
\hline & & & & $\begin{array}{l}\text { Cal- } \\
\text { cium }\end{array}$ & $\begin{array}{l}\text { Magne- } \\
\text { sium }\end{array}$ & Sodium & $\begin{array}{l}\text { Potas- } \\
\text { sium }\end{array}$ & Chloride & Fluoride & $\begin{array}{l}\text { Bicar- } \\
\text { bonate }\end{array}$ & Sulfate \\
\hline GR-1 & stream & 08/17/04 & 16 & 18 & 13 & 19 & 1 & 5 & $<1$ & 20 & 25 \\
\hline GR-1 & stream & $11 / 16 / 04$ & 17.7 & 17 & 13 & 20 & $<1$ & 4 & $<1$ & 19 & 26 \\
\hline GR-1 & stream & $09 / 23 / 04$ & 17.5 & 18 & 13 & 19 & $<1$ & 5 & $<1$ & 19 & 26 \\
\hline GR-1 & stream & $12 / 15 / 04$ & 17 & 20 & 14 & 17 & $<1$ & 4 & $<1$ & 20 & 24 \\
\hline GR-2 & stream & $11 / 16 / 04$ & 17.8 & 18 & 13 & 20 & $<1$ & 4 & $<1$ & 19 & 26 \\
\hline WS-2 & drain & 06/07/04 & 54.4 & 21 & 16 & 12 & $<1$ & 2 & $<1$ & 8 & 40 \\
\hline WS-3 & drain & 06/08/04 & 115 & 24 & 13 & 14 & $<1$ & 3 & $<1$ & 6 & 40 \\
\hline WS-4 & drain & 02/10/05 & 115 & 23 & 15 & 14 & $<1$ & 2 & $<1$ & 8 & 39 \\
\hline SP-2 & seep & 08/17/04 & 140 & 19 & 23 & 10 & $<1$ & 1 & $<1$ & 4 & 44 \\
\hline W-1 & well & 06/09/04 & 37.6 & 21 & 15 & 17 & $<1$ & 3 & $<1$ & 22 & 21 \\
\hline W-6 & well & 07/13/04 & 212 & 8 & 19 & 23 & $<1$ & 4 & $<1$ & 4 & 42 \\
\hline $\mathrm{W}-7$ & well & 07/13/04 & 42.5 & 15 & 18 & 16 & 1 & 3 & $<1$ & 13 & 33 \\
\hline
\end{tabular}

\section{Dissolved Solids in Surface Water}

The concentration of dissolved solids (measured or estimated from specific-conductance measurements) in the Green River, major canals, and drains ranged from 192 to 5,910 mg/L (fig. 6, table 1). The Green River supplies nearly all of the water used for irrigation in the study area and as a result, the concentration of dissolved solids in the Green River directly affects the amount of salt being delivered to the agricultural areas through the irrigation distribution system. During this study, the concentration of dissolved solids in samples from the Green River (sites GR-1 and GR-2) ranged from 214 to $569 \mathrm{mg} / \mathrm{L}$. Concentrations of dissolved solids in canals and tail-water ditches were similar to those in the Green River and generally were less than $1,000 \mathrm{mg} / \mathrm{L}$.

The concentration of dissolved solids did not vary substantially from the head to the tail of canals in the study area. For example, the dissolved-solids concentration at the head of the Green River Canal (site GRC-1) on September 21, 2004, was $519 \mathrm{mg} / \mathrm{L}$, and it was $547 \mathrm{mg} / \mathrm{L}$ at the tail (site GRC-3) (table 2), an increase of about 5 percent along the 8-mi reach between sites. Downstream increases in the concentration of dissolved solids in study-area canals may be a result of evaporation or evapotranspiration of water directly from the canal or the addition of dissolved solids in return flow from tail-water ditches discharging or seeping back into the canals.

\section{Dissolved Solids in Ground Water}

Water from seeps and shallow wells within the study area had the highest concentration of dissolved solids, generally in excess of 1,000 mg/L. The elevated concentration of dissolved solids in shallow ground water probably results from the addition of salts in irrigation water, concentration by evaporation and evapotranspiration, and chemical weathering of rocks 
EXPLANATION

$\square$ Green River Canal (Site GRC-1)

$\square$ Drains (Various)

$\square$ Seep (SP-2)

$\square$ Green River above Green River, Utah (Site GR-1)

$\square$ Wells (Various)

$\square$ Green River at Green River, Utah (Site GR-2)

See figure 1 for site location

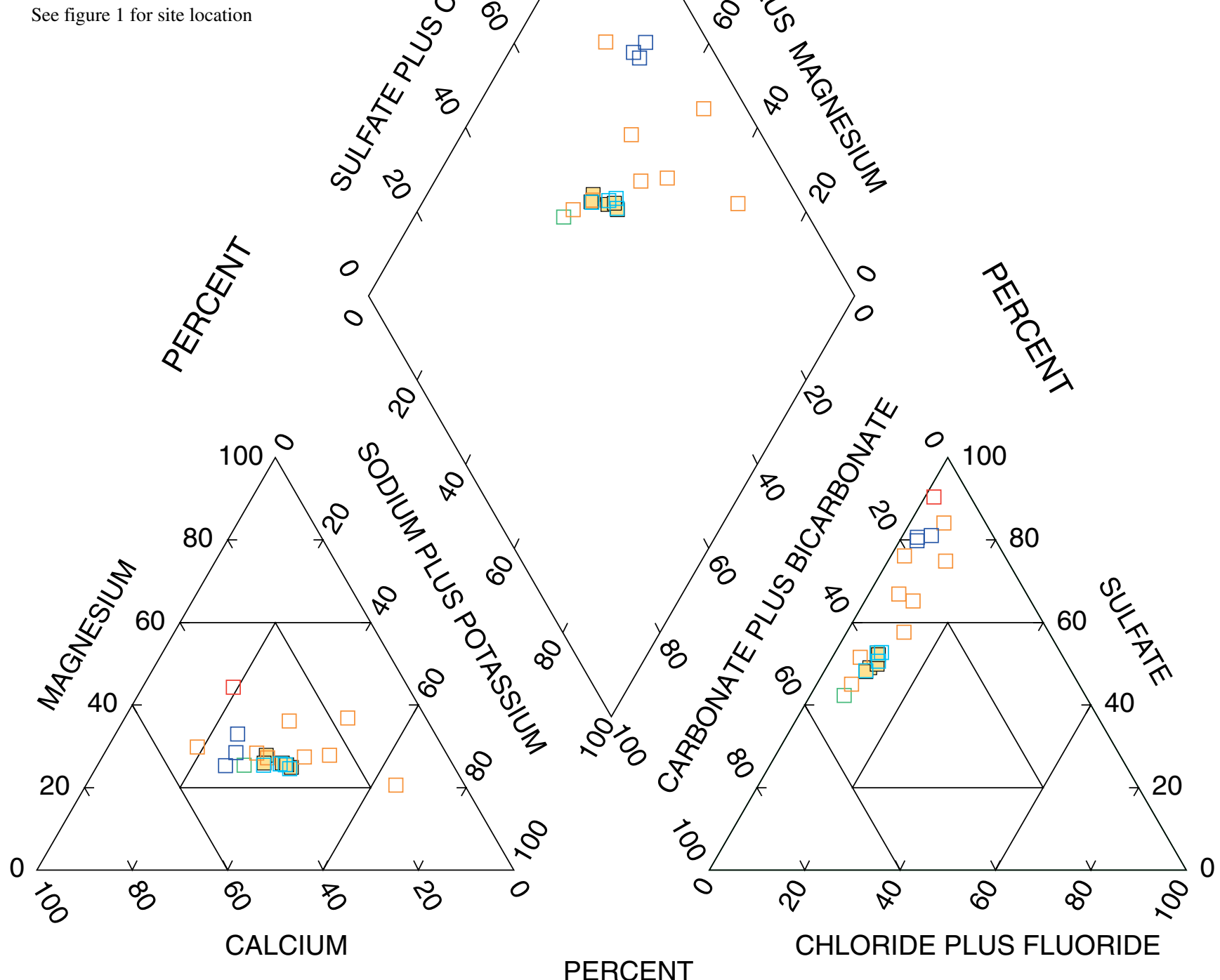

Figure 5. Relative composition of water samples collected from the Green River study area, Utah. 

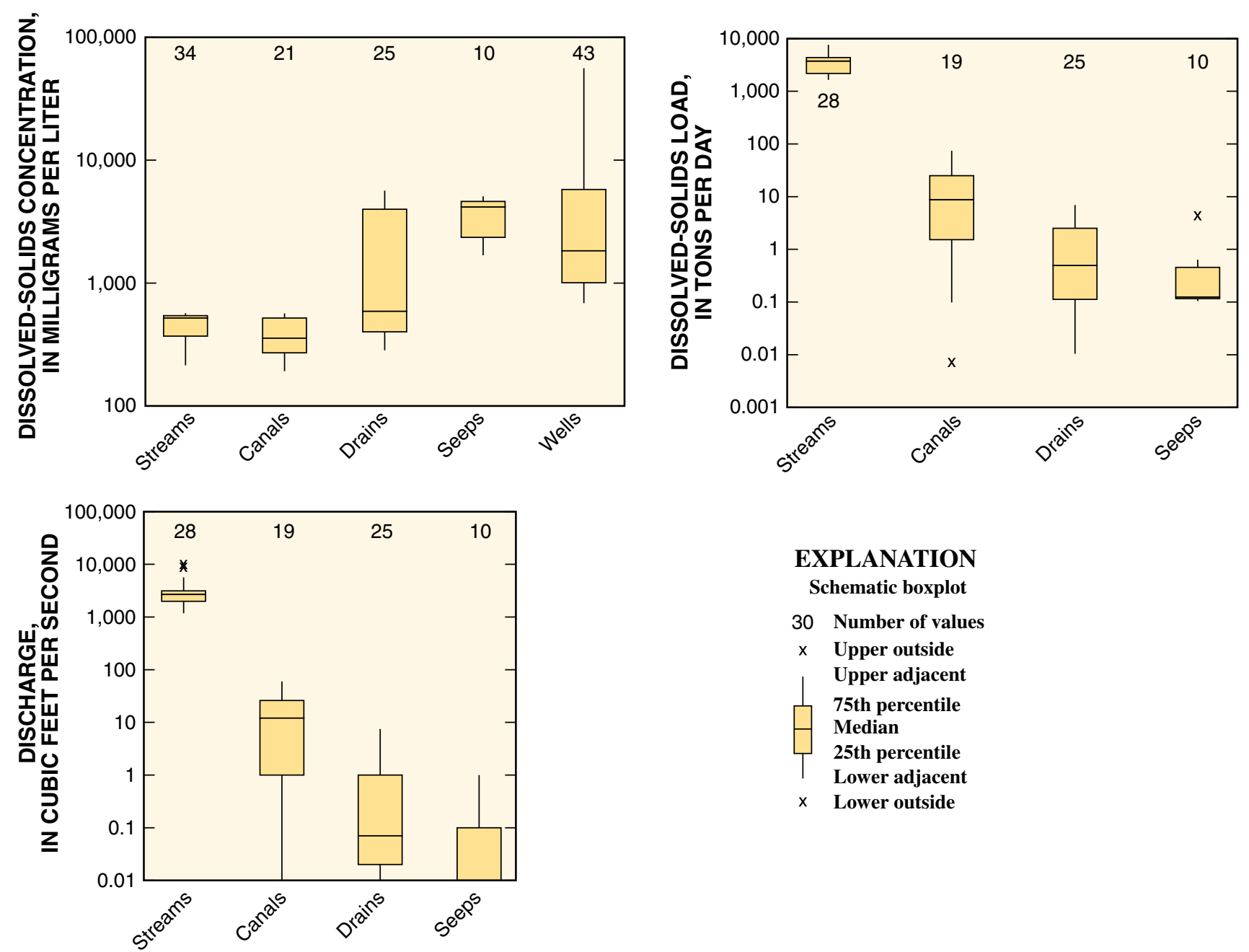

Figure 6. Distribution of dissolved-solids concentration and load, and discharge, in waters of the Green River study area, Utah.

and soil. These processes can occur along short ground-water flow paths. For example, water samples from seep SP-4 (fig. 7), which is adjacent to fields at the northern end of the study area, had an average dissolved-solids concentration of 3,200 $\mathrm{mg} / \mathrm{L}$ (table 1) even though the dissolved-solids concentration in water delivered to those fields was less than $600 \mathrm{mg} / \mathrm{L}$.

The dissolved-solids concentration in the shallow part of the ground-water system ranged from 687 to $55,900 \mathrm{mg} / \mathrm{L}$ (fig. 6 , table 1). The lowest dissolved-solids concentrations were generally measured in samples collected from wells located near the river. For example, water from wells W-1, W-2,

$\mathrm{W}-3, \mathrm{~W}-4$, and $\mathrm{W}-13$ had a mean dissolved-solids concentration of $905 \mathrm{mg} / \mathrm{L}$. These shallow wells were completed in coarser-grained alluvial material and may receive substantial recharge from tail-water ditches or from the river. The highest dissolved-solid concentrations were measured in water from wells W-5 (55,900 mg/L), and W-12 (12,400 mg/L). Both of these wells are located in low-lying areas relative to the sur- rounding topography that may be small, closed ground-water basins. As a result, water that seeps into these basins from agricultural activities or is deposited through natural precipitation dissolves minerals from the basin soil and rock, which are further concentrated through evaporation. The very high dissolved-solids concentrations measured in these two shallow wells are not evident in any of the seeps that were sampled; the dissolved-solids concentration in samples from seeps ranged from 1,680 to $5,080 \mathrm{mg} / \mathrm{L}$ (table 1 ). This indicates that although concentrations of dissolved solids in the shallow part of the ground-water system in the vicinity of these wells are high relative to other locations in the shallow part of the ground-water system, these high dissolved-solids-concentration zones may not have a substantial effect on the dissolvedsolids load discharged to the Green River. 


\section{Salt-Loading Factor}

One measure of the potential for movement of salts from irrigation distribution systems to the Green River is the difference between the concentration of dissolved solids in water distributed for irrigation and the concentration of dissolved solids in ground water discharging into the Green River. The difference is the amount of salt accumulated in ground water that could possibly be attributed to deep percolation of unconsumed irrigation water. This measure was termed a "salt-loading factor" by Hedlund (1994) and is reported in units of tons of dissolved solids per acre-ft of deep percolation. Deep percolation is defined as water that has been applied to irrigated fields but has seeped below the root zone and is unconsumed by crops, or water that has seeped from irrigation delivery systems and is likewise not consumed or evaporated. The saltloading factor assumes that all the ground water discharging from seeps and drains entered the aquifer from deep percolation of unconsumed irrigation water.

The flow-weighted concentration of dissolved solids in water distributed to the Green River Valley by the Thayn Canal, East Side Canal, and Green River Canal was $357 \mathrm{mg} / \mathrm{L}$. This concentration is based on measurements of discharge and specific conductance or dissolved solids at the head of the canals during the irrigation season (table 6). The concentration of dissolved solids in water samples collected from seeps and drains during base flow (from February through April 2005 only) was representative of ground-water discharge that is assumed to result from deep percolation of unconsumed irrigation water. The mean concentration in water collected from seeps and drains was $4,170 \mathrm{mg} / \mathrm{L}$. Assuming no mixing with any other sources, the increase in dissolved-solids concentration that occurs along flow paths followed by deep percolation, such as through evapotranspiration and/or mineral dissolution, was $3,810 \mathrm{mg} / \mathrm{L}$ or 5.2 tons of dissolved solids per acre-ft of deep percolation.

\section{Dissolved-Solids Load Discharged to the Green River}

In the Green River study area, dissolved solids are discharged to the Green River from seeps, in drains, and irrigation tail-water ditches, and as return flow from canals. No perennial streams discharge to the Green River in this reach; however, ephemeral streams may discharge substantial dissolved-solids loads during storms. Because only a small part of the basins drained by these ephemeral streams include Green River agricultural areas, no samples were collected or measurements made during storm events. The dissolved-solids load from 17 drains or seeps visited during the study ranged from less than 0.1 to 7.5 tons/d with a median of 0.35 ton/d. The unusually low flows in the Green River during August and September 2004 made observations of seeps in the river banks possible (fig. 7). The seeps that were observed during reconnaissance of river banks generally had the same range of flow
Table 6. Discharge and dissolved-solids concentration at selected water-quality monitoring sites used in the calculation of a salt-loading factor for the Green River study area, Utah

[e, estimated; <, less than]

\begin{tabular}{|c|c|c|c|c|c|}
\hline $\begin{array}{c}\text { Site } \\
\text { identi- } \\
\text { fier } \\
\text { (see } \\
\text { table 1) }\end{array}$ & $\begin{array}{l}\text { Site } \\
\text { type }\end{array}$ & Date & $\begin{array}{l}\text { Dis- } \\
\text { charge, } \\
\text { in cubic } \\
\text { feet per } \\
\text { second }\end{array}$ & $\begin{array}{l}\text { Dissolved- } \\
\text { solids } \\
\text { concent- } \\
\text { ration, } \\
\text { in mil- } \\
\text { ligrams } \\
\text { per liter }\end{array}$ & $\begin{array}{c}\text { Dis- } \\
\text { solved- } \\
\text { solids } \\
\text { load, } \\
\text { in tons } \\
\text { per day }\end{array}$ \\
\hline \multicolumn{6}{|c|}{ Green River Valley canal inflow } \\
\hline GRC-1 & canal & 06/07/04 & 60 & 247 & 40 \\
\hline GRC-1 & canal & 07/13/04 & $\mathrm{e} 52$ & 350 & 49 \\
\hline GRC-1 & canal & $09 / 21 / 04$ & e54 & 519 & 76 \\
\hline TC-1 & canal & 06/07/04 & 24.5 & 247 & 16 \\
\hline TC-1 & canal & $07 / 13 / 04$ & 26 & 356 & 25 \\
\hline TC-1 & canal & $09 / 21 / 04$ & 7.6 & 519 & 11 \\
\hline ESC-1 & canal & 06/09/04 & 25 & 274 & 18 \\
\hline ESC-1 & canal & $07 / 14 / 04$ & 17 & 362 & 17 \\
\hline ESC-1 & canal & 09/21/04 & e10 & 519 & 14 \\
\hline \multicolumn{6}{|c|}{ Green River Valley ground-water discharge } \\
\hline DRN-2 & drain & $02 / 10 / 05$ & .04 & 5,670 & 6 \\
\hline $\mathrm{DRN}-2$ & drain & $04 / 01 / 05$ & .05 & 5,910 & .8 \\
\hline WS-2 & drain & $02 / 10 / 05$ & .02 & 3,830 & .2 \\
\hline WS-3 & drain & $02 / 10 / 05$ & .01 & 4,070 & .1 \\
\hline WS-3 & drain & $03 / 31 / 05$ & .01 & 4,250 & .1 \\
\hline WS-4 & drain & 02/10/05 & .02 & 3,990 & .2 \\
\hline SP-1 & seep & 06/07/04 & $<.01$ & 3,880 & $<.2$ \\
\hline SP-2 & seep & 08/17/04 & $<.01$ & 5,080 & $<.2$ \\
\hline SP-3 & seep & 06/08/04 & $<.01$ & 4,640 & $<.2$ \\
\hline SP-3 & seep & 07/07/04 & $<.01$ & 4,610 & $<.2$ \\
\hline SP-3 & seep & $07 / 13 / 04$ & $<.01$ & 4,320 & $<.2$ \\
\hline SP-3 & seep & $09 / 21 / 04$ & $<.01$ & 4,280 & $<.2$ \\
\hline SP-4 & seep & 08/17/04 & e1 & 2,770 & e7.5 \\
\hline SP-4 & seep & $09 / 23 / 04$ & $<.1$ & 3,640 & $<1$ \\
\hline SP-5 & seep & $09 / 21 / 04$ & $<.01$ & 4,040 & $<.2$ \\
\hline SP-6 & seep & $09 / 22 / 04$ & $<.1$ & 1,680 & $<.5$ \\
\hline
\end{tabular}




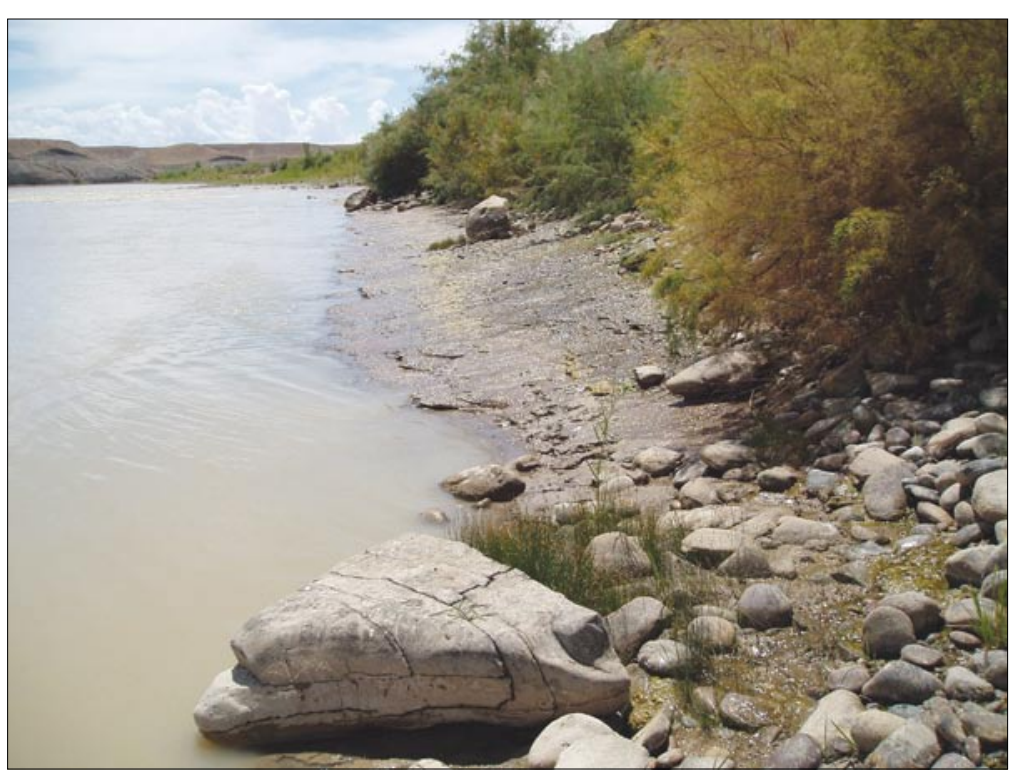

Figure 7. Seeps at site SP-4 along the western bank of the Green River (looking downstream) adjacent to agricultural fields near Green River, Utah, August 2004.

(See figure 1 for site location.)

and specific-conductance values as those that were sampled and analyzed for dissolved-solids concentration. Many of the seeps had intermittent flow with periods of no flow from late fall through early spring.

Measurements of flow and dissolved-solids concentration or specific conductance were used to determine the dissolved-solids load in the Green River immediately above and below the agricultural areas near Green River. Seven paired measurements were made at sites GR-1 and GR-2 (table 7, at back of report). For these paired measurements the calculated dissolved-solids load in the Green River ranged from 1,650 to 4,740 tons/d at site GR-1, and from 1,670 to 4,780 tons/d at site GR-2. Dissolved-solids loads in the Green River above the agricultural areas (at site GR-1) were compared with dissolved-solids loads in the Green River below the agricultural areas (at site GR-2) to determine if there was a measurable addition of dissolved solids to the river in this reach. Considerable variability in discharge occurs throughout most days at site GR-2. This variability can have a strong influence on differences in instantaneous dissolved-solid loads measured at these two sites. Because of the variability in Green River discharge, instantaneous dissolved-solids loads at site GR-1 were compared to (1) the load at site GR-2 calculated from a subsequent instantaneous discharge measurement; (2) the load at site GR-2 calculated from daily mean discharge; and (3) the load at site GR-2 calculated from the recorded discharge for the time corresponding to the measurement at site GR-1 (table 7). No significant gains in dissolved-solids load were observed between sites GR-1 and GR-2; however, the error associated with the calculations of dissolved solids at site GR-1 is greater than 80 tons/d, so gains less than this amount are possible.
The previous method of determining the dissolved-solids load discharging from the study area produced inconclusive results because of the uncertainty associated with measuring the small changes in discharge between sites GR-1 and GR-2 relative to the total discharge in the river. Consequently, a second method, as previously described in the "Methods of Investigation" section of this report, was used to determine the difference in dissolved-solids load between these sites. Nine paired measurements of dissolved-solids concentration at sites GR-1 and GR-2 were selected from June 1, 2004, to May 31, 2005, and a difference in dissolved-solids concentration and load between sites was calculated for each pair of measurements. The estimated dissolved-solids load between sites GR-1 and GR-2 determined from these measurements ranged from 7 to 69 tons/d (table 8, at back of report). Estimates of the dissolved-solids load discharging from the study area seasonally range from 2,600 tons in the winter to 6,400 tons in the spring (table 9). An estimated 15,700 tons of dissolved solids were discharged from the study area from June 1, 2004, to May 31, 2005. Seasonal and annual estimates of the dissolved solids discharging to the Green River from the study area reflect the unique combination of climatic and anthropogenic influences associated with the stated time period. Additionally, these dissolved-solids load estimates do not differentiate the load component associated with processes within the study area and a possible load component associated with a regional ground-water flow system.

Table 9. Estimated dissolved-solids load discharged to the Green River from the study area, June 1, 2004, to May 31, 2005

\begin{tabular}{llcc}
\hline Season & $\begin{array}{c}\text { Average } \\
\text { daily load, } \\
\text { in tons }\end{array}$ & $\begin{array}{c}\text { Total } \\
\text { load, } \\
\text { in tons }\end{array}$ & $\begin{array}{c}\text { Portion of } \\
\text { annual load, } \\
\text { in percent }\end{array}$ \\
\hline Summer & 42 & 3,900 & 25 \\
Fall & 31 & 2,800 & 18 \\
Winter & 29 & 2,600 & 16 \\
Spring & 69 & 6,400 & 41 \\
Annual & 43 & 15,700 & 100 \\
\hline
\end{tabular}

\section{Differentiation of Dissolved-Solids Sources}

Naturally occurring isotopes of strontium in ground water are useful tools for differentiating dissolved-solids sources. The delta strontium- $87\left(\delta^{87} \mathrm{Sr}\right)$ value is a measure of the isotopic ratio of naturally occurring ${ }^{87} \mathrm{Sr}$ and ${ }^{86} \mathrm{Sr}$. Unlike other isotopes, $\mathrm{Sr}$ isotopes do not measurably fractionate in nature. Instead, $\delta^{87} \mathrm{Sr}$ values provide insight into water-rock interaction processes. In similar lithologies, a water sample representing a shorter hydrologic flow path (irrigation return flow) will likely have a different $\mathrm{Sr}$ isotopic signal than a water sample representing a longer hydrologic flow path (regional 
aquifer dissolved-solids source; Barbieri and Morotti, 2003). For example, Nimz and others (1992) determined that shallow ground water contained positive $\delta^{87} \mathrm{Sr}$ values as a result of water-rock interaction and that deeper regional ground water contained negative $\delta^{87} \mathrm{Sr}$ values as a result of increased residence time for interaction with the more chemically resistant mineral phases. Strontium isotopes also have been used successfully to differentiate dissolved-solids sources in water from southeastern Utah (Spangler and others, 1996; Naftz and others, 1997).

Boron isotopes also can be used for differentiating dissolved-solids sources. The delta boron- $11\left(\delta^{11} \mathrm{~B}\right)$ value is a measure of the isotopic ratio of naturally occurring ${ }^{11} \mathrm{~B}$ and ${ }^{10} \mathrm{~B}$. Natural water has a wide range of $\delta^{11} \mathrm{~B}$ values, ranging from -16 to +59 permil (Vengosh and others, 1994). Examples of values for several end member waters include: -0.9 to +10.2 permil for non-marine sodium borate minerals, +2 to +12.9 permil for treated sewage effluent, +30 permil for uncontaminated ground water, -2.0 to +0.7 permil for nitrogen fertilizers, +7.2 to +11.2 permil for manure-based fertilizers, and +39 permil for seawater (Vengosh and others, 1994; Komor, 1997; Barth, 1998). Because of the application of fertilizers on irrigated lands, as well as other processes, it is likely that water from irrigation-return flow would have a distinctly different isotopic composition than other water sources in a particular area. The combination of both $\delta^{11} \mathrm{~B}$ and $\delta^{87} \mathrm{Sr}$ values in water can be a powerful dual isotopic source identification technique that may differentiate dissolved-solids sources better than the use of each isotope independently.

Water samples from selected sites in the Green River study area were collected and analyzed for boron, $\delta^{11} \mathrm{~B}$, strontium, and $\delta^{87} \mathrm{Sr}$ (table 10). Samples were selected to represent what might be considered end members. The canal samples represent the initial source of irrigation water. Samples collected from drains represent a mixture that may include deep percolation of irrigation water, irrigation tail water, and regional ground water. Samples collected from wells may represent either regional ground water unaffected by irrigation, deep percolation of irrigation water, or a mixture of both. Among these sample types there was a wide range in concentrations of strontium and boron as well as in the isotope ratios.

The variation of $\delta^{87} \mathrm{Sr}$ with strontium concentration indicates some general patterns that help to distinguish sources of water and geochemical processes (fig. 8). Canal and river samples had concentrations of strontium that were less than $850 \mu \mathrm{g} / \mathrm{L}$, and the most positive (heavier) $\delta^{87} \mathrm{Sr}$ values, ranging

Table 10. Site characteristics, chemical concentration, isotope ratios, and specific conductance of samples collected from selected sites near Green River, Utah

[ $\mu \mathrm{g} / \mathrm{L}$, micrograms per liter; permil, per thousand; ng/L, nanograms per liter; $\mu \mathrm{S} / \mathrm{cm}$, microsiemens per centimeter; ${ }^{\circ} \mathrm{C}$, degrees Celsius; NA, not applicable]

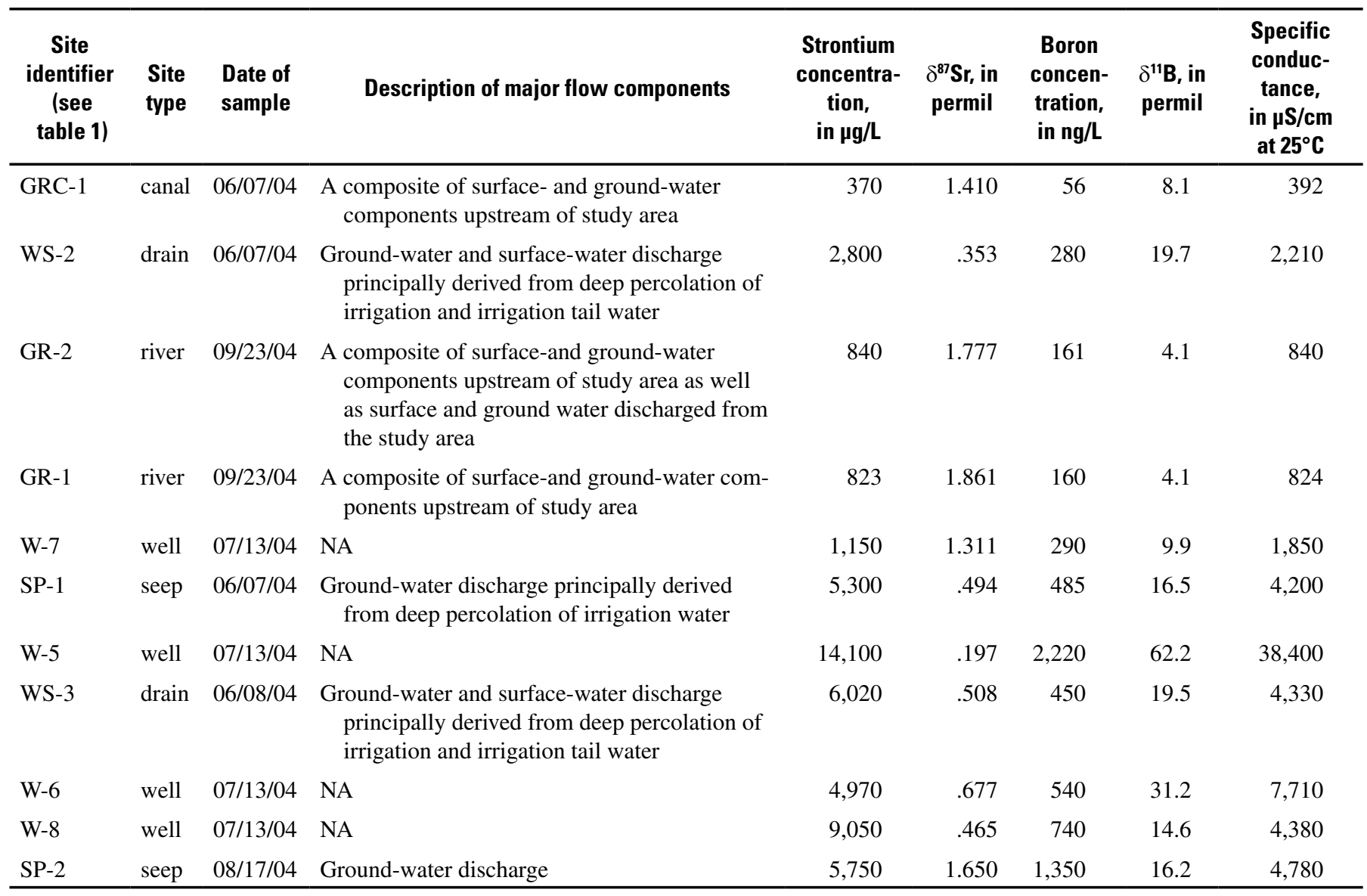




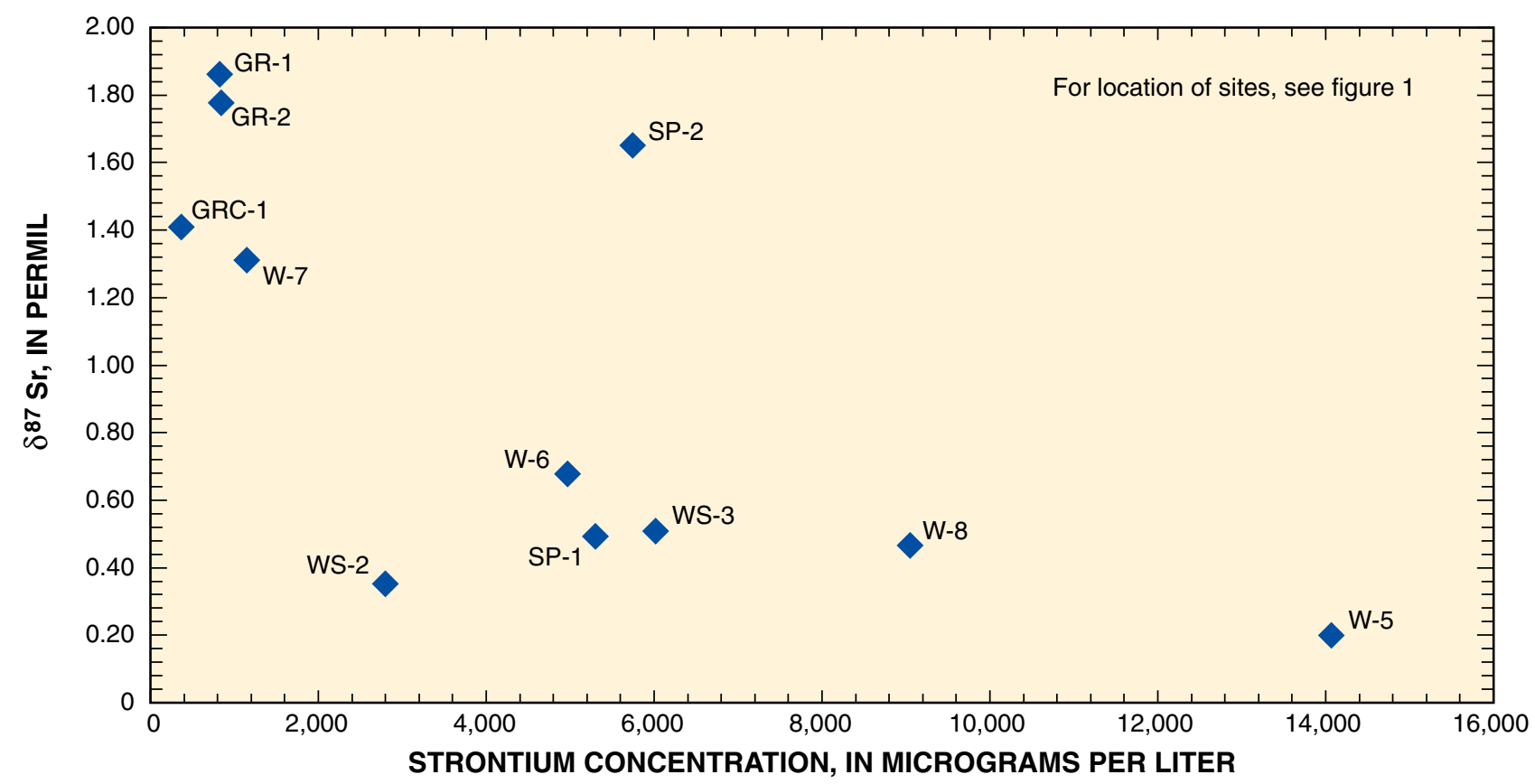

Figure 8. Variation of $\delta^{87} \mathrm{Sr}$ with strontium concentration in samples collected from selected water-quality monitoring sites near Green River, Utah.

from +1.410 to +1.861 permil. Drains and seeps had a wide range of strontium concentrations, from 2,800 to $6,020 \mu \mathrm{g} / \mathrm{L}$, but $\delta^{87} \mathrm{Sr}$ values that generally were less positive (lighter) as compared to the canal and river samples.

The distribution of $\delta^{87} \mathrm{Sr}$ values as shown in figure 8 can be explained by a conceptual model. As irrigation water from the canals, which may be applied to fields in excess of crop consumptive needs, percolates through and interacts with rocks and soils of the Mancos Shale, the $\delta^{87} \mathrm{Sr}$ value of that water approaches one that typifies a Mancos Shale signature. In this case, that value is probably in the range of +0.19 to +0.68 permil. At the same time, strontium is being leached from Mancos Shale and concentrated by evapotranspiration so that the concentration of strontium in water samples from most seeps, drains, and wells is much higher relative to that in water samples collected from canals.

Water from site SP-2 had a much heavier isotopic ratio than water from other seeps and drains. Site SP-2 is a riverbank seep adjacent to the Green River and located immediately upstream of the most northern agricultural field in the Green River area. The $\delta^{87} \mathrm{Sr}$ value for water from site SP-2 indicates that the seep may have been discharging surface runoff stored in the river bank. The elevated strontium concentration indicates that the water has undergone some evaporation during bank storage. None of the other samples from seeps or drains fall between the $\delta^{87} \mathrm{Sr}$ value for SP-2 and values for canal or river water samples (fig. 8). Hence, SP-2 does not appear to represent a regional ground-water flow component.

The $\delta^{87} \mathrm{Sr}$ values associated with water from wells in the study area support the conceptual model previously proposed. Most water from these wells had $\delta^{87} \mathrm{Sr}$ values in the range of +0.197 to +0.677 permil. Water from well $\mathrm{W}-7$ had a $\delta^{87} \mathrm{Sr}$ value of +1.311 , which is much heavier than values of water collected from the other wells. Well W-7 is located close to the river and the $\delta^{87} \mathrm{Sr}$ value indicates some hydraulic connectivity with the river.

A source representing regional ground water discharged to the Green River in the study area was not observed or sampled. The strontium concentration and $\delta^{87} \mathrm{Sr}$ isotope ratio data collected during this study are insufficient to develop a complete mixing model; however, the distribution of the data in figure 8 indicates that there probably is no substantial regional ground-water component.

Boron stable isotope ratios do not vary systematically like strontium ratios. Instead, values of $\delta^{11} \mathrm{~B}$ more likely represent sources of boron, although only a few potential sources can be discerned relative to reported ranges in the literature. The boron ratios from wells W-6 and W-5 fall into the range reported for uncontaminated ground water and seawater. Wells W-5 and W-6 are located in an area that is very poorly drained and which may be a small closed basin. The more positive isotopic ratios for these samples may be the result of extensive evapotransporation, a process that has had a lesser effect on water from seeps and drains. In general, samples with more positive $\delta^{11} \mathrm{~B}$ ratios tend to have higher boron concentrations (fig. 9).

Further study of the variation in strontium and boron concentrations and isotope ratios may provide a means to distinguish end members and further discern processes affecting dissolved solids within the Green River study area; however, the results from data collected during this study for determining end members are inconclusive. The data do not support a definitive mixing model distinguishing dissolved solids associated with a regional ground-water component from those 


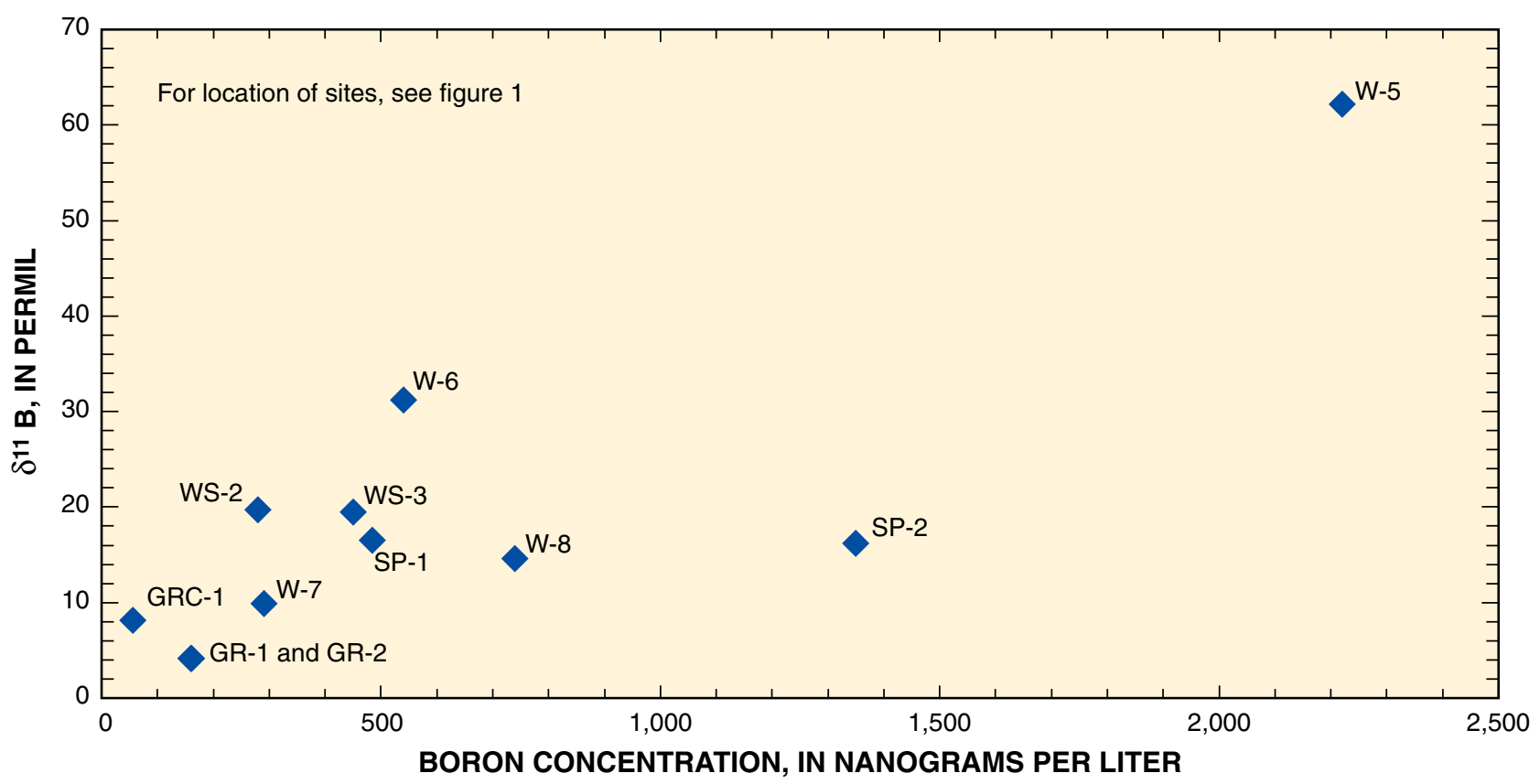

Figure 9. Variation of $\delta^{11} \mathrm{~B}$ with boron concentration in samples collected from selected water-quality monitoring sites near Green River, Utah.

associated with irrigation return flow or identify a regional ground-water source of dissolved solids. Sampling spatially along drains as well as additional end-member sampling, such as water from deep wells or seeps in non-agricultural areas outside the study area, could be valuable and may provide additional data that would help quantify the dissolved solids contributed to the Green River from various components of flow. Additionally, samples for tritium and stable isotopes of hydrogen and oxygen would provide information on end members, potential mixing, and evaporation.

\section{Hydrology of Canals}

A dissolved-solids/water budget for the agricultural areas near Green River could provide a tool for estimating the annual dissolved-solids load being discharged from this area to the Green River. Development of this budget is beyond the scope of this study; however, measurements and calculations of canal flow and seepage made during this study, as well as data collected by local and State agencies, provide some of the required components of a dissolved-solids/water budget. Estimates of average discharge at or near the head of the Thayn Canal, East Side Canal, and Green River Canal were calculated on the basis of instantaneous discharge measurements made by USGS and canal company personnel, and daily mean discharge values obtained from the Utah Division of Water Rights (Utah Division of Water Rights, 2005). The number of days that canals in the Green River area flow varies from year to year and among the canals so total discharge at the head of these canals was estimated for a common period. The frost-free period in the Green River area, May 2 to October 4, (Western Region Climate Center, 2005) was chosen.

\section{Flow}

Water for the Thayn Canal is pumped from a diversion provided by the Tusher low-head dam (fig. 1) and raceway, at about the same location as the head gate for the Green River Canal. A 4-ft Parshall flume is installed near the head of the Thayn Canal. A float-driven shaft encoder and datalogger monitor stage, from which discharge is calculated from a standard 4-ft Parshall flume rating. A record of daily mean discharge is available from the Utah Division of Water Rights for June 2, 2003, to October 28, 2003, and May 6, 2004, to October 31, 2004 (Utah Division of Water Rights, 2005). Data for both periods were used to calculate an estimate of the average daily mean discharge in the Thayn Canal. Discharge measurements made on June 21, 2005, and August 29, 2005 (table 11), show that the actual flow in the flume at the head of the Thayn Canal is about 15 percent greater than the rating for a 4$\mathrm{ft}$ Parshall flume so the daily mean discharge values acquired from the Utah Division of Water Rights were increased 15 percent. The adjusted daily mean discharge is shown in figure 10. For June 2, 2003, to October 28, 2003, and May 6, 2004, to October 31, 2004, the average daily mean discharge in the Thayn Canal was 20.7 and $21.6 \mathrm{ft}^{3} / \mathrm{s}$, respectively. The average daily mean discharge for both periods was $21.2 \mathrm{ft}^{3} / \mathrm{s}$. This value is assumed to represent average flow in the canal for all periods. The estimated total discharge at the head of the Thayn Canal from May 2 to October 4 in any given year is 6,600 acre-ft (table 12). 
Table 11. Stage and discharge measured in the Thayn, East Side, and Green River Canals near Green River, Utah

$\left[\mathrm{ft}^{3} / \mathrm{s}\right.$, cubic feet per second;,- , no data]

\begin{tabular}{|c|c|c|c|}
\hline Date & $\begin{array}{l}\text { Gage height, } \\
\text { in feet }\end{array}$ & $\begin{array}{l}\text { Measured } \\
\text { discharge, } \\
\text { in } \mathrm{ft}^{3} / \mathrm{s}\end{array}$ & $\begin{array}{l}\text { Estimated } \\
\text { discharge } \\
\text { from rating, } \\
\text { in } \mathrm{ft}^{3} / \mathrm{s}\end{array}$ \\
\hline \multicolumn{4}{|c|}{ Thayn Canal at flume (site TC-1) } \\
\hline $07 / 13 / 04$ & 1.35 & - & ${ }^{1} 25.7$ \\
\hline 06/07/05 & .95 & - & - \\
\hline $06 / 20 / 05$ & 1.06 & - & - \\
\hline $06 / 21 / 05$ & 1.05 & ${ }^{2} 19.8$ & ${ }^{1} 17.3$ \\
\hline $08 / 29 / 05$ & .84 & ${ }^{2} 14.1$ & ${ }^{1} 12.2$ \\
\hline \multicolumn{4}{|c|}{ East Side Canal at head (site ESC-1) } \\
\hline $05 / 13 / 04$ & - & ${ }^{2} 20$ & - \\
\hline 06/09/04 & - & ${ }^{2} 25$ & - \\
\hline $07 / 14 / 04$ & - & ${ }^{2} 17$ & - \\
\hline $08 / 29 / 05$ & - & ${ }^{2} 16$ & - \\
\hline \multicolumn{4}{|c|}{ Green River Canal at head (site GRC-1) } \\
\hline 06/07/04 & 3.58 & ${ }^{2} 60.4$ & - \\
\hline $07 / 13 / 04$ & 3.07 & - & ${ }^{3} 52.3$ \\
\hline $09 / 21 / 04$ & 3.15 & - & ${ }^{3} 54.4$ \\
\hline $05 / 27 / 05$ & - & ${ }^{4} 76$ & - \\
\hline 06/05/05 & - & ${ }^{4} 76$ & - \\
\hline 06/07/05 & 3.94 & - & ${ }^{3} 77.3$ \\
\hline 06/07/05 & - & ${ }^{4} 77$ & - \\
\hline $06 / 12 / 05$ & - & ${ }^{4} 65$ & - \\
\hline $06 / 20 / 05$ & 3.40 & - & ${ }^{3} 61.4$ \\
\hline $06 / 21 / 05$ & 3.46 & ${ }^{2} 66.1$ & ${ }^{3} 63.1$ \\
\hline $06 / 21 / 05$ & 3.44 & ${ }^{2} 62.5$ & ${ }^{3} 62.5$ \\
\hline $06 / 26 / 05$ & - & ${ }^{4} 71$ & - \\
\hline $07 / 04 / 05$ & - & ${ }^{4} 67$ & - \\
\hline 07/09/05 & - & ${ }^{4} 59$ & - \\
\hline $07 / 17 / 05$ & - & ${ }^{4} 60$ & - \\
\hline $07 / 24 / 05$ & - & ${ }^{4} 66$ & - \\
\hline $07 / 31 / 05$ & - & ${ }^{4} 64$ & - \\
\hline 08/07/05 & - & ${ }^{4} 67$ & - \\
\hline $08 / 12 / 05$ & - & ${ }^{4} 61$ & - \\
\hline 08/19/05 & - & ${ }^{4} 53$ & - \\
\hline $08 / 26 / 05$ & - & ${ }^{4} 55$ & - \\
\hline $08 / 29 / 05$ & 2.67 & ${ }^{2} 42$ & ${ }^{3} 42$ \\
\hline $09 / 05 / 05$ & - & ${ }^{4} 63$ & - \\
\hline 09/10/05 & - & ${ }^{4} 65$ & - \\
\hline $09 / 16 / 05$ & - & ${ }^{4} 52$ & - \\
\hline \multicolumn{4}{|c|}{ Green River Canal at tail (site GRC-3) } \\
\hline 06/08/04 & - & ${ }^{2} 12.5$ & - \\
\hline $09 / 21 / 04$ & - & ${ }^{2} 13$ & - \\
\hline
\end{tabular}

${ }^{1}$ Discharge from standard rating for 4-ft Parshall flume.

${ }^{2}$ Discharge measured by U.S. Geological Survey (USGS) personnel.

${ }^{3}$ Discharge from rating developed from USGS measurements made during June 2004-August 2005.

${ }^{4}$ Discharge reported by Green River Canal Company.
Water for the East Side Canal is diverted from the east end of the Tusher low-head dam. There is no discharge measuring device on the canal; however, during this study, four discharge measurements were made at the head of the canal (table 11). These measurements were made between May 2004 and August 2005, ranged from 16 to $25 \mathrm{ft}^{3} / \mathrm{s}$, and averaged $19.5 \mathrm{ft}^{3} / \mathrm{s}$. This value is assumed to represent average flow in the canal for all periods. Consequently, the estimated total discharge at the head of the East Side Canal from May 2 to October 4 in any given year is 6,070 acre-ft (table 12).

Water is diverted into the Green River Canal from the Green River by the Tusher low-head dam. Flow control in the Green River Canal is maintained by head gates located about $1.5 \mathrm{mi}$ from the dam. No daily discharge record was compiled during this study; however, 15 measurements of stage and (or) flow were made at the head of the Green River Canal between June 7, 2004, and September 16, 2005 (table 11). The average discharge, as calculated from these measurements, was 63.8 $\mathrm{ft}^{3} / \mathrm{s}$. This value is assumed to represent average discharge in the canal for all periods. The estimated total discharge at the head of the Green River Canal for the period May 2 to October 4 in any given year is 19,900 acre-ft (table 12).

Spillage at the tail of the canal and through sand sluice drains is necessary for proper canal operation. On the basis of two discharge measurements of Green River Canal tail water and one measurement at a sand sluice drain, the estimated spillage from the Green River Canal was about $16 \mathrm{ft}^{3} / \mathrm{s}$ or about 32 acre-ft/d.

\section{Seepage}

Seepage investigations were conducted along a $3.5 \mathrm{mi}$ reach of the Thayn Canal on June 21, 2005, and along a 6.1 mi reach of the Green River Canal on June 22, 2005. Measurements of discharge, specific conductance, and water temperature were made at 12 sites on the Thayn Canal and 18 sites on the Green River Canal or diversions from the canal (fig. 11, table 13, at back of report). Seepage investigations typically are done during periods when discharge and stage are steady. The water level in the canals was measured from June 20 to June 23 by using pressure transducers at two sites on the Thayn Canal and three sites on the Green River Canal (fig. 12). Periodic removal of debris from a hydro-power plant intake grate near the head of the canals resulted in variable stage and discharge in the canals. These non-steady conditions of stage and discharge at the point of diversion from the Green River, combined with unknown or unexpected diversions along the canals, created less than ideal conditions for accurate measurement of discharge, computation of losses or gains, and determination of whether the losses or gains exceeded the errors associated with the measurement of discharge.

Seepage gains and losses were calculated for select reaches of the Green River Canal and Thayn Canal (tables 14 and 15 , at back of report). Only measurements that were determined to be representative of the most steady flow conditions 


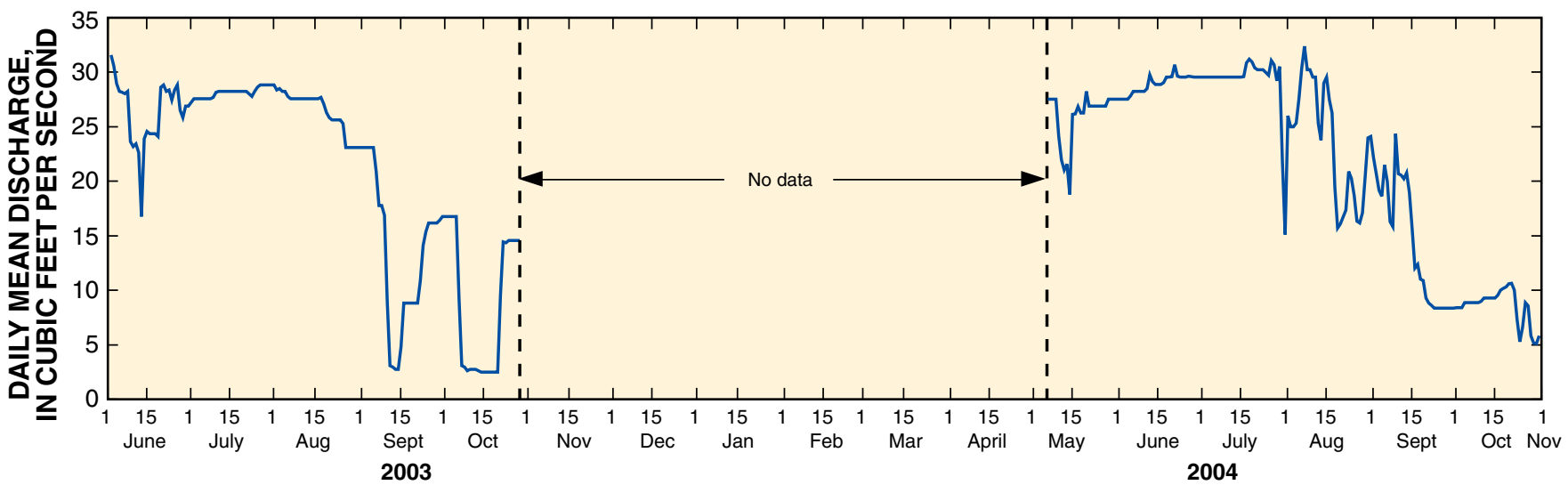

Figure 10. Daily mean discharge in the Thayn Canal, June 2, 2003, to October 31, 2004.

Table 12. Estimated discharge during selected periods at the head of the Thayn, East Side, and Green River Canals near Green River, Utah

[ $\mathrm{ft}^{3} / \mathrm{s}$, cubic feet per second]

\begin{tabular}{|c|c|c|c|c|c|c|c|}
\hline Period & $\begin{array}{l}\text { Number } \\
\text { of days } \\
\text { in period }\end{array}$ & \multicolumn{2}{|c|}{ Thayn Canal } & \multicolumn{2}{|c|}{ East Side Canal } & \multicolumn{2}{|c|}{ Green River Canal } \\
\hline May 2 to October 4 & 157 & 21.2 & 6,600 & 19.5 & 6,070 & 63.8 & 19,900 \\
\hline April 1 to October 31 & 212 & 21.2 & 8,920 & 19.5 & 8,200 & 63.8 & 26,800 \\
\hline
\end{tabular}

were used in these calculations. Losses and gains between discharge-measurement sites on the Green River Canal ranged from -25 to 1 acre-ft/d, respectively. The total measured loss between sites GRC-1 and G9 was 49 acre-ft/d. The loss in reach GRC-1 to G2 was 25 acre-ft/d and probably included losses from undetected diversions. Discharge measurements made at site GRC-1 and GRC-2 (near G2) in June 2004 (table 2) indicated a loss of 5.9 acre-ft/d in this reach, a value that is probably more representative of the actual seepage losses in this reach. By using the seepage loss for reach GRC-1 to G2 measured in June 2004 and the seepage loss in the canal between sites G2 and G9 measured in June 2005, total seepage losses in the Green River Canal between sites GRC-1 and G9 were calculated to be about 30 acre-ft/d. Losses and gains between discharge-measurement sites on the Thayn Canal ranged from -4.4 to 2.8 acre-ft/d, respectively. The total measured loss from the Thayn Canal was 9.9 acre-ft/d, all of which is attributed to seepage.

Most of the seepage gains or losses calculated for these canals were based on differences in discharge that were within the measurement error assigned to the discharge measurements. Therefore, the seepage loss calculated for each canal represents a value that may have considerable associated error and the subsequent calculations of total annual seepage should be viewed with caution. The primary objective in determining seepage in these canals is to quantify the seepage losses contributing to deep percolation. Some reaches appear to have seepage gains, probably resulting from inflow of shallow ground water and surface water draining from fields adjacent to the canal. Seepage losses may be obscured by concurrent ground-water inflow or surface-water gains. No seepage measurements were made on the lower $2 \mathrm{mi}$ of the Green River Canal; therefore, the daily and annual seepage from the canal should be considered a conservative estimate of the contribution to deep percolation.

The seepage losses or gains determined on June 21 and 22, 2005, for the Thayn and Green River Canals, respectively, are indicative of the flow conditions, diversion settings and locations, and soil-moisture content that preceded the seepage investigations. Seepage investigations undertaken at a time of the year when the canal stage is stable and diversions are closed could yield different results.

The estimated seepage loss from the Thayn, East Side, and Green River Canals for the period May 2 to October 4 is 


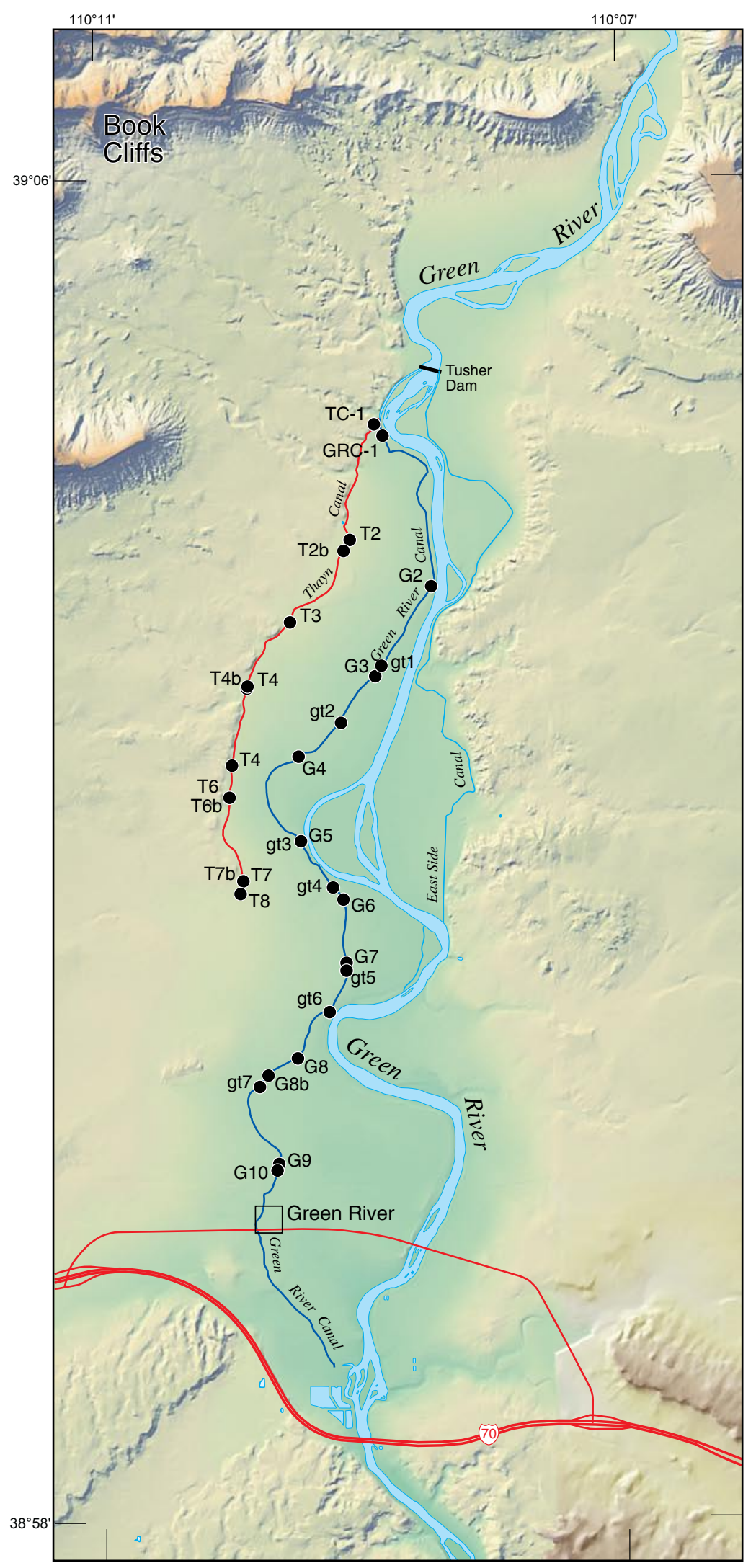

\section{EXPLANATION}

G10 Discharge-measurement site

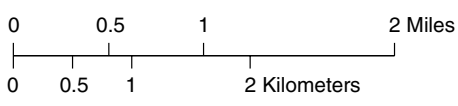

Figure 11. Sites where discharge was measured on the Thayn and Green River Canals near Green River, Utah, during June 20-23, 2005. 


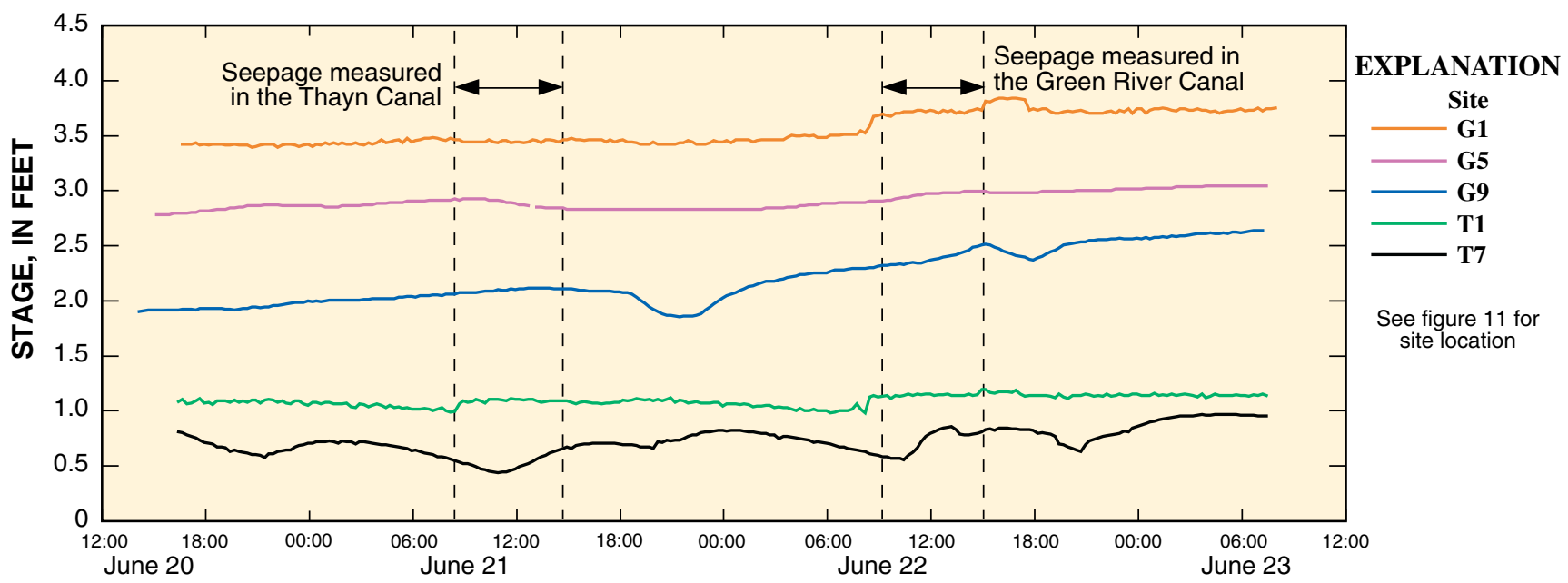

Figure 12. Stage in Thayn and Green River Canals, June 20-23, 2005.

Table 16. Estimated seepage loss from the Thayn, East Side, and Green River Canals near Green River, Utah

$[-$, no data; e, estimated $]$

\begin{tabular}{lccccc}
\hline \multicolumn{1}{c}{ Canal } & $\begin{array}{c}\text { Estimated seep- } \\
\text { age loss, in acre- } \\
\text { feet per day }\end{array}$ & $\begin{array}{c}\text { Days of } \\
\text { canal flow }{ }^{1}\end{array}$ & $\begin{array}{c}\text { Estimated } \\
\text { seepage } \\
\text { loss, } \\
\text { in acre-feet }\end{array}$ & $\begin{array}{c}\text { Estimated } \\
\text { canal inflow, } \\
\text { in acre-feet }\end{array}$ & $\begin{array}{c}\text { Estimated } \\
\text { seepage loss, } \\
\text { in percent of } \\
\text { inflow }\end{array}$ \\
\hline Thayn Canal & 9.9 & 157 & 1,550 & 6,600 & 23 \\
East Side Canal & - & 157 & 21,460 & 6,070 & $3 \mathrm{e} 24$ \\
Green River Canal & 30 & 157 & 4,710 & 19,900 & 24 \\
\hline
\end{tabular}

${ }^{1}$ Number of days that canals have flow varies from year to year and among the canals. The number of days contained in the period May 2 to October 4, the frost-free period, are shown here.

${ }^{2}$ Estimated seepage loss, in acre-feet, determined from estimated seepage loss, in percent, and estimated canal flow for the period May 2 to October 4.

${ }^{3}$ Seepage loss percentage is average of calculated seepage loss percentage for Thayn and Green River Canals.

$1,550,1,460$, and 4,710 acre-ft, respectively (table 16). No direct measure of seepage was done on the East Side Canal, so the calculation for annual seepage loss from this canal is based on the average percent of seepage relative to flow in the Green River and Thayn Canals. Estimated annual seepage losses from these canals are about 24 percent of canal inflow.

\section{Summary}

During 2004-05 the U.S. Geological Survey, in cooperation with the Natural Resources Conservation Service, conducted an investigation of the occurrence and distribution of dissolved solids in water from the agricultural areas near Green River, Utah, and in the adjacent reach of the Green
River, a principal tributary of the Colorado River. The agricultural lands surrounding Green River, Utah, have been identified by the Natural Resources Conservation Service as areas contributing dissolved solids to the Green River.

During this study, the concentration of dissolved solids in surface and ground water in the study area ranged from 192 to $55,900 \mathrm{mg} / \mathrm{L}$. Specifically, the concentration of dissolved solids in water samples from the Green River ranged from 214 to $569 \mathrm{mg} / \mathrm{L}$. The dissolved-solids concentration in samples from seeps ranged from 1,680 to $5,080 \mathrm{mg} / \mathrm{L}$, and the dissolved-solids concentration in water from the shallow part of the ground-water system ranged from 687 to $55,900 \mathrm{mg} / \mathrm{L}$.

The flow-weighted concentration of dissolved solids diverted from the Green River for irrigation during 2004 and 2005 was $357 \mathrm{mg} / \mathrm{L}$ and the mean concentration of water collected from seeps and drains where water was returning to the 
river during low-flow conditions was $4,170 \mathrm{mg} / \mathrm{L}$. Assuming no mixing with a concentrated regional source of dissolved solids, the increase in dissolved solids as a result of processes occurring along the flow path followed by deep percolation was $3,810 \mathrm{mg} / \mathrm{L}$ or 5.2 tons of dissolved solids per acre-ft of deep percolation.

The median dissolved-solids load from the 17 drains or seeps visited during the study was 0.35 ton/d. The dissolvedsolids load from these sites ranged from less than 0.1 to 7.5 tons/d. Paired measurements of dissolved-solids concentration at sites on the Green River upstream and downstream of the study area were analyzed to determine an estimate of the dissolved-solids load being discharged to the Green River in the intervening reach. These estimates varied from 7 to 69 tons/d. An estimated 15,700 tons of dissolved solids were discharged from the study area between June 1, 2004, and May 31, 2005. Estimates of the dissolved-solids load discharging from the study area seasonally range from 2,800 tons in the winter to 6,400 tons in the spring.

Water samples from selected sites in the Green River study area were collected and analyzed for boron, delta boron$11\left(\delta^{11} \mathrm{~B}\right)$, strontium, and delta strontium-87 $\left(\delta^{87} \mathrm{Sr}\right)$. Canal and river samples had relatively low concentrations of strontium and the most positive (heavier) $\delta^{87} \mathrm{Sr}$ values, while samples from drains and seeps had a wide range of strontium concentrations, but $\delta^{87} \mathrm{Sr}$ values that generally were less positive (lighter) than the river and canals. Further study of the variation in strontium and boron concentrations and isotope ratios may provide a means to distinguish end members and discern processes affecting dissolved solids within the Green River study area; however, the results from data collected during this study for determining end members are inconclusive.

Flow and seepage losses were estimated for the three main canals in the study area for May 2 to October 4. This period coincides with the frost-free period in the Green River area. Estimated diversion from the Green River into the Thayn, East Side, and Green River Canals is 6,600, 6,070, and 19,900 acre-feet, respectively. The estimated seepage loss to ground water from the Thayn, East Side, and Green River Canals for the same period is $1,550,1,460$, and 4,710 acrefeet, respectively.

\section{References Cited}

Barbieri, M., and Morotti, M., 2003, Hydrogeochemistry and strontium isotopes of spring and mineral waters from Monte Vulture volcano, Italy: Applied Geochemistry, v. 18, p. 117125 .

Barth, S., 1998, Application of boron isotopes for tracing sources of anthropogenic contamination in groundwater: Water Resources, v. 32, p. 685-690.
Buchanan, T.J., and Somers, W.P., 1969, Discharge measurements at gaging stations: U.S. Geological Survey Techniques of Water-Resources Investigations, book 3, chap. A8, $65 \mathrm{p}$.

Enright, Michael, Wilberg, D.E., and Tibbetts, J.R., 2005, Water Resources Data, Utah, Water Year 2004: U.S. Geological Survey Water-Data Report UT-04-1, 428 p.

Fishman, M.J., and Friedman, L.C., 1989, Methods for determination of inorganic substances in water and fluvial sediments: U.S. Geological Survey Techniques of WaterResources Investigations, book 5, chap. A1, 545 p.

Geary, E.A., 1996, A history of Emery County: Salt Lake City, Utah, Utah State Historical Society [and] Emery County Commission, 448 p.

Hedlund, J.D., 1994, Salt primer - Water and salt budgets: Portland, Oregon, Soil Conservation Service, West National Technical Center, 60 p.

Hemphill, L.S., 2005, Water atlas of Utah, Class A pan evaporation for Utah, May - October, 1956-1970, accessed May 2005 at http://www.engineering.usu.edu/uwrl/atlas/ch3/ index.html

Komor, S.C., 1997, Boron contents and isotopic composition of hog manure, selected fertilizers, and water in Minnesota: Journal of Environmental Quality, v. 26, p. 1212-1222.

Naftz, D.L., Peterman, Z.E., and Spangler, L.E., 1997, Using $\delta^{87} \mathrm{Sr}$ values to identify sources of salinity to a freshwater aquifer, Greater Aneth Oil Field, Utah, U.S.A.: Chemical Geology, v. 141, p. 195-209.

Nimz, G.J., Smith, D.K., Caffee, M.W., Finkel, R.C., Hudson, G.B., Borchers, J.W., and Nimz, K.P., 1992, Isotope characterization of hydrologic structure and chemical interaction between groundwater and granitic rock in the Wawona Basin, Yosemite National Park: Eos, Transactions, American Geophysical Union, v. 73, p. 170.

Radtke, D.B., Davis, J.B., and Wilde, F.D, eds., August 2005, Specific electrical conductance field measurement: U.S. Geological Survey Techniques of Water-Resources Investigations, book 9, chap. A6.3, accessed January 2006 at http://water.usgs.gov/owq/FieldManual/Chapter6/6.3_contents.html

Robinson, T.W., 1958, Phreatophytes: U.S. Geological Survey Water-Supply Paper 1423, 84 p.

Simpson, M.R., 2002, Discharge measurements using a broadband acoustic Doppler current profiler: U.S. Geological Survey Open-File Report 2001-1, 123 p. 
Spangler, L.E., Naftz, D.L., and Peterman, Z.E., 1996, Hydrology, chemical quality, and characterization of salinity in the Navajo aquifer in and near the Greater Aneth Oil Field, San Juan County, Utah: U.S. Geological Survey WaterResources Investigations Report 96-4155, 90 p.

U.S. Department of Agriculture, 2006, digital land cover data obtained from the National Agricultural Imagery Program, accessed January 2006 at http://agrc.its.state.ut.us/agrc sgid/naip.html

U.S. Department of the Interior, 2003, Quality of water - Colorado River Basin: Salt Lake City, Utah, Bureau of Reclamation, Upper Colorado Region, Progress report no. 21,83 p. plus appendix.

U.S. Geological Survey, 2006, National Land Cover Dataset, accessed January 2006 at http://landcover.usgs.gov/natllandcover.php

Utah Division of Water Rights, 2005, Water distribution database, data accessed September 2005 at http://waterrights. utah.gov/cgi-bin/dvrtview.exe

Vengosh, A., Heumann, K.G., Juraske, S., and Kasher, R., 1994, Boron isotope application for tracing sources of contamination in groundwater: Environmental Science and Technology, v. 28, p. 1968-1974.

Webb, W.E., Radtke, D.B., and Iwatsubo, R.T., September 1999, Surface-water sampling: Collection methods at flowing-water and still-water sites: U.S. Geological Survey Techniques of Water-Resources Investigations, book 9, chap. A4.1, accessed January 2006 at http://water.usgs. gov/owq/FieldManual/chapter4/html/4.1_contents.html

Western Regional Climate Center, 2005, Period of record monthly climate summary for Green River Aviation (423418), accessed May 2005 at http:/www.wrcc.dri.edu/ cgi-bin/cliMAIN.pl?utgree

Wilberg, D.E., Swenson, R.L., Slaugh, B.A., Howells, J.H., and Christiansen, H.K., 2001, Seepage investigation for Leap, South Ash, Wet Sandy, and Leeds Creek in the Pine Valley Mountains, Washington County, Utah, 1998: U.S. Geological Survey Water-Resources Investigations Report 01-4237, $42 \mathrm{p}$.

Wilberg, D.E., Tibbetts, J.R., Enright, Michael., Burden, C.B., Smith, Cynthia, and Angeroth, C.E., 2006, Water Resources Data, Utah, Water Year 2005: U.S. Geological Survey Water-Data Report UT-05-1, 733 p. 
Table 2. Properties of water samples collected from water-quality monitoring sites near Green River, Utah

$\left[\mathrm{ft} / \mathrm{s}\right.$, cubic feet per second; $\mu \mathrm{S} / \mathrm{cm}$, microsiemens per centimeter; ${ }^{\circ} \mathrm{C}$, degrees Celsius; $\mathrm{mg} / \mathrm{L}$, milligrams per liter; ROE, residue on evaporation at $180^{\circ} \mathrm{C} ; \mathrm{NA}$, not applicable; - - no data; e, estimated; <, less than]

\begin{tabular}{|c|c|c|c|c|c|c|c|c|}
\hline $\begin{array}{c}\text { Site } \\
\text { identifier } \\
\text { (see } \\
\text { table 1) }\end{array}$ & $\begin{array}{c}\text { U.S. } \\
\text { Geological } \\
\text { Survey } \\
\text { site } \\
\text { identification } \\
\text { number }\end{array}$ & $\begin{array}{l}\text { Site } \\
\text { type }\end{array}$ & $\begin{array}{c}\text { Sample } \\
\text { date }\end{array}$ & $\begin{array}{c}\text { Sample } \\
\text { time }\end{array}$ & $\begin{array}{c}\text { Water level, } \\
\text { below land } \\
\text { surface } \\
\text { (feet) }\end{array}$ & $\begin{array}{l}\text { Discharge, } \\
\text { instan- } \\
\text { taneous } \\
\left(\mathrm{ft}^{3} / \mathrm{s}\right)\end{array}$ & $\begin{array}{c}\text { pH, water, } \\
\text { unfiltered, } \\
\text { laboratory } \\
\text { (standard } \\
\text { units) }\end{array}$ & $\begin{array}{c}\text { Specific } \\
\text { conduc- } \\
\text { tance, } \\
\text { water, } \\
\text { unfiltered, } \\
\text { laboratory } \\
(\mu \mathrm{S} / \mathrm{cm} \text { at } \\
\left.25^{\circ} \mathrm{C}\right)\end{array}$ \\
\hline \multirow[t]{13}{*}{ GR-1 } & 390608110070601 & river & $03 / 14 / 04$ & 1200 & NA & - & - & - \\
\hline & & & 06/07/04 & 1730 & NA & - & - & - \\
\hline & & & $07 / 14 / 04$ & 1734 & NA & - & - & 一 \\
\hline & & & 08/17/04 & 1115 & NA & 1,220 & 8.3 & 739 \\
\hline & & & 09/10/04 & 0745 & NA & - & - & - \\
\hline & & & 09/23/04 & 1200 & NA & 1,550 & 8.1 & 769 \\
\hline & & & $10 / 14 / 04$ & 1215 & NA & 2,080 & 8.2 & 581 \\
\hline & & & $11 / 16 / 04$ & 1340 & NA & 2,760 & 8.2 & 797 \\
\hline & & & $12 / 14 / 04$ & 1500 & NA & 2,650 & - & - \\
\hline & & & $12 / 15 / 04$ & 1200 & NA & 2,720 & - & - \\
\hline & & & $12 / 15 / 04$ & 1530 & NA & 2,670 & 8.2 & 770 \\
\hline & & & 02/10/05 & 0920 & NA & - & - & - \\
\hline & & & $03 / 31 / 05$ & 1440 & NA & 3,220 & - & - \\
\hline \multirow[t]{20}{*}{ GR-2 } & 09315000 & river & $04 / 09 / 04$ & 0815 & NA & 4,000 & - & - \\
\hline & & & $05 / 14 / 04$ & 1400 & NA & 11,100 & - & 一 \\
\hline & & & $06 / 02 / 04$ & 0815 & NA & 5,640 & - & - \\
\hline & & & 07/13/04 & 0815 & NA & 2,160 & - & - \\
\hline & & & $07 / 13 / 04$ & 1850 & NA & 2,050 & - & - \\
\hline & & & $07 / 14 / 04$ & 1805 & NA & 1,930 & - & - \\
\hline & & & 08/17/04 & 1700 & NA & 1,180 & 8.3 & 753 \\
\hline & & & 08/30/04 & 1030 & NA & 1,230 & - & - \\
\hline & & & 09/10/04 & 0817 & NA & 1,640 & - & - \\
\hline & & & 09/23/04 & 1615 & NA & 1,550 & 8.2 & 816 \\
\hline & & & $10 / 14 / 04$ & 1550 & NA & 2,070 & 8.2 & 595 \\
\hline & & & $11 / 16 / 04$ & 1605 & NA & 2,700 & 8.2 & 788 \\
\hline & & & $12 / 14 / 04$ & 1700 & NA & 2,470 & - & - \\
\hline & & & $12 / 16 / 04$ & 0745 & NA & 2,230 & - & - \\
\hline & & & $01 / 25 / 05$ & 1100 & NA & 2,840 & - & - \\
\hline & & & $02 / 10 / 05$ & 1048 & NA & 2,690 & - & - \\
\hline & & & $03 / 18 / 05$ & 0830 & NA & 3,440 & - & - \\
\hline & & & $03 / 31 / 05$ & 1650 & NA & 3,200 & - & - \\
\hline & & & $04 / 01 / 05$ & 1020 & NA & 3,070 & - & - \\
\hline & & & $05 / 04 / 05$ & 0840 & NA & 9,820 & - & - \\
\hline \multirow[t]{2}{*}{ ESC-1 } & 390446110082401 & canal & 03/13/04 & 1230 & NA & $\mathrm{e} 20$ & - & 一 \\
\hline & & & 06/09/04 & 0850 & NA & 25 & - & 一 \\
\hline
\end{tabular}


Table 2. Properties of water samples collected from water-quality monitoring sites near Green River, Utah—Continued

\begin{tabular}{|c|c|c|c|c|c|c|c|c|c|}
\hline $\begin{array}{c}\text { Site } \\
\text { identifier } \\
\text { (see } \\
\text { table 1) }\end{array}$ & $\begin{array}{c}\text { Specific } \\
\text { conduc- } \\
\text { tance, } \\
\text { water, field, } \\
\text { unfiltered } \\
(\mu \mathrm{S} / \mathrm{cm} \text { at } \\
\left.25^{\circ} \mathrm{C}\right)\end{array}$ & $\begin{array}{c}\text { Temper- } \\
\text { ature, } \\
\text { water } \\
\left({ }^{\circ} \mathrm{C}\right)\end{array}$ & $\begin{array}{l}\text { Hard- } \\
\text { ness, } \\
\text { water } \\
(\mathrm{mg} / \mathrm{L} \text { as } \\
\left.\mathrm{CaCO}_{3}\right)\end{array}$ & $\begin{array}{l}\text { Alkalinity, } \\
\text { water, } \\
\text { filtered, in- } \\
\text { cremental } \\
\text { titration, } \\
\text { lab } \\
\text { (mg/L) }\end{array}$ & $\begin{array}{l}\text { Dissolved- } \\
\text { solids } \\
\text { concentration, } \\
\text { sum of } \\
\text { constituents, } \\
\text { water, } \\
\text { filtered } \\
\text { (mg/L) }\end{array}$ & $\begin{array}{l}\text { Dissolved- } \\
\text { solids } \\
\text { concentration, } \\
\text { ROE, } \\
\text { water, filtered } \\
\text { (mg/L) }\end{array}$ & $\begin{array}{l}\text { ROE/ } \\
\text { Specific } \\
\text {-conduc- } \\
\text { tance } \\
\text { ratio }\end{array}$ & $\begin{array}{l}\text { Dissolved- } \\
\text { solids } \\
\text { concentra- } \\
\text { tion, from } \\
\text { ROE/Specific- } \\
\text { conductance } \\
\text { ratio } \\
\text { (mg/L) }\end{array}$ & $\begin{array}{c}\text { Dis- } \\
\text { solved- } \\
\text { solids } \\
\text { load } \\
\text { (tons per } \\
\text { day) }\end{array}$ \\
\hline \multirow[t]{13}{*}{ GR-1 } & 344 & 14.7 & - & - & - & - & ${ }^{1} 0.64$ & 220 & - \\
\hline & 395 & 23.6 & - & - & - & - & ${ }^{1} .64$ & 253 & - \\
\hline & 561 & 26.5 & - & - & - & - & ${ }^{1} .64$ & 359 & - \\
\hline & 785 & 23.9 & 250 & 163 & 484 & 502 & .64 & 502 & 1,650 \\
\hline & 742 & 19.1 & - & - & - & - & ${ }^{1} .64$ & 475 & - \\
\hline & 824 & 14.6 & 270 & 167 & 521 & 536 & .65 & 536 & 2,240 \\
\hline & 634 & 14.0 & 220 & 138 & 384 & 401 & .63 & 401 & 2,250 \\
\hline & 822 & 7.8 & 260 & 168 & 530 & 538 & .65 & 538 & 4,000 \\
\hline & 830 & 1.2 & - & - & - & - & ${ }^{1} .64$ & 531 & 3,800 \\
\hline & 820 & .6 & - & - & - & 521 & .64 & 521 & 3,820 \\
\hline & 805 & 1.1 & 290 & 174 & 501 & 511 & .63 & 511 & 3,680 \\
\hline & 886 & 2.7 & - & - & - & - & ${ }^{1} .64$ & 567 & - \\
\hline & 849 & 10.1 & - & - & - & 546 & .64 & 546 & 4,740 \\
\hline \multirow[t]{20}{*}{ GR-2 } & 630 & 15.0 & - & - & - & 404 & .64 & 404 & 4,360 \\
\hline & 335 & 15.0 & - & - & - & - & ${ }^{1} .64$ & 214 & 6,410 \\
\hline & 400 & 18.0 & - & - & - & 251 & .63 & 251 & 3,820 \\
\hline & 600 & 24.0 & - & - & - & 366 & .61 & 366 & 2,130 \\
\hline & 580 & 15.0 & - & - & - & - & ${ }^{1} .64$ & 371 & 1,960 \\
\hline & 578 & 28.0 & - & - & - & - & ${ }^{1} .64$ & 370 & 1,930 \\
\hline & 794 & 25.5 & 250 & 163 & 492 & 517 & .65 & 517 & 1,650 \\
\hline & 880 & 20.5 & - & - & - & 555 & .63 & 555 & 1,840 \\
\hline & 750 & 19.2 & - & - & - & - & ${ }^{1} .64$ & 480 & 2,120 \\
\hline & 840 & 16.2 & 270 & 166 & 531 & 546 & .65 & 546 & 2,280 \\
\hline & 646 & 14.7 & 220 & 140 & 392 & 406 & .63 & 406 & 2,270 \\
\hline & 815 & 8.4 & 270 & 168 & 532 & 532 & .65 & 532 & 3,870 \\
\hline & 842 & 2.0 & - & - & - & - & ${ }^{1} .64$ & 539 & 3,590 \\
\hline & 840 & .2 & - & - & - & - & ${ }^{1} .64$ & 538 & 3,240 \\
\hline & 890 & 2.0 & - & - & - & 569 & .64 & 569 & 4,360 \\
\hline & 888 & 3.8 & - & - & - & - & ${ }^{1} .64$ & 568 & 4,120 \\
\hline & 810 & 6.5 & - & - & - & 521 & .64 & 521 & 4,830 \\
\hline & 865 & 11.0 & - & - & - & - & ${ }^{1} .64$ & 554 & 4,780 \\
\hline & 842 & 9.1 & - & - & - & 549 & .65 & 549 & 4,550 \\
\hline & 470 & 14.0 & - & - & - & 289 & .61 & 289 & 7,650 \\
\hline \multirow[t]{2}{*}{ ESC-1 } & 335 & 15.0 & - & - & - & - & ${ }^{1} .64$ & 214 & e11.6 \\
\hline & 428 & 21.7 & - & - & - & - & ${ }^{1} .64$ & 274 & 18.5 \\
\hline
\end{tabular}


Table 2. Properties of water samples collected from water-quality monitoring sites near Green River, Utah-Continued

\begin{tabular}{|c|c|c|c|c|c|c|c|c|}
\hline $\begin{array}{c}\text { Site } \\
\text { identifier } \\
\text { (see } \\
\text { table 1) }\end{array}$ & $\begin{array}{c}\text { U.S. } \\
\text { Geological } \\
\text { Survey } \\
\text { site } \\
\text { identification } \\
\text { number }\end{array}$ & $\begin{array}{l}\text { Site } \\
\text { type }\end{array}$ & $\begin{array}{c}\text { Sample } \\
\text { date }\end{array}$ & $\begin{array}{c}\text { Sample } \\
\text { time }\end{array}$ & $\begin{array}{l}\text { Water level, } \\
\text { below land } \\
\text { surface } \\
\text { (feet) }\end{array}$ & $\begin{array}{l}\text { Discharge, } \\
\text { instan- } \\
\text { taneous } \\
\left(\mathrm{ft}^{3} / \mathbf{s}\right)\end{array}$ & $\begin{array}{l}\text { pH, water, } \\
\text { unfiltered, } \\
\text { laboratory } \\
\text { (standard } \\
\text { units) }\end{array}$ & $\begin{array}{c}\text { Specific } \\
\text { conduc- } \\
\text { tance, } \\
\text { water, } \\
\text { unfiltered, } \\
\text { laboratory } \\
(\mu \mathrm{S} / \mathrm{cm} \text { at } \\
25^{\circ} \mathrm{C} \text { ) }\end{array}$ \\
\hline \multicolumn{2}{|c|}{ ESC-1-Continued } & & 07/14/04 & 1647 & NA & 17 & - & - \\
\hline \multirow[t]{2}{*}{$\mathrm{ESC}-2$} & 390135110082301 & canal & 03/13/04 & 1300 & NA & e4 & - & - \\
\hline & & & 06/09/04 & 0932 & NA & 2.8 & - & - \\
\hline \multirow[t]{5}{*}{ GRC-1 } & 390428110084901 & canal & 06/07/04 & 1445 & NA & 60 & 8.0 & 398 \\
\hline & & & 07/13/04 & 1300 & NA & 52 & - & - \\
\hline & & & 09/21/04 & 0946 & NA & 53 & - & - \\
\hline & & & $11 / 16 / 04$ & 0900 & NA & e2 & - & - \\
\hline & & & 02/10/05 & 1210 & NA & e1 & - & - \\
\hline \multirow[t]{3}{*}{ GRC-2 } & 390314110084301 & canal & 06/07/04 & 1538 & NA & 57 & - & - \\
\hline & & & 07/13/04 & 1324 & NA & - & - & - \\
\hline & & & 09/21/04 & 1055 & NA & - & - & - \\
\hline \multirow[t]{2}{*}{ GRC-3 } & 385917110093601 & canal & 06/08/04 & 1340 & NA & 12 & - & - \\
\hline & & & 09/21/04 & 1620 & NA & 13 & - & - \\
\hline TC-1 & 390433110085201 & canal & 07/13/04 & 1310 & NA & 26 & - & - \\
\hline DCH-1 & 390303110085301 & drain & 06/07/04 & 1810 & NA & .12 & - & - \\
\hline DCH-2 & 390212110092601 & drain & 06/08/04 & 1620 & NA & .01 & - & - \\
\hline DCH-3 & 390214110084901 & drain & $09 / 22 / 04$ & 1441 & $\mathrm{NA}$ & .3 & - & - \\
\hline DCH-4 & 385854110092601 & drain & $09 / 24 / 04$ & 0920 & NA & .76 & - & - \\
\hline \multirow[t]{3}{*}{ DRN-1 } & 385948110083801 & drain & 06/08/04 & 0840 & NA & .1 & - & - \\
\hline & & & 07/07/04 & 0820 & NA & e .1 & - & 一 \\
\hline & & & $09 / 22 / 04$ & 1711 & NA & 2.2 & - & - \\
\hline \multirow[t]{5}{*}{ DRN-2 } & 385917110090401 & drain & 03/13/04 & 0800 & NA & e1 & - & 一 \\
\hline & & & 07/13/04 & 1857 & NA & 3 & - & 一 \\
\hline & & & $09 / 21 / 04$ & 1648 & NA & 1 & - & - \\
\hline & & & $02 / 10 / 05$ & 1053 & NA & .04 & - & - \\
\hline & & & 04/01/05 & 1030 & NA & .05 & - & - \\
\hline SD-1 & 390207110092701 & drain & $09 / 24 / 04$ & 1020 & NA & 3.2 & - & - \\
\hline \multirow[t]{2}{*}{ WS-1 } & 390418110085101 & drain & 07/07/04 & 1200 & NA & $<.01$ & - & - \\
\hline & & & 09/21/04 & 0940 & NA & $<.01$ & - & 一 \\
\hline \multirow[t]{4}{*}{ WS-2 } & 390313110083801 & drain & 06/07/04 & 1850 & NA & .07 & 7.9 & 2,090 \\
\hline & & & 07/07/04 & 1300 & NA & e4 & - & - \\
\hline & & & 09/21/04 & 1200 & NA & .05 & - & - \\
\hline & & & 02/10/05 & 1230 & NA & .02 & - & - \\
\hline \multirow[t]{2}{*}{ WS-3 } & 390233110090001 & drain & 03/14/04 & 0900 & NA & $\mathrm{e} 0.1$ & - & - \\
\hline & & & 06/08/04 & 1600 & NA & .05 & 7.5 & 3,880 \\
\hline
\end{tabular}


Table 2. Properties of water samples collected from water-quality monitoring sites near Green River, Utah-Continued

\begin{tabular}{|c|c|c|c|c|c|c|c|c|c|}
\hline $\begin{array}{c}\text { Site } \\
\text { identifier } \\
\text { (see } \\
\text { table 1) }\end{array}$ & $\begin{array}{c}\text { Specific } \\
\text { conduc- } \\
\text { tance, } \\
\text { water, field, } \\
\text { unfiltered } \\
(\mu \mathrm{S} / \mathrm{cm} \text { at } \\
\left.25^{\circ} \mathrm{C}\right)\end{array}$ & $\begin{array}{l}\text { Temper- } \\
\text { ature, } \\
\text { water } \\
\left({ }^{\circ} \mathrm{C}\right)\end{array}$ & $\begin{array}{l}\text { Hard- } \\
\text { ness, } \\
\text { water } \\
(\mathrm{mg} / \mathrm{L} \text { as } \\
\left.\mathrm{CaCO}_{3}\right)\end{array}$ & $\begin{array}{l}\text { Alkalinity, } \\
\text { water, } \\
\text { filtered, in- } \\
\text { cremental } \\
\text { titration, } \\
\text { lab } \\
\text { (mg/L) }\end{array}$ & $\begin{array}{c}\text { Dissolved- } \\
\text { solids } \\
\text { concentration, } \\
\text { sum of } \\
\text { constituents, } \\
\text { water, } \\
\text { filtered } \\
\text { (mg/L) }\end{array}$ & $\begin{array}{c}\text { Dissolved- } \\
\text { solids } \\
\text { concentration, } \\
\text { ROE, } \\
\text { water, filtered } \\
\text { (mg/L) }\end{array}$ & $\begin{array}{c}\mathrm{ROE} / \\
\text { Specific } \\
\text {-conduc- } \\
\text { tance } \\
\text { ratio }\end{array}$ & $\begin{array}{l}\text { Dissolved- } \\
\text { solids } \\
\text { concentra- } \\
\text { tion, from } \\
\text { ROE/Specific- } \\
\text { conductance } \\
\text { ratio } \\
\text { (mg/L) }\end{array}$ & $\begin{array}{l}\text { Dis- } \\
\text { solved- } \\
\text { solids } \\
\text { load } \\
\text { (tons per } \\
\text { day) }\end{array}$ \\
\hline ESC-1 & 565 & 26.6 & - & - & - & - & ${ }^{1} .64$ & 362 & 16.6 \\
\hline \multirow{2}{*}{ ESC-2 } & 300 & 13.5 & - & - & - & - & ${ }^{1} .64$ & 192 & 2.1 \\
\hline & 418 & 19.9 & - & - & - & - & ${ }^{1} .64$ & 268 & 2.0 \\
\hline \multirow[t]{5}{*}{ GRC-1 } & 392 & 23.9 & 140 & 101 & 236 & 247 & .63 & 247 & 40.0 \\
\hline & 557 & 25.4 & - & - & - & 350 & .63 & 350 & 49.1 \\
\hline & 811 & 14.8 & - & - & - & - & ${ }^{1} .64$ & 519 & 74.2 \\
\hline & 809 & 7.3 & - & - & - & - & ${ }^{1} .64$ & 518 & e2.8 \\
\hline & 885 & 3.3 & - & - & - & - & ${ }^{1} .64$ & 566 & e1.5 \\
\hline \multirow[t]{3}{*}{ GRC-2 } & 393 & 26.4 & - & - & - & - & ${ }^{1} .64$ & 252 & 38.7 \\
\hline & 560 & 25.8 & - & - & - & - & ${ }^{1} .64$ & 358 & - \\
\hline & 811 & 15.0 & - & - & - & - & .64 & 519 & - \\
\hline \multirow[t]{2}{*}{ GRC-3 } & 422 & 23.4 & - & - & - & 271 & .64 & 271 & 8.8 \\
\hline & 855 & 15.8 & - & - & - & - & ${ }^{1} .64$ & 547 & 19.2 \\
\hline TC-1 & 556 & 25.5 & - & - & - & - & ${ }^{1} .64$ & 356 & 25.0 \\
\hline DCH-1 & 455 & - & - & - & - & 303 & .67 & 303 & .1 \\
\hline DCH-2 & 463 & 26.6 & - & - & - & - & ${ }^{1} .64$ & 296 & .1 \\
\hline DCH-3 & 833 & 15.0 & - & - & - & - & ${ }^{1} .64$ & 533 & .4 \\
\hline DCH-4 & 841 & 14.0 & - & - & - & - & ${ }^{1} .64$ & 538 & 1.1 \\
\hline \multirow[t]{3}{*}{ DRN-1 } & 505 & 20.2 & - & - & - & 290 & .57 & 290 & .1 \\
\hline & 643 & 20.8 & - & - & - & - & ${ }^{2} .60$ & 386 & e. 1 \\
\hline & 982 & 16.3 & - & - & - & - & ${ }^{2} .60$ & 589 & 3.5 \\
\hline \multirow[t]{5}{*}{ DRN-2 } & 561 & 21.0 & - & - & - & - & ${ }^{2} .60$ & 337 & .9 \\
\hline & 759 & 28.1 & - & - & - & - & ${ }^{2} .60$ & 455 & 3.7 \\
\hline & 1,550 & 17.5 & - & - & - & - & ${ }^{2} .60$ & 930 & 2.5 \\
\hline & 5,970 & 2.5 & - & - & - & - & ${ }^{3} .95$ & 5,670 & .6 \\
\hline & 6,220 & 9.6 & - & - & - & - & ${ }^{3} .95$ & 5,910 & .8 \\
\hline SD-1 & 824 & - & - & - & - & - & ${ }^{1} .64$ & 527 & 4.6 \\
\hline \multirow[t]{2}{*}{ WS-1 } & 644 & 28.0 & - & - & - & - & ${ }^{2} .60$ & 386 & $<.1$ \\
\hline & 827 & 12.7 & - & - & - & - & ${ }^{2} .60$ & 496 & $<.1$ \\
\hline \multirow[t]{4}{*}{ WS-2 } & 2,210 & 21.8 & 1,000 & 227 & 1,730 & 1,930 & .87 & 1,930 & .4 \\
\hline & 700 & 28.0 & - & - & - & - & ${ }^{2} .60$ & 420 & e4.5 \\
\hline & 4,200 & 14.1 & - & - & - & - & ${ }^{3} .95$ & 3,990 & .5 \\
\hline & 4,030 & 7.5 & - & - & - & - & ${ }^{3} .95$ & 3,830 & .2 \\
\hline \multirow[t]{2}{*}{ WS-3 } & 669 & 15.8 & - & - & - & - & ${ }^{2} .60$ & 401 & e. 1 \\
\hline & 4,330 & 20.8 & 2,100 & 365 & 3,670 & 4,120 & .95 & 4,120 & 0.6 \\
\hline
\end{tabular}


Table 2. Properties of water samples collected from water-quality monitoring sites near Green River, Utah-Continued

\begin{tabular}{|c|c|c|c|c|c|c|c|c|}
\hline $\begin{array}{c}\text { Site } \\
\text { identifier } \\
\text { (see } \\
\text { table 1) }\end{array}$ & $\begin{array}{c}\text { U.S. } \\
\text { Geological } \\
\text { Survey } \\
\text { site } \\
\text { identification } \\
\text { number }\end{array}$ & $\begin{array}{l}\text { Site } \\
\text { type }\end{array}$ & $\begin{array}{c}\text { Sample } \\
\text { date }\end{array}$ & $\begin{array}{c}\text { Sample } \\
\text { time }\end{array}$ & $\begin{array}{c}\text { Water level, } \\
\text { below land } \\
\text { surface } \\
\text { (feet) }\end{array}$ & $\begin{array}{l}\text { Discharge, } \\
\text { instan- } \\
\text { taneous } \\
\left(\mathrm{ft}^{3} / \mathrm{s}\right)\end{array}$ & $\begin{array}{c}\text { pH, water, } \\
\text { unfiltered, } \\
\text { laboratory } \\
\text { (standard } \\
\text { units) }\end{array}$ & $\begin{array}{c}\text { Specific } \\
\text { conduc- } \\
\text { tance, } \\
\text { water, } \\
\text { unfiltered, } \\
\text { laboratory } \\
\text { ( } \mu \mathrm{S} / \mathrm{cm} \text { at } \\
25^{\circ} \mathrm{C} \text { ) }\end{array}$ \\
\hline \multirow{4}{*}{\multicolumn{2}{|c|}{ WS-3-Continued }} & & 07/13/04 & 1500 & NA & .01 & - & - \\
\hline & & & 09/21/04 & 1250 & NA & .03 & - & - \\
\hline & & & $02 / 10 / 05$ & 1315 & NA & .01 & - & - \\
\hline & & & $03 / 31 / 05$ & 1730 & NA & .01 & - & - \\
\hline \multirow[t]{5}{*}{ WS-4 } & 390146110090901 & drain & 03/14/04 & 0930 & NA & e1 & - & - \\
\hline & & & 06/08/04 & 1645 & NA & 7.5 & - & - \\
\hline & & & 07/14/04 & 0753 & NA & 2 & - & - \\
\hline & & & 09/21/04 & 1500 & NA & 5 & - & - \\
\hline & & & 02/10/05 & 1410 & NA & .02 & 7.6 & 4,000 \\
\hline SP-1 & 390313110084001 & seep & 06/07/04 & 1915 & NA & $<.01$ & - & - \\
\hline SP-2 & 390612110070401 & seep & 08/17/04 & 1225 & NA & $<.01$ & 7.4 & 4,670 \\
\hline \multirow[t]{4}{*}{ SP-3 } & 390233110090401 & seep & 06/08/04 & 1610 & NA & $<.01$ & - & - \\
\hline & & & 07/07/04 & 1500 & NA & $<.01$ & - & - \\
\hline & & & 07/13/04 & 1046 & NA & $<.01$ & - & - \\
\hline & & & 09/21/04 & 1300 & NA & $<.01$ & - & 一 \\
\hline \multirow[t]{2}{*}{ SP-4 } & 390608110070602 & seep & 08/17/04 & 1300 & NA & e1 & - & - \\
\hline & & & 09/23/04 & 1300 & NA & $<.1$ & - & - \\
\hline SP-5 & 390311110083601 & seep & $09 / 21 / 04$ & 1125 & NA & $<.01$ & - & 一 \\
\hline SP-6 & 385958110082301 & seep & 09/22/04 & 1110 & NA & $<.1$ & - & - \\
\hline \multirow[t]{4}{*}{$\mathrm{W}-1$} & 385947110083301 & well & 03/14/04 & 1000 & 7.00 & NA & - & - \\
\hline & & & 06/09/04 & 1130 & 9.20 & NA & 7.9 & 1,590 \\
\hline & & & 07/07/04 & 0800 & 9.92 & NA & - & 一 \\
\hline & & & 02/10/05 & 1030 & dry & NA & - & 一 \\
\hline \multirow[t]{4}{*}{$\mathrm{W}-2$} & 385948110083601 & well & 06/09/04 & 1030 & 9.16 & NA & - & - \\
\hline & & & 07/07/04 & 0810 & 9.87 & NA & - & 一 \\
\hline & & & $09 / 22 / 04$ & 1708 & 10.90 & NA & - & - \\
\hline & & & 02/10/05 & 1023 & 10.74 & NA & - & - \\
\hline \multirow[t]{4}{*}{$\mathrm{W}-3$} & 385958110082401 & well & 03/14/04 & 1100 & - & NA & - & 一 \\
\hline & & & 06/08/04 & 1720 & 6.77 & NA & - & 一 \\
\hline & & & $09 / 22 / 04$ & 1106 & 4.51 & NA & - & - \\
\hline & & & 02/10/05 & 1503 & 7.73 & NA & - & 一 \\
\hline \multirow[t]{3}{*}{ W-4 } & 385958110082601 & well & 06/08/04 & 1740 & 6.16 & NA & - & - \\
\hline & & & 09/22/04 & 1054 & 6.16 & NA & - & 一 \\
\hline & & & $02 / 10 / 05$ & 1500 & 8.45 & NA & - & - \\
\hline W-5 & 390238110093001 & well & 07/07/04 & 1000 & 4.25 & NA & - & 一 \\
\hline
\end{tabular}


Table 2. Properties of water samples collected from water-quality monitoring sites near Green River, Utah-Continued

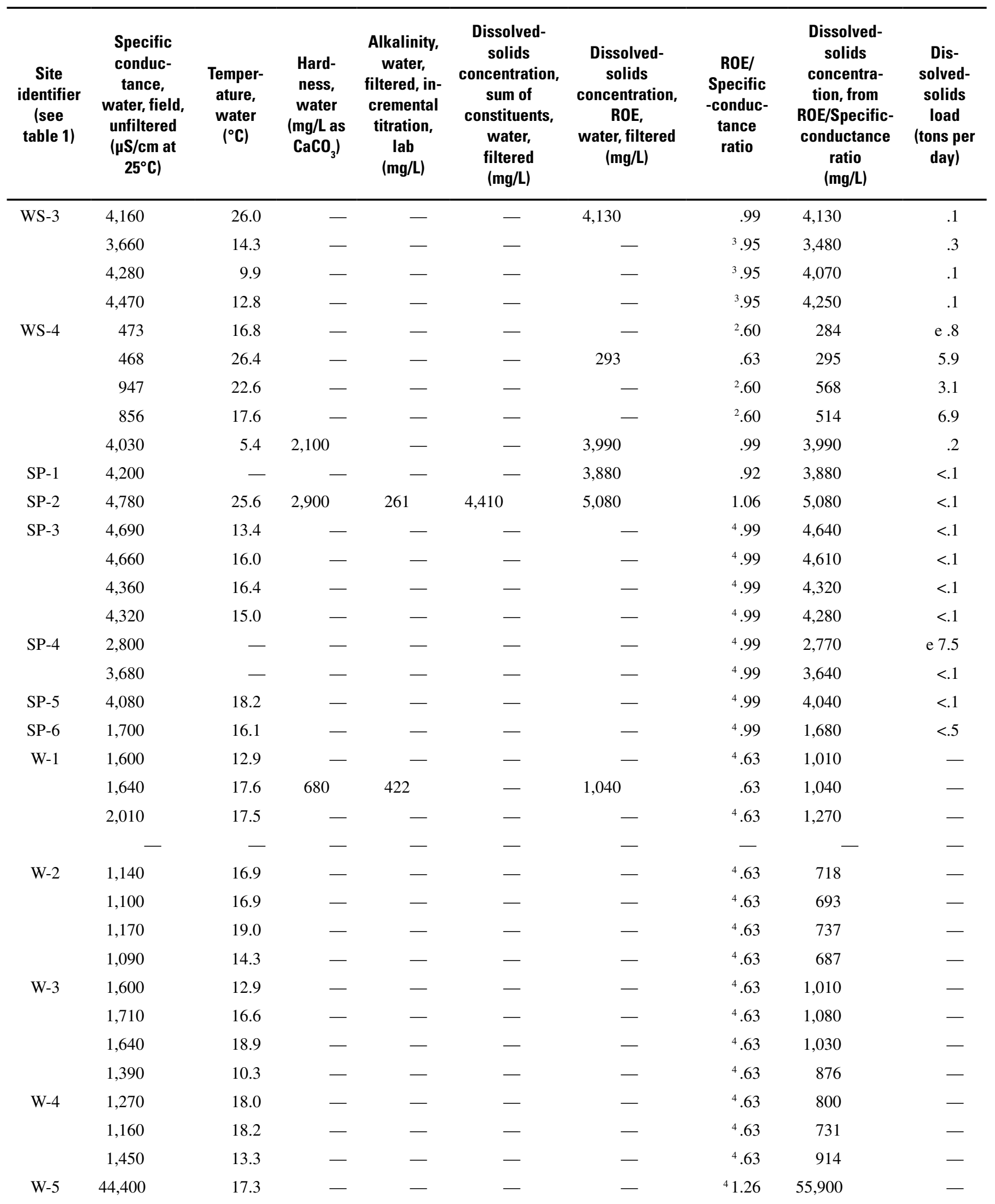


Table 2. Properties of water samples collected from water-quality monitoring sites near Green River, Utah-Continued

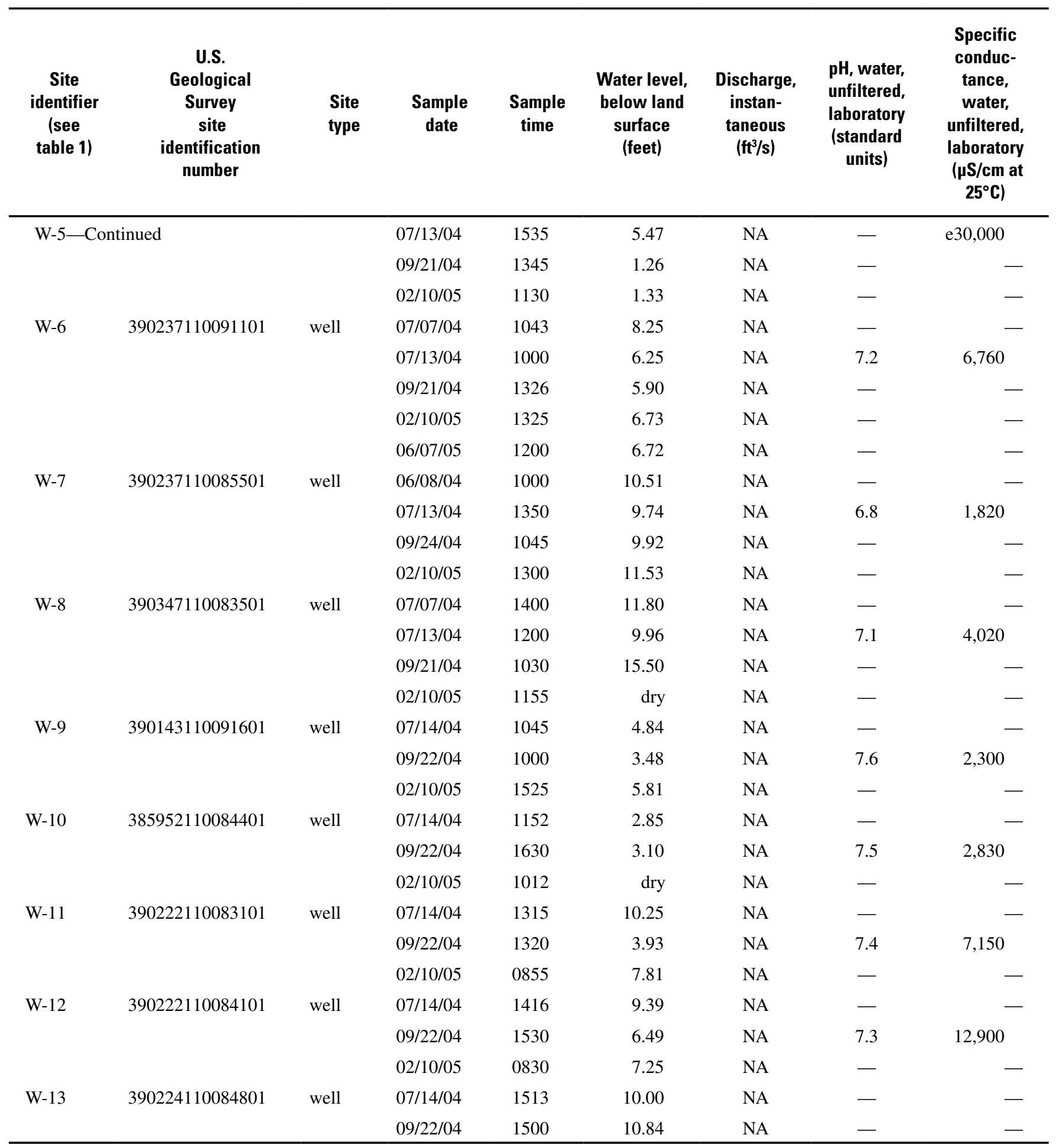

${ }^{1}$ Dissolved-solids/specific-conductance ratio is average of all calculated ratios for canal and river samples.

${ }^{2}$ Dissolved-solids/specific-conductance ratio is average of calculated coefficients for tailwater drains.

${ }^{3}$ Dissolved-solids/specific-conductance ratio is average of calculated coefficients for base-flow drains.

${ }^{4}$ Dissolved-solids/specific-conductance ratio is average of calculated ratios for this site or site type. 
Table 2. Properties of water samples collected from water-quality monitoring sites near Green River, Utah-Continued

\begin{tabular}{|c|c|c|c|c|c|c|c|c|c|}
\hline $\begin{array}{c}\text { Site } \\
\text { identifier } \\
\text { (see } \\
\text { table 1) }\end{array}$ & $\begin{array}{c}\text { Specific } \\
\text { conduc- } \\
\text { tance, } \\
\text { water, field, } \\
\text { unfiltered } \\
(\mu \mathrm{S} / \mathrm{cm} \text { at } \\
\left.25^{\circ} \mathrm{C}\right)\end{array}$ & $\begin{array}{c}\text { Temper- } \\
\text { ature, } \\
\text { water } \\
\left({ }^{\circ} \mathrm{C}\right)\end{array}$ & $\begin{array}{c}\text { Hard- } \\
\text { ness, } \\
\text { water } \\
(\mathrm{mg} / \mathrm{L} \text { as } \\
\left.\mathrm{CaCO}_{3}\right)\end{array}$ & $\begin{array}{l}\text { Alkalinity, } \\
\text { water, } \\
\text { filtered, in- } \\
\text { cremental } \\
\text { titration, } \\
\text { lab } \\
\text { (mg/L) }\end{array}$ & $\begin{array}{l}\text { Dissolved- } \\
\text { solids } \\
\text { concentration, } \\
\text { sum of } \\
\text { constituents, } \\
\text { water, } \\
\text { filtered } \\
\text { (mg/L) }\end{array}$ & $\begin{array}{c}\text { Dissolved- } \\
\text { solids } \\
\text { concentration, } \\
\text { ROE, } \\
\text { water, filtered } \\
\text { (mg/L) }\end{array}$ & $\begin{array}{c}\text { ROE/ } \\
\text { Specific } \\
\text {-conduc- } \\
\text { tance } \\
\text { ratio }\end{array}$ & $\begin{array}{c}\text { Dissolved- } \\
\text { solids } \\
\text { concentra- } \\
\text { tion, from } \\
\text { ROE/Specific- } \\
\text { conductance } \\
\text { ratio } \\
\text { (mg/L) }\end{array}$ & $\begin{array}{l}\text { Dis- } \\
\text { solved- } \\
\text { solids } \\
\text { load } \\
\text { (tons per } \\
\text { day) }\end{array}$ \\
\hline \multirow[t]{3}{*}{ W-5 } & 38,400 & - & - & - & - & 48,500 & 1.26 & 48,400 & - \\
\hline & 32,400 & 18.1 & - & - & - & - & ${ }^{4} 1.26$ & 40,800 & - \\
\hline & 37,600 & 9.2 & - & - & - & - & ${ }^{4} 1.26$ & 47,400 & - \\
\hline \multirow[t]{5}{*}{ W-6 } & 8,900 & - & - & - & - & - & ${ }^{4} .95$ & 8,460 & - \\
\hline & 7,710 & 13.9 & 2,800 & 460 & 6,810 & 7,320 & .95 & 7,320 & - \\
\hline & 6,070 & 16.0 & - & - & - & - & ${ }^{4} .95$ & 5,770 & - \\
\hline & 5,360 & 11.2 & - & - & - & - & ${ }^{4} .95$ & 5,090 & - \\
\hline & 5,560 & 11.2 & - & - & - & - & ${ }^{4} .95$ & 5,280 & - \\
\hline \multirow[t]{4}{*}{ W-7 } & 2,260 & 13.3 & - & - & - & - & ${ }^{4} .81$ & 1,830 & - \\
\hline & 1,850 & 13.4 & 700 & 282 & 1,360 & 1,500 & .80 & 1,480 & - \\
\hline & 1,970 & - & - & - & - & - & ${ }^{4} .81$ & 1,600 & - \\
\hline & 1,670 & 13.8 & - & - & - & - & ${ }^{4} .81$ & 1,350 & - \\
\hline \multirow[t]{4}{*}{ W-8 } & 2,200 & 19.8 & - & - & - & - & ${ }^{4} .98$ & 2,160 & - \\
\hline & 4,380 & 14.5 & 2,600 & 653 & 3,920 & 4,290 & .98 & 4,290 & - \\
\hline & 4,120 & 16.1 & - & - & - & - & ${ }^{4} .98$ & 4,040 & - \\
\hline & - & - & - & - & - & - & - & - & - \\
\hline \multirow[t]{3}{*}{ W-9 } & 1,880 & 17.9 & - & - & - & - & ${ }^{4} .77$ & 1,450 & - \\
\hline & 2,410 & 16.9 & 1,000 & 611 & 1,740 & 1,860 & .77 & 1,860 & - \\
\hline & 2,330 & 9.3 & - & - & - & - & ${ }^{4} .77$ & 1,790 & - \\
\hline \multirow[t]{3}{*}{ W-10 } & 2,620 & 20.2 & - & - & - & - & ${ }^{4} .79$ & 2,070 & - \\
\hline & 2,930 & - & 1,000 & 524 & 2,130 & 2,310 & .79 & 2,310 & - \\
\hline & - & - & - & - & - & - & ${ }^{4} .79$ & - & - \\
\hline \multirow[t]{3}{*}{ W-11 } & 2,080 & 17.0 & - & - & - & - & ${ }^{4} .88$ & 1,830 & - \\
\hline & 7,430 & 17.2 & 2,700 & 1,220 & 6,230 & 6,510 & .88 & 6,510 & - \\
\hline & 6,260 & 10.0 & - & - & - & - & ${ }^{4} .88$ & 5,510 & - \\
\hline \multirow[t]{3}{*}{ W-12 } & 12,100 & 18.0 & - & - & - & - & ${ }^{4} .94$ & 11,400 & - \\
\hline & 13,200 & 16.9 & 3,300 & 1,180 & 11,900 & 12,400 & .94 & 12,400 & - \\
\hline & 9,070 & 10.5 & - & - & - & - & ${ }^{4} .94$ & 8,530 & - \\
\hline \multirow[t]{2}{*}{ W-13 } & 1,300 & 18.0 & - & - & - & - & ${ }^{4} .63$ & 819 & - \\
\hline & 1,690 & - & - & - & - & - & ${ }^{4} .63$ & 1,060 & - \\
\hline
\end{tabular}




\section{Hydrology and water quality in selected areas in and near the Green River, Utah, 2004-05}

Table 3. Concentration of major ions in water samples collected from water-quality monitoring sites near Green River, Utah

[mg/L, milligrams per liter; $<$, less than]

\begin{tabular}{|c|c|c|c|c|c|c|}
\hline $\begin{array}{c}\text { Site } \\
\text { identifier } \\
\text { (see table 1) }\end{array}$ & $\begin{array}{c}\text { U.S. Geological } \\
\text { Survey site } \\
\text { identification } \\
\text { number } \\
\end{array}$ & Site type & $\begin{array}{c}\text { Sample } \\
\text { date }\end{array}$ & $\begin{array}{c}\text { Sample } \\
\text { time }\end{array}$ & $\begin{array}{c}\text { Calcium, } \\
\text { water, } \\
\text { filtered } \\
(\mathrm{mg} / \mathrm{L}) \\
\end{array}$ & $\begin{array}{c}\text { Magnesium, } \\
\text { water, } \\
\text { filtered } \\
\text { (mg/L) }\end{array}$ \\
\hline \multirow[t]{5}{*}{ GR-1 } & 390608110070601 & river & 08/17/04 & 1115 & 58 & 26 \\
\hline & & & 09/23/04 & 1200 & 62 & 27 \\
\hline & & & $10 / 14 / 04$ & 1215 & 53 & 21 \\
\hline & & & $11 / 16 / 04$ & 1340 & 61 & 27 \\
\hline & & & $12 / 15 / 04$ & 1530 & 67 & 30 \\
\hline \multirow[t]{4}{*}{ GR-2 } & 09315000 & river & 08/17/04 & 1700 & 59 & 26 \\
\hline & & & 09/23/04 & 1615 & 63 & 28 \\
\hline & & & $10 / 14 / 04$ & 1550 & 54 & 21 \\
\hline & & & $11 / 16 / 04$ & 1605 & 63 & 27 \\
\hline GRC-1 & 390428110084901 & canal & 06/07/04 & 1445 & 36 & 13 \\
\hline WS-2 & 390313110083801 & drain & 06/07/04 & 1850 & 224 & 108 \\
\hline WS-3 & 390233110090001 & drain & 06/08/04 & 1600 & 562 & 181 \\
\hline WS-4 & 390146110090901 & drain & $02 / 10 / 05$ & 1410 & 520 & 204 \\
\hline SP-2 & 390612110070401 & seep & 08/17/04 & 1225 & 529 & 388 \\
\hline $\mathrm{W}-1$ & 385947110083301 & well & 06/09/04 & 1130 & 158 & 69 \\
\hline W-6 & 390237110091101 & well & 07/13/04 & 1000 & 350 & 479 \\
\hline W-7 & 390237110085501 & well & 07/13/04 & 1350 & 125 & 94 \\
\hline W-8 & 390347110083501 & well & 07/13/04 & 1200 & 657 & 231 \\
\hline W-9 & 390143110091601 & well & $09 / 22 / 04$ & 1000 & 235 & 102 \\
\hline $\mathrm{W}-10$ & 385952110084401 & well & 09/22/04 & 1630 & 218 & 120 \\
\hline $\mathrm{W}-11$ & 390222110083101 & well & $09 / 22 / 04$ & 1320 & 506 & 347 \\
\hline $\mathrm{W}-12$ & 390222110084101 & well & 09/22/04 & 1530 & 542 & 469 \\
\hline
\end{tabular}


Table 3. Concentration of major ions in water samples collected from water-quality monitoring sites near Green River, Utah—Continued

\begin{tabular}{lcccccc}
\hline $\begin{array}{c}\text { Site identifier } \\
\text { (see table 1) }\end{array}$ & $\begin{array}{c}\text { Potassium, } \\
\text { water, } \\
\text { filtered } \\
\text { (mg/L) }\end{array}$ & $\begin{array}{c}\text { Sodium, } \\
\text { water, } \\
\text { filtered } \\
\text { (mg/L) }\end{array}$ & $\begin{array}{c}\text { Chloride, } \\
\text { water, } \\
\text { filtered } \\
\text { (mg/L) }\end{array}$ & $\begin{array}{c}\text { Fluoride, } \\
\text { water, } \\
\text { filtered } \\
\text { (mg/L) }\end{array}$ & $\begin{array}{c}\text { Silica, } \\
\text { water, } \\
\text { filtered } \\
\text { (mg/L) }\end{array}$ & $\begin{array}{r}\text { Sulfate, } \\
\text { water, } \\
\text { filtered } \\
\text { (mg/L) }\end{array}$ \\
\hline GR-1 & 3.5 & 70 & 29 & 0.4 & 4.5 & 196 \\
& 3.2 & 79 & 28 & .4 & 3.4 & 218 \\
& 2.5 & 51 & 19 & .3 & 6.1 & 148 \\
& 2.8 & 83 & 27 & .4 & 8.5 & 220 \\
GR-2 & 2.5 & 68 & 26 & .3 & 7.3 & 196 \\
& 3.7 & 69 & 29 & .4 & 4.5 & 202 \\
& 3.3 & 79 & 30 & .4 & 3.6 & 224 \\
GRC-1 & 2.5 & 53 & 20 & .3 & 5.9 & 151 \\
WS-2 & 3.0 & 83 & 27 & .4 & 8.5 & 220 \\
WS-3 & 1.7 & 28 & 9.7 & .2 & 7.4 & 81 \\
WS-4 & 4.3 & 156 & 35 & .3 & 13 & 1,050 \\
SP-2 & 6.3 & 359 & 119 & .3 & 19 & 2,200 \\
W-1 & 6.0 & 369 & 66 & .2 & 18 & 2,180 \\
W-6 & 6.0 & 311 & 46 & .2 & 27 & 2,940 \\
W-7 & 4.2 & 143 & 45 & .5 & 20 & 383 \\
W-8 & 14 & 1,140 & 266 & .8 & 23 & 4,240 \\
W-9 & 21 & 160 & 47 & $<.2$ & 8.0 & 676 \\
W-10 & 9.2 & 268 & 61 & .4 & 28 & 2,270 \\
W-11 & 4.3 & 244 & 59 & .9 & 18 & 711 \\
W-12 & 7.5 & 346 & 146 & .3 & 20 & 955 \\
\hline & 12 & 1,110 & 356 & .8 & 29 & 6,510 \\
\hline
\end{tabular}




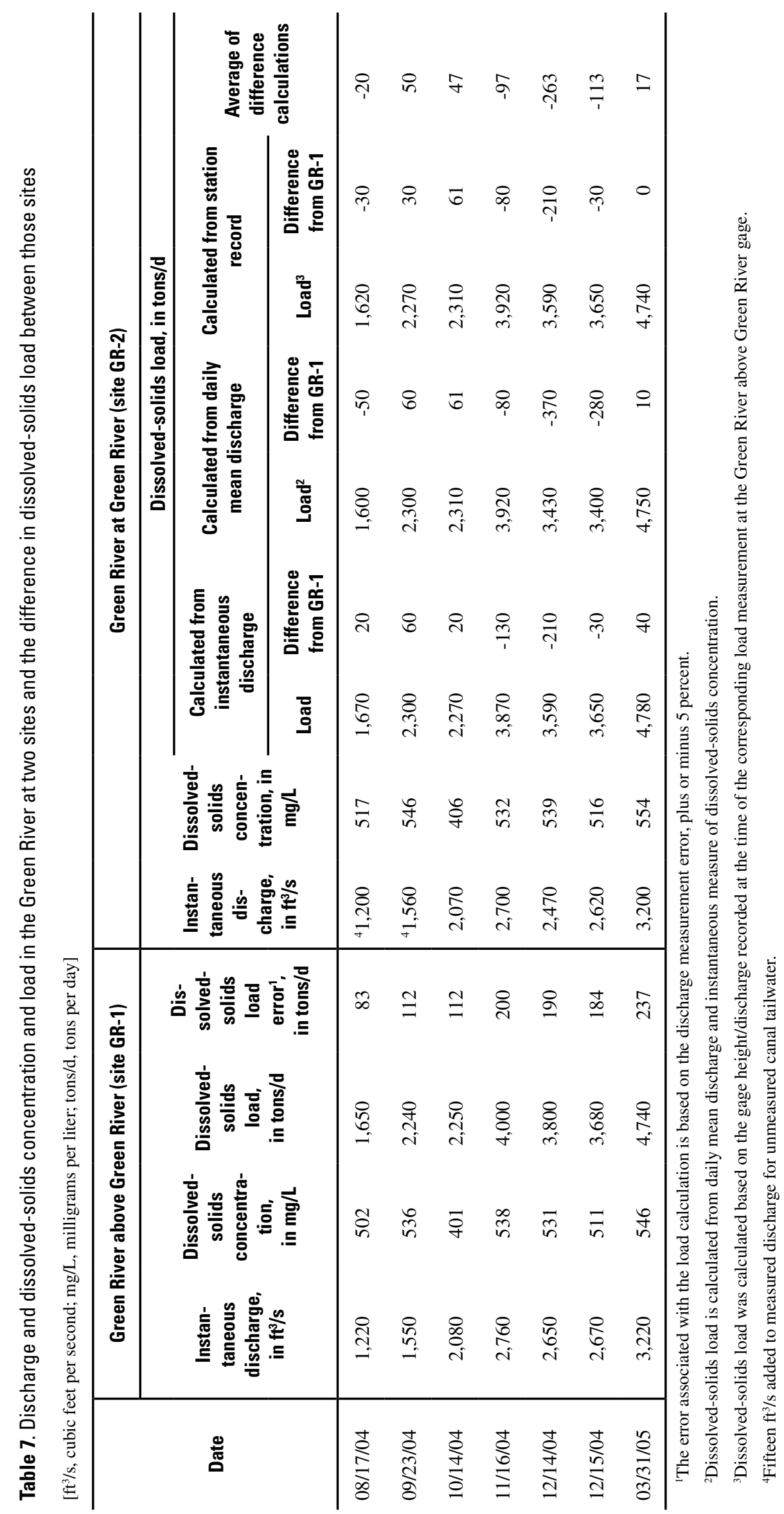




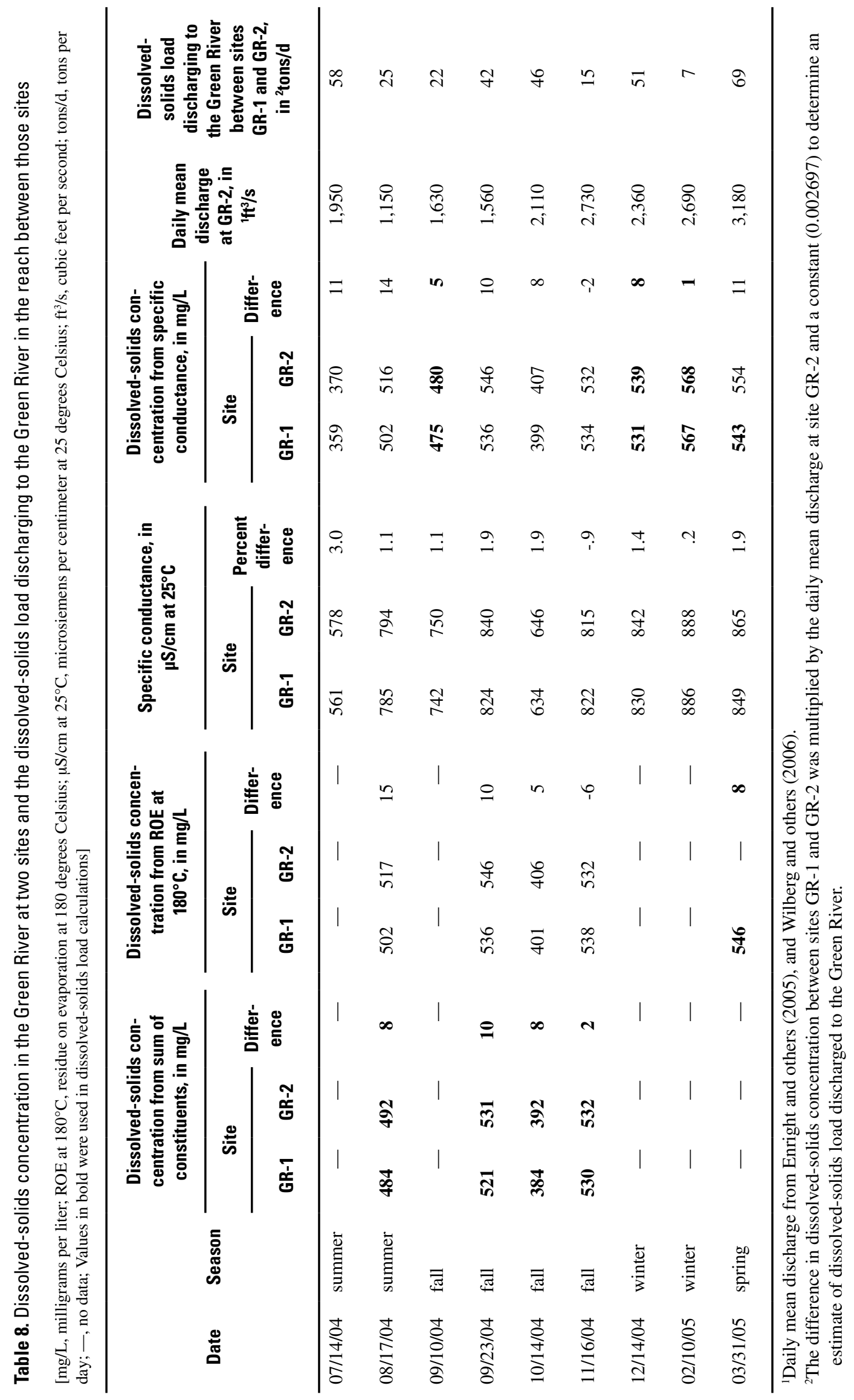


Table 13. Discharge, specific-conductance, and water temperature measurements made on the Thayn and Green River Canals near Green River, Utah

$\left[\mu \mathrm{S} / \mathrm{cm}\right.$, microsiemens per centimeter; ${ }^{\circ} \mathrm{C}$, degrees Celsius; Measurement accuracy: $\mathrm{F}$, fair; $\mathrm{G}$, good; P, poor; —, no data; e, estimated; ft, feet; gal/min, gallons per minute]

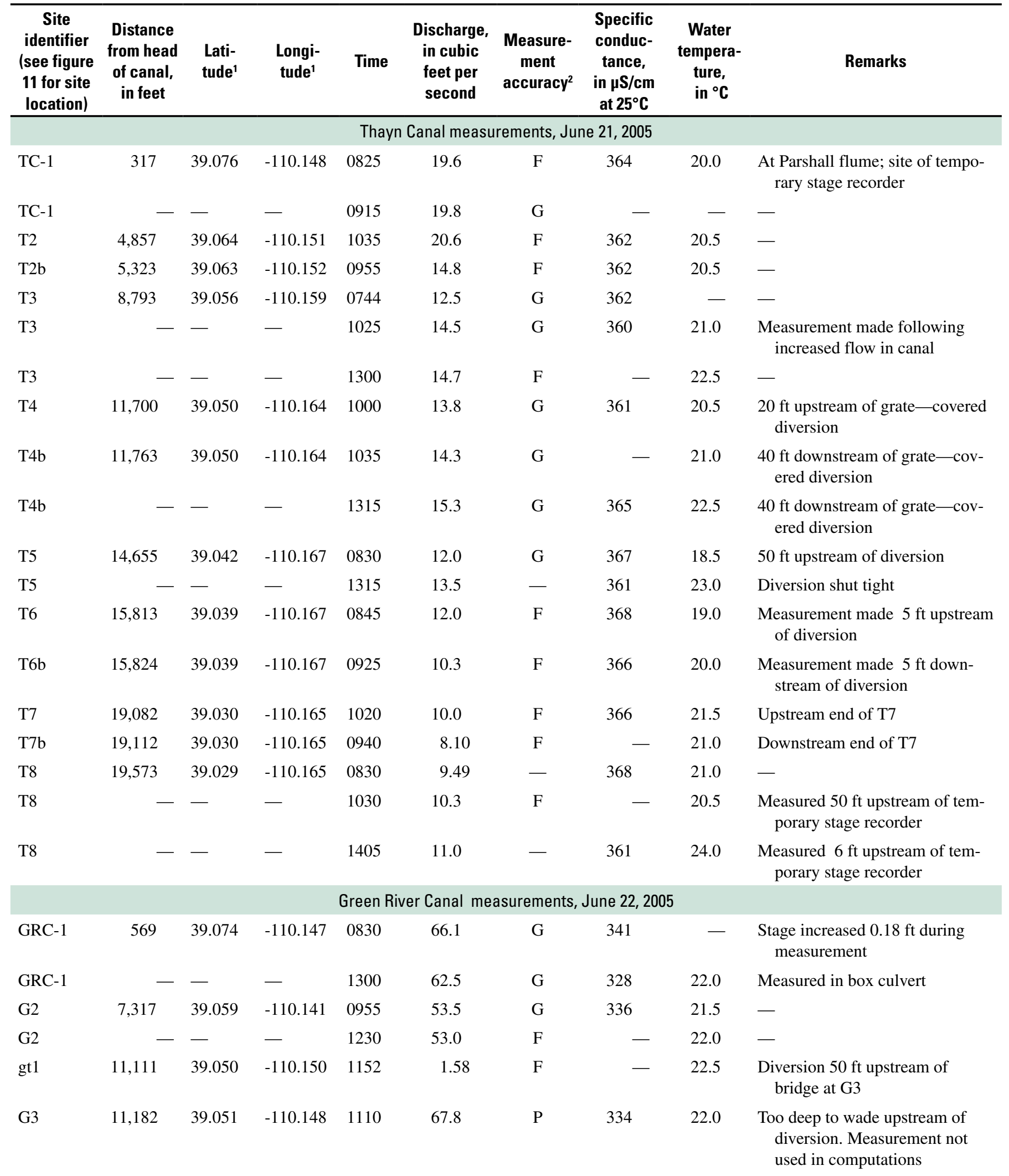


Table 13. Discharge, specific-conductance, and water temperature measurements made on the Thayn and Green River Canals near Green River, Utah-Continued

\begin{tabular}{|c|c|c|c|c|c|c|c|c|c|}
\hline $\begin{array}{c}\text { Site } \\
\text { identifier } \\
\text { (see figure } \\
11 \text { for site } \\
\text { location) }\end{array}$ & $\begin{array}{l}\text { Distance } \\
\text { from head } \\
\text { of canal, } \\
\text { in feet }\end{array}$ & $\begin{array}{l}\text { Lati- } \\
\text { tude }^{1}\end{array}$ & $\begin{array}{l}\text { Longi- } \\
\text { tude }^{1}\end{array}$ & Time & $\begin{array}{c}\text { Discharge, } \\
\text { in cubic } \\
\text { feet per } \\
\text { second }\end{array}$ & $\begin{array}{l}\text { Measure- } \\
\text { ment } \\
\text { accuracy }^{2}\end{array}$ & $\begin{array}{c}\text { Specific } \\
\text { conduc- } \\
\text { tance, } \\
\text { in } \mu \mathrm{S} / \mathrm{cm} \\
\text { at } 25^{\circ} \mathrm{C}\end{array}$ & $\begin{array}{c}\text { Water } \\
\text { tempera- } \\
\text { ture, } \\
\text { in }^{\circ} \mathrm{C}\end{array}$ & Remarks \\
\hline \multicolumn{10}{|c|}{ Green River Canal measurements, June 22, 2005} \\
\hline gt2 & 13,291 & 39.046 & -110.153 & 1315 & $\mathrm{e} 0.4$ & - & - & - & $\begin{array}{c}\text { Open headgate, } 24 \text { sprinklers at } \\
7.5 \mathrm{gal} / \mathrm{min} \text { each (estimated) }\end{array}$ \\
\hline G4 & 15,364 & 39.043 & -110.158 & 0845 & 50.0 & $\mathrm{~F}$ & 344 & 21.0 & $\begin{array}{l}\text { Measured } 15 \mathrm{ft} \text { downstream of } \\
\text { bridge }\end{array}$ \\
\hline G4 & - & - & - & 1330 & 55.4 & $\mathrm{~F}$ & - & - & - \\
\hline gt3 & 19,587 & 39.034 & -110.158 & 0910 & 0.73 & G & - & - & $\begin{array}{l}\text { Measured sand drain just up- } \\
\text { stream of temporary gage at G5 }\end{array}$ \\
\hline gt4 & 21,701 & 39.030 & -110.154 & - & $\mathrm{e} 2$ & - & - & - & $\begin{array}{l}\text { Sand drain upstream of Roscoe } \\
\text { Wash siphon, some debris on } \\
\text { grate }\end{array}$ \\
\hline G6 & 22,275 & 39.028 & -110.152 & 1115 & 48.0 & G & 369 & 21.5 & Measured downstream of siphon \\
\hline G7 & 24,632 & 39.022 & -110.152 & 1345 & 48.5 & - & 361 & 23.0 & Upstream of diversion \\
\hline $\mathrm{gt} 5$ & 24,679 & 39.022 & -110.152 & 0900 & 2.32 & - & - & - & Diversion flows to east \\
\hline gt6 & 26,556 & 39.017 & -110.154 & 1505 & 1.60 & $\mathrm{~F}$ & - & - & $\begin{array}{l}\text { Flows east to river in incised } \\
\text { channel }\end{array}$ \\
\hline G9 & - & - & - & 1200 & 29.6 & - & 365 & - & $\begin{array}{l}\text { Measured at downstream side of } \\
\text { culvert opening }\end{array}$ \\
\hline G10 & 34,138 & 39.002 & -110.161 & 1100 & 24.2 & $\mathrm{~F}$ & 365 & 22.5 & $\begin{array}{l}\text { Measured downstream of diver- } \\
\text { sion }\end{array}$ \\
\hline G10 & - & - & - & 1430 & 27.8 & $\mathrm{P}$ & 359 & 23.0 & - \\
\hline
\end{tabular}

${ }^{1}$ Latitude and longitude are in decimal degrees and projected in North American Datum 83.

${ }^{2}$ Accuracy of discharge measurement: A qualitative evaluation of several factors, such as cross-section composition and stability, velocity uniformity, and channel bed conditions, that could, in the opinion of the streamgager, affect the accuracy of the measurement: G, good, measured discharge is within 5 percent of "true" discharge; F, fair, within 8 percent; P, poor, within 10 percent; e, estimated discharge probably within 25 percent of "true" discharge. 
Table 14. Summary of gains or losses in discharge for specified reaches on the Green River Canal near Green River, Utah, June 22, 2005

[Nd\%, Normalized percent difference: determined for discharge measured at sites along a specified canal reach to compute losses (-) or gains (+). Seepage losses or gains are normalized to the maximum discharge measured at either the upstream site, plus any inflow, or the downstream site, plus any diversions. Maximum discharge is designated as Max Q (us + inflow, ds + diversions). The equation is: Nd\% = ((Qds - (Qus + Qinflow - Qdiversion) / Max Q)) 100 (Wilberg and others, 2001, p. 7-8); Ne\%, Normalized percent error: calculated to determine if a computed loss or gain significantly exceeds error associated with discharge measurements and normalized to the maximum discharge of either the upsteam site, plus any inflow, or the downstream site, plus any diversions in the specified reach. The equation is: (Ne\%) $=(($ aQus + aQds + aQinflow + aQdiversions) / Max Q (us + inflow, ds + diversion)) 100$)($ Wilberg and others, 2001, p. 8); - , no data available]

\begin{tabular}{|c|c|c|c|c|c|c|c|}
\hline \multirow{2}{*}{$\begin{array}{c}\text { Reach } \\
\text { (see figure } 11 \\
\text { for site } \\
\text { location) }\end{array}$} & \multirow[b]{2}{*}{$\begin{array}{l}\text { Length, in } \\
\text { miles }\end{array}$} & \multicolumn{3}{|c|}{ Upstream measurement } & \multicolumn{3}{|c|}{ Downstream measurement } \\
\hline & & Time & $\begin{array}{l}\text { Discharge, } \\
\text { in cubic feet } \\
\text { per second }\end{array}$ & Accuracy $^{2}$ & Time & $\begin{array}{c}\text { Discharge, } \\
\text { in cubic feet } \\
\text { per second }\end{array}$ & Accuracy $^{2}$ \\
\hline GRC-1 to $\mathrm{G} 2$ & 1.28 & 0830 & 66.1 & G & 0955 & 53.5 & $\mathrm{G}$ \\
\hline $\mathrm{G} 2$ to $\mathrm{G} 4$ & 1.52 & 0955 & 53.5 & $\mathrm{G}$ & 0845 & 50.5 & $\mathrm{~F}$ \\
\hline G6 to $\mathrm{G} 7$ & .45 & 1115 & 48 & G & 1345 & 48.5 & $\mathrm{~F}^{4}$ \\
\hline G7 to G8 & .77 & 1345 & 48.5 & $\mathrm{~F}^{4}$ & 0935 & 39.9 & $\mathrm{~F}^{4}$ \\
\hline G8b to $\mathrm{G} 9$ & .75 & 1045 & 31.6 & $\mathrm{~F}^{4}$ & 1200 & 29.6 & $\mathrm{~F}^{4}$ \\
\hline
\end{tabular}

${ }^{1}$ All measured diversions were outflows from the Green River Canal. There were no measured inflows to the canal.

${ }^{2}$ Accuracy of discharge measurement: A qualitative evaluation of several factors, such as cross-section composition and stability, velocity uniformity, and channel bed conditions, that could, in the opinion of the hydrographer, affect the accuracy of the measurement: G, good, measured discharge is within 5 percent of "true" discharge; F, fair, within 8 percent; P, poor, within 10 percent; For a site with two measurements and two accuracy ratings, the average of the two ratings is used. For example, if two measurements were rated $\mathrm{F}$ and $\mathrm{G}$, the average accuracy would be 6.5 percent.

Table 15. Summary of gains or losses in discharge for specified reaches on the Thayn Canal near Green River, Utah, June 21,2005

[Nd\%, Normalized percent difference: determined for discharge measured at sites along a specified canal reach to compute losses (-) or gains (+). Seepage losses or gains are normalized to the maximum discharge measured at either the upstream site, plus any inflow, or the downstream site, plus any diversions. Maximum discharge is designated as Max Q (us + inflow, ds + diversions). The equation is: Nd\% = ((Qds - (Qus + Qinflow - Qdiversion) / Max Q)) 100 (Wilberg and others, 2001, p. 7-8); Ne\%, Normalized percent error: calculated to determine if a computed loss or gain significantly exceeds error associated with discharge measurements and normalized to the maximum discharge of either the upsteam site, plus any inflow, or the downstream site, plus any diversions in the specified reach. The equation is: $(\mathrm{Ne} \%)=((\mathrm{aQus}+\mathrm{aQds}+\mathrm{aQinflow}+\mathrm{aQdiversions}) / \mathrm{Max} \mathrm{Q}$ (us + inflow, ds + diversion $)) \cdot 100)($ Wilberg and others, 2001, p. 8); - , no data available]

\begin{tabular}{|c|c|c|c|c|c|c|c|}
\hline \multirow{2}{*}{$\begin{array}{c}\text { Reach } \\
\text { (see figure } 11 \\
\text { for site } \\
\text { location) }\end{array}$} & \multirow[b]{2}{*}{$\begin{array}{l}\text { Length, in } \\
\text { miles }\end{array}$} & \multicolumn{3}{|c|}{ Upstream measurement } & \multicolumn{3}{|c|}{ Downstream measurement } \\
\hline & & Time & $\begin{array}{l}\text { Discharge, } \\
\text { in cubic feet } \\
\text { per second }\end{array}$ & Accuracy $^{2}$ & Time & $\begin{array}{c}\text { Discharge, } \\
\text { in cubic feet } \\
\text { per second }\end{array}$ & Accuracy $^{2}$ \\
\hline $\mathrm{TC}-1$ to $\mathrm{T} 2$ & 0.86 & 0915 & 19.8 & G & 1035 & 20.6 & $\mathrm{~F}$ \\
\hline $\mathrm{T} 2 \mathrm{~b}$ to $\mathrm{T} 3$ & .66 & 0955 & 14.8 & $\mathrm{~F}$ & 1025 & 14.5 & $\mathrm{G}$ \\
\hline $\mathrm{T} 3$ to $\mathrm{T} 4$ & .55 & 1025 & 14.5 & G & 1000 & 13.8 & G \\
\hline $\mathrm{T} 4 \mathrm{~b}$ to $\mathrm{T} 5$ & .55 & 1315 & 15.3 & G & 1315 & 13.5 & $\mathrm{G}$ \\
\hline $\mathrm{T} 5$ to $\mathrm{T} 6$ & .22 & 1315 & 13.5 & $\mathrm{G}$ & 0845 & 12.0 & $\mathrm{~F}$ \\
\hline T6b to $\mathrm{T} 7$ & .62 & 0925 & 10.3 & $\mathrm{~F}$ & 1020 & 10.0 & $\mathrm{~F}$ \\
\hline $\mathrm{T} 7 \mathrm{~b}$ to $\mathrm{T} 8$ & .08 & 0940 & 8.1 & $\mathrm{~F}$ & 0830 & 9.5 & $\mathrm{~F}$ \\
\hline
\end{tabular}

${ }^{1}$ All diversion discharge values are calculated from measurements in the Thayn Canal above and below outflows. There were no measured inflows to the canal.

${ }^{2}$ Accuracy of discharge measurement: A qualitative evaluation of several factors, such as cross-section composition and stability, velocity uniformity, and channel bed conditions, that could, in the opinion of the streamgager, affect the accuracy of the measurement: G, good, measured discharge is within 5 percent of "true" discharge; F, fair, within 8 percent; P, poor, within 10 percent; e, estimated discharge probably within 25 percent of "true" discharge. For a site with two measurements and two accuracy ratings, the average of the two ratings is used. For example, if two measurements were rated $\mathrm{F}$ and $\mathrm{G}$, the average accuracy would be 6.5 percent. 
Table 14. Summary of gains or losses in discharge for specified reaches on the Green River Canal near Green River, Utah, June 22, 2005-Continued

\begin{tabular}{|c|c|c|c|c|c|c|c|c|}
\hline \multirow{2}{*}{$\begin{array}{c}\text { Reach } \\
\text { (see figure } 11 \\
\text { for site } \\
\text { location) }\end{array}$} & \multicolumn{3}{|c|}{ Diversion measurement ${ }^{1}$} & \multicolumn{5}{|c|}{ Seepage } \\
\hline & Time & $\begin{array}{c}\text { Discharge, } \\
\text { in cubic feet } \\
\text { per second }\end{array}$ & Accuracy $^{2}$ & $\begin{array}{c}\text { Gain or loss, } \\
\text { in cubic feet } \\
\text { per second }\end{array}$ & $\begin{array}{c}\text { Gain or loss, } \\
\text { in acre-feet } \\
\text { per day }\end{array}$ & $\mathbf{N d} \%$ & $\mathrm{Ne} \%$ & $\begin{array}{c}\text { Significant } \\
\text { loss }(-) \text { or } \\
\text { gain }(+)^{3}\end{array}$ \\
\hline GRC-1 to G2 & - & none measured & - & -12.6 & -25.0 & -19.1 & 9.0 & $(-)$ \\
\hline $\mathrm{G} 2$ to $\mathrm{G} 4$ & various & 1.98 & F,P & -1.0 & -2.0 & -1.9 & 13.8 & none \\
\hline G4 to G5 & - & none measured & - & -4.4 & -8.7 & -8.7 & 12.6 & none \\
\hline G5 to G6 & various & 2.7 & $\mathrm{G}, \mathrm{P}$ & .3 & 6 & .7 & 15.7 & none \\
\hline G6 to $\mathrm{G} 7$ & - & none measured & - & .5 & 1.0 & 1.0 & 15.0 & none \\
\hline $\mathrm{G} 7$ to $\mathrm{G} 8$ & various & 3.9 & F,P & -4.7 & -9.3 & -9.6 & 19.0 & none \\
\hline G8b to $\mathrm{G} 9$ & - & none measured & - & -2.0 & -4.0 & -6.3 & 19.4 & none \\
\hline
\end{tabular}

${ }^{3} \mathrm{~A}$ computed loss or gain is considered significant when the normalized percent difference $(\mathrm{Nd} \%)$ is equal to or greater than the normalized percent error $(\mathrm{Ne} \%)$.

${ }^{4}$ Measurements that were not rated by the hydrographer were assigned a rating of "fair."

Table 15. Summary of gains or losses in discharge for specified reaches on the Thayn Canal near Green River, Utah, June 21, 2005-Continued

\begin{tabular}{|c|c|c|c|c|c|c|c|c|}
\hline \multirow{2}{*}{$\begin{array}{c}\text { Reach } \\
\text { (see figure } 11 \\
\text { for site } \\
\text { location) }\end{array}$} & \multicolumn{3}{|c|}{ Diversions $^{1}$} & \multicolumn{5}{|c|}{ Seepage } \\
\hline & Time & $\begin{array}{l}\text { Discharge, in } \\
\text { cubic feet } \\
\text { per second }\end{array}$ & Accuracy $^{2}$ & $\begin{array}{c}\text { Gain or loss, } \\
\text { in cubic feet } \\
\text { per second }\end{array}$ & $\begin{array}{c}\text { Gain or loss, } \\
\text { in acre-feet } \\
\text { per day }\end{array}$ & $\mathbf{N d} \%$ & $\mathrm{Ne} \%$ & $\begin{array}{c}\text { Significant } \\
\text { loss }(-) \text { or } \\
\text { gain }(+)^{3}\end{array}$ \\
\hline $\mathrm{TC}-1$ to $\mathrm{T} 2$ & - & none measured & - & -0.8 & 1.6 & 3.9 & 12.8 & none \\
\hline $\mathrm{T} 2 \mathrm{~b}$ to $\mathrm{T} 3$ & - & none measured & - & -.3 & -.6 & -2.0 & 12.9 & none \\
\hline $\mathrm{T} 3$ to $\mathrm{T} 4$ & - & none measured & - & -.7 & -1.4 & -4.8 & 9.8 & none \\
\hline $\mathrm{T} 4 \mathrm{~b}$ to $\mathrm{T} 5$ & - & none measured & - & -2.2 & -4.4 & -11.8 & 9.4 & $(-)$ \\
\hline T5 to $\mathrm{T} 6$ & - & none measured & - & -1.5 & -3.0 & -11.1 & 12.1 & none \\
\hline T6bto T7 & - & none measured & - & -.3 & -.6 & -2.9 & 15.8 & none \\
\hline $\mathrm{T} 7 \mathrm{~b}$ to $\mathrm{T} 8$ & - & none measured & - & 1.4 & 2.8 & 14.7 & 14.8 & none \\
\hline
\end{tabular}

${ }^{3} \mathrm{~A}$ computed loss or gain is considered significant when the normalized percent difference $(\mathrm{Nd} \%)$ is equal to or greater than the normalized percent error $(\mathrm{Ne} \%)$. 
42 Hydrology and water quality in selected areas in and near the Green River, Utah, 2004-05 


\section{疍}

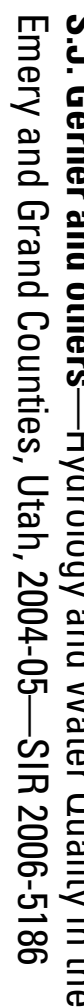

ס

ํㅗㅇ

을

등을

政

I

도음

亭

它离

스을

宁 ฏ.

志

ㅁ

疋

司

Ф

ํㅡㄹ

$\infty$

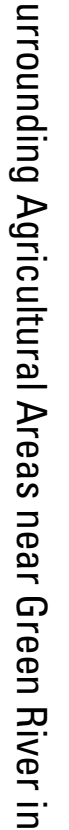

